\title{
Pilot-Scale Grout Production Test with a Simulated Low-Level Waste
}
C. L. Fow
D. H. Mitchell
R. L. Treat
C. R. Hymas

May 1987

Prepared for the U.S. Department of Energy under Contract DE-AC06-76RLO 1830

Pacific Northwest Laboratory Operated for the U.S. Department of Energy by Battelle Memorial Institute 


\section{DISCLAIMER}

This report was prepared as an account of work sponsored by an agency of the United States Government. Neither the United States Government nor any agency thereof, nor Battelle Memorial Institute, nor any of their employees, makes any warranty, expressed or implied, or assumes any legal liability or responsibility for the accuracy, completeness, or usefulness of any information, apparatus, product, or process disclosed, or represents that its use would not infringe privately owned rights. Reference herein to any specific commercial product, process, or service by trade name, trademark, manufacturer, or otherwise, does not necessarily constitute or imply its endorsement, recommendation, or favoring by the United States Government of any agency thereof, or Battelle Memorial Institute. The views and opinions of authors expressed herein do not necessarly state or reflect those of the United States Government or any agency thereof, or Battelle Memorial Institute.

\section{PACIFIC NORTHWEST LABORATORY operated by \\ BATTELLE MEMORIAL INSTITUTE \\ for the \\ UNITED STATES DEPARTMENT OF ENERGY under Contract DE-AC06-76RLO 1830}

\begin{tabular}{|c|c|}
\hline \multicolumn{2}{|c|}{ Printed in the United States of America } \\
\hline \multirow{2}{*}{\multicolumn{2}{|c|}{$\begin{array}{l}\text { Available from } \\
\text { National Technical Information Service }\end{array}$}} \\
\hline & \\
\hline \multicolumn{2}{|c|}{ United States Department of Commerce } \\
\hline \multicolumn{2}{|c|}{5285 Port Royal Road } \\
\hline \multicolumn{2}{|c|}{ Springfield, Virginia 22161} \\
\hline \multirow{2}{*}{\multicolumn{2}{|c|}{$\begin{array}{l}\text { NTIS Price Codes } \\
\text { Microfiche A01 }\end{array}$}} \\
\hline & \\
\hline \multicolumn{2}{|c|}{ Printed Copy } \\
\hline & Price \\
\hline Pages & Codes \\
\hline $001-025$ & $\mathrm{~A} 02$ \\
\hline 026-050 & $\mathrm{A} 03$ \\
\hline 051-075 & A04 \\
\hline 076-100 & A05 \\
\hline $101-125$ & A06 \\
\hline $126-150$ & A07 \\
\hline $151-175$ & $\mathrm{~A} 08$ \\
\hline $176-200$ & A09 \\
\hline $201-225$ & A010 \\
\hline $226-250$ & A011 \\
\hline $251-275$ & A012 \\
\hline $276-300$ & A013 \\
\hline
\end{tabular}


PILOT-SCALE GROUT PRODUCTION TEST WITH A SIMULATED LOW-LEVEL WASTE

C. L. Fow

D. H. Mitchell

R. L. Treat

C. R. Hymas

May 1987

Prepared for the U.S. Department of Energy under Contract DE-AC06-76RL0 1830

Pacific Northwest Laboratory Richland, Washington 99352 
SUMMARY

Plans are underway at the Hanford Site near Richland, Washington, to convert the low-level fraction of radioactive liquid wastes to a grout form for permanent disposal. Grout is a mixture of liquid waste and grout formers, including portland cement, fly ash, and clays. In the plan, the grout slurry is pumped to subsurface concrete vaults on the Hanford Site, where the grout will solidify into large monoliths, thereby immobilizing the waste. A similar disposal concept is beiny planned at the Savannah River Laboratory site. The underyround disposal of grout was conducted at Oak Ridge National Laboratory between 1966 and 1984 (Dole 1985).

Desiyn and construction of grout processing and disposal facilities are underway. The Transportable Grout Facility (TGF), operated by Rockwell Hanford Operations (Rockwell) for the Department of Energy (DOE), is scheduled to yrout Phosphate/Sulfate $N$ Reactor Operations Waste (PSW) in FY 1988. Phosphate/ Sulfate Waste is a blend of two low-level waste streams yenerated at Hanford's $N$ Reactor. (The $N$ Reactor produces special nuclear materials, and its byproduct steam is used to generate electricity.) Other wastes are scheduled to be grouted in subsequent years.

Pacific Northwest Laboratory (PNL) is verifying that Hanford grouts can be safely and efficiently processed. To meet this objective, pilot-scale grout process equipment was installed. The pilot-scale process equipment can produce grout at a rate of up to $25 \%$ of the maximum rate planned for the TGF.

On July 29 and 30, 1986, PNL conducted a pilot-scale grout production test for Rockwell. During the test, 16,000 gallons of simulated nonradioactive PSW were mixed with grout formers to produce 22,000 gallons of PSW grout. The grout was pumped at a nominal rate of $15 \mathrm{gpm}$ ( $\sim 25 \%$ of the nominal production rate planned for the TGF) to a lined and covered trench with a capacity of 30,000 gallons. Emplacement of grout in the trench will permit subsequent evaluation of homogeneity of grout in a large monolith. The production of a 
22,000 -yal monolith in a trench also permitted determination of curing characteristics, reabsorption of separated liquid, degree of cracking, and temperature rise expected with monolithic disposal.

The principal process components--the grout mixer and the yrout pump--are very similar to those planned for the Transportable Grout Facility Equipment (TGE). The pilot-scale test permitted evaluation of the performance of the mixer and pump, their flush requirements, and their reliability. In addition, representatives of the engineering firm commissioned to design and construct the processing equipment modules of the TGF observed the test to gain experience with processing grout.

The test was very successful; major conclusions follow:

- The continuous grout mixer and grout pump performed reliably, producing grout with acceptable properties.

- The adiabatic grout temperature rise was at least $37^{\circ} \mathrm{C}$, and probably nigher.

- The flow angle of grout in the trench averaged $1.5^{\circ}$. A similar flow angle can be expected in the disposal vaults with grouts of the same rheological properties.

- The degree of cracking of grout in the trench was minimal, reducing concern over the effect of additional surface area on the performance assessment of this disposal method.

- The separated liquid that collected on the surface of the grout monolith was totally reabsorbed in 30 days. If the TGF operates under similar conditions (grout rheology and ratio of flush water to grout volume), total reabsorption can be expected.

Analyses of samples of grout, separated liquid, dry blend, and simulated PSW taken during and after the pilot-scale tests were in progress at the time this report was prepared. A future report will discuss the homogeneity of yrout in the monolith and the properties of the samples collected. 


\section{ACKNOWLEDGMENTS}

The authors wish to acknowledge the efforts of the following people for their contributions as operators during the pilot-scale test:

Pacific Northwest Laboratory

D. L. Matuszewski

R. 0. Lokken

P. F. C. Martin

0. G. Huizenga

W. T. Farris

M. A. Reimus

R. S. Hogue

C. J. Mann

Rockwell Hanford Operations

R. S. Snirley

A. R. Tedeschi

S. M. Peterman

R. H. Guymon

Oak Ridge National Laboratory

T. L. Sams

Laboratory, analytical, and planning support before, during, and after the pilot-scale test were led by R. 0. Lokken and P. F. C. Martin. Technical editing of this report was provided by A. H. McMakin. 


\section{CONTENTS}

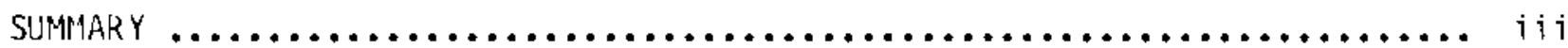

ACXNOWLEDGMENTS $\ldots \ldots \ldots \ldots \ldots \ldots \ldots \ldots \ldots \ldots \ldots \ldots \ldots \ldots \ldots \ldots \ldots \ldots \ldots$

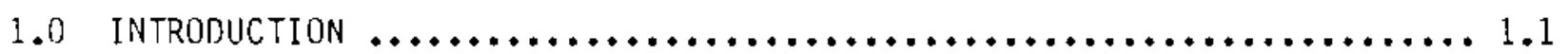

1.1 OBJECTIVES OF THE PILOT-SCALE TEST $\ldots \ldots \ldots \ldots \ldots \ldots \ldots \ldots \ldots \ldots \ldots$

1.2 SCOPE OF PILOT-SCALE TEST $\ldots \ldots \ldots \ldots \ldots \ldots \ldots \ldots \ldots \ldots \ldots \ldots \ldots \ldots$

2.0 DESCRIPTION OF EQUIPMENT AND TRENCH $\ldots \ldots \ldots \ldots \ldots \ldots \ldots \ldots \ldots \ldots \ldots \ldots . \ldots \ldots$

2.1 WASTE SUPPLY $\ldots \ldots \ldots \ldots \ldots \ldots \ldots \ldots \ldots \ldots \ldots \ldots \ldots \ldots \ldots \ldots \ldots \ldots \ldots \ldots \ldots$

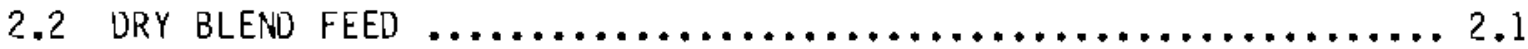

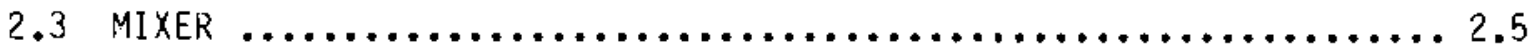

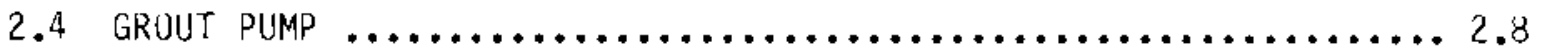

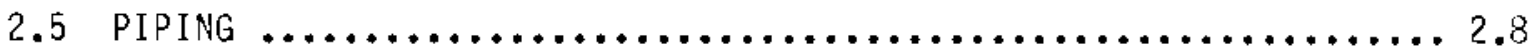

2.6 TRENCH $\ldots \ldots \ldots \ldots \ldots \ldots \ldots \ldots \ldots \ldots \ldots \ldots \ldots \ldots \ldots \ldots \ldots \ldots \ldots \ldots \ldots \ldots \ldots$

2.7 PROCESS INSTRUMENTATION $\ldots \ldots \ldots \ldots \ldots \ldots \ldots \ldots \ldots \ldots \ldots \ldots \ldots \ldots \ldots \ldots \ldots$

2.7.1 Temperature Measurement ........................ 2.14

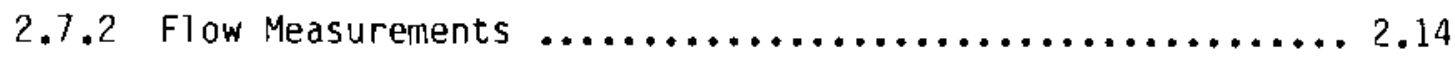

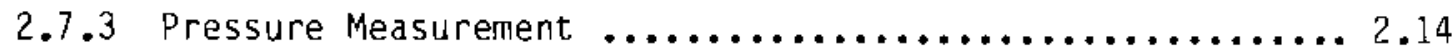

2.7.4 Miscellaneous Measurements $\ldots \ldots \ldots \ldots \ldots \ldots \ldots \ldots \ldots \ldots . . \ldots . \ldots . . \ldots$

3.0 Material PReparation and Sampling Procedures $\ldots \ldots \ldots \ldots \ldots \ldots \ldots \ldots \ldots . . \ldots$

3.1 SYNTHETIC WASTE PREPARATION $\ldots \ldots \ldots \ldots \ldots \ldots \ldots \ldots \ldots \ldots \ldots \ldots \ldots .1$

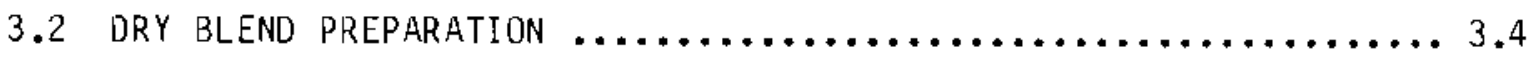

3.3 SAMPLING DURING THE TEST $\ldots \ldots \ldots \ldots \ldots \ldots \ldots \ldots \ldots \ldots \ldots \ldots \ldots \ldots . . \ldots \ldots$

3.3 .1 Grout Core Sampler $\ldots \ldots \ldots \ldots \ldots \ldots \ldots \ldots \ldots \ldots \ldots \ldots \ldots .4$

3.3 .2 Sampling Plans and Tests $\ldots \ldots \ldots \ldots \ldots \ldots \ldots \ldots \ldots \ldots . \ldots \ldots$ 


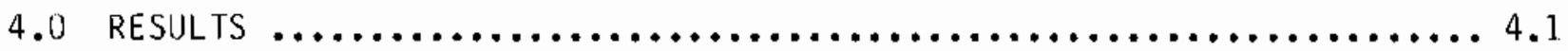

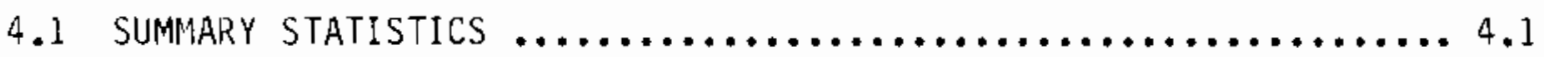

4.2 BEHAVIOR OF GROUT IN THE TRENCH $\ldots \ldots \ldots \ldots \ldots \ldots \ldots \ldots \ldots \ldots \ldots \ldots . \ldots \ldots$

4.2 .1 Flow Angle $\ldots \ldots \ldots \ldots \ldots \ldots \ldots \ldots \ldots \ldots \ldots \ldots \ldots \ldots \ldots . . \ldots \ldots$

4.2 .2 Flow Patterns ............................. 4.4

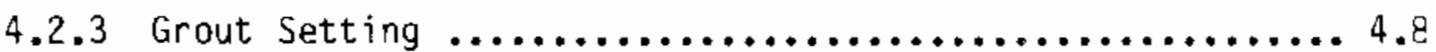

4.2 .4 Separated Liquid $\ldots \ldots \ldots \ldots \ldots \ldots \ldots \ldots \ldots \ldots \ldots \ldots \ldots . \ldots \ldots$

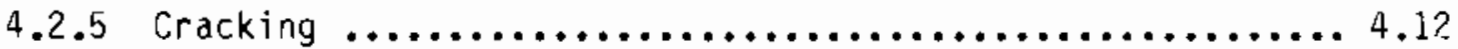

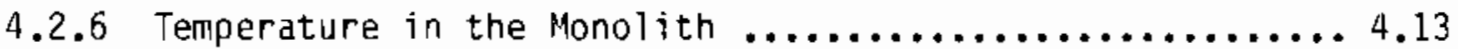

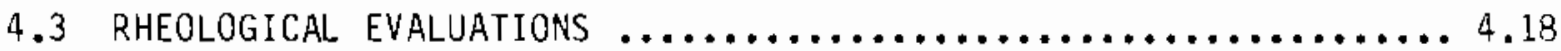

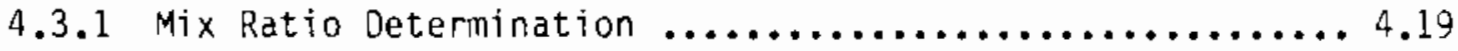

4.3.2 Pilot-Scale Test Rheological Evaluations ............ 4.22

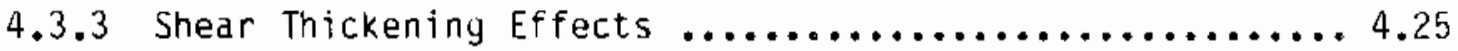

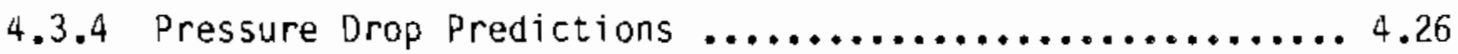

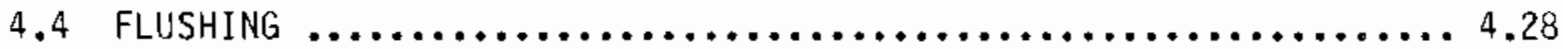

4.4 .1 Mixer $\ldots \ldots \ldots \ldots \ldots \ldots \ldots \ldots \ldots \ldots \ldots \ldots \ldots \ldots \ldots \ldots \ldots \ldots \ldots . \ldots \ldots . \ldots \ldots \ldots$

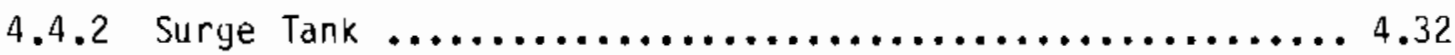

4.4 .3 Pump $\ldots \ldots \ldots \ldots \ldots \ldots \ldots \ldots \ldots \ldots \ldots \ldots \ldots \ldots \ldots \ldots \ldots \ldots \ldots . \ldots . \ldots \ldots \ldots$

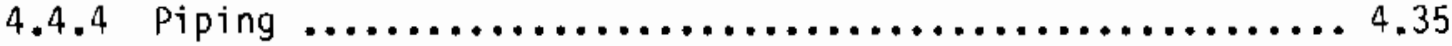

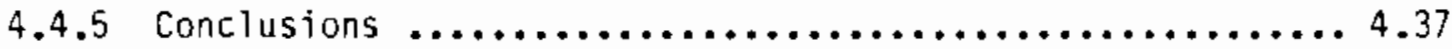

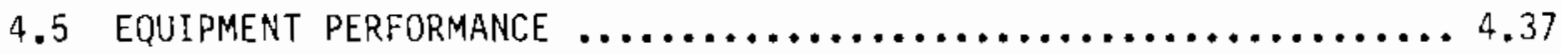

4.5.1 Dry Blend Transfer and Feed System ............... 4.38

4.5 .2 Vibrating Screen $\ldots \ldots \ldots \ldots \ldots \ldots \ldots \ldots \ldots \ldots \ldots \ldots \ldots \ldots . . .40$

4.5 .3 Mixer $\ldots \ldots \ldots \ldots \ldots \ldots \ldots \ldots \ldots \ldots \ldots \ldots \ldots \ldots \ldots \ldots \ldots \ldots \ldots . \ldots .4 . \ldots \ldots$

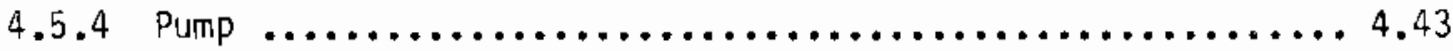

4.5 .5 Slurry Instrumentation $\ldots \ldots \ldots \ldots \ldots \ldots \ldots \ldots \ldots \ldots \ldots \ldots . . \ldots \ldots$ 
4.5 .6 Trench $\ldots \ldots \ldots \ldots \ldots \ldots \ldots \ldots \ldots \ldots \ldots \ldots \ldots \ldots \ldots \ldots \ldots .4 . \ldots \ldots$

5.0 CONCLUSIONS AND RECOMHENDATIONS $\ldots \ldots \ldots \ldots \ldots \ldots \ldots \ldots \ldots \ldots \ldots \ldots \ldots \ldots \ldots$

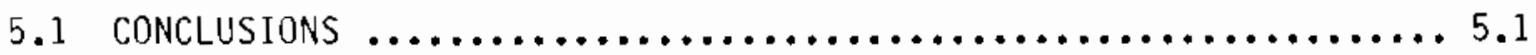

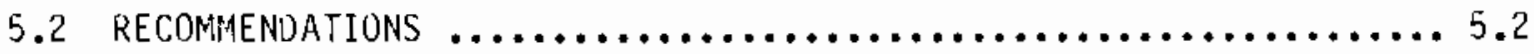

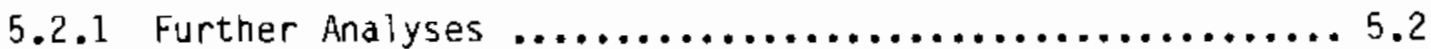

5.2 .2 Transportable Grout Facility .................... 5.2

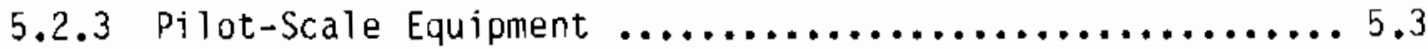

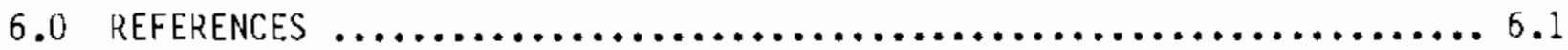





\section{FIGURES}

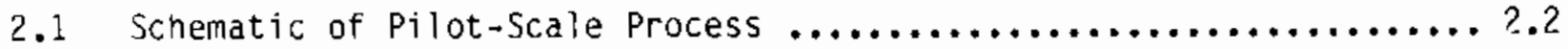

2.2 Dry Blend Supply Trailer $\ldots \ldots \ldots \ldots \ldots \ldots \ldots \ldots \ldots \ldots \ldots \ldots \ldots \ldots \ldots . \ldots \ldots$

2.3 The Dry Blend Transfer/Feed System $\ldots \ldots \ldots \ldots \ldots \ldots \ldots \ldots \ldots \ldots \ldots \ldots . . \ldots$

2.4 The Continuous Grout Mixer $\ldots \ldots \ldots \ldots \ldots \ldots \ldots \ldots \ldots \ldots \ldots \ldots \ldots \ldots \ldots \ldots$

2.5 Internal View of Grout Mixer $\ldots \ldots \ldots \ldots \ldots \ldots \ldots \ldots \ldots \ldots \ldots \ldots \ldots \ldots . \ldots \ldots$

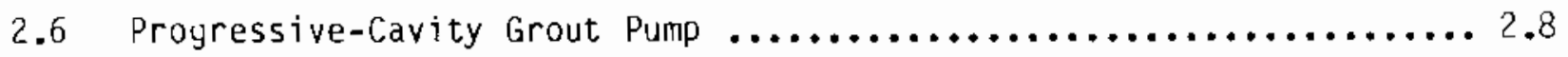

2.7 Schematic of Grout Trench $\ldots \ldots \ldots \ldots \ldots \ldots \ldots \ldots \ldots \ldots \ldots \ldots \ldots \ldots . \ldots \ldots$

2.8 Cross-Section of HDPE Seams Used in the Trench Liner ............ 2.9

2.9 Trench Under Construction $\ldots \ldots \ldots \ldots \ldots \ldots \ldots \ldots \ldots \ldots \ldots \ldots \ldots \ldots \ldots \ldots . \ldots 11$

2.10 Completed Trench Cover $\ldots \ldots \ldots \ldots \ldots \ldots \ldots \ldots \ldots \ldots \ldots \ldots \ldots \ldots \ldots \ldots \ldots \ldots . \ldots . \ldots . \ldots$

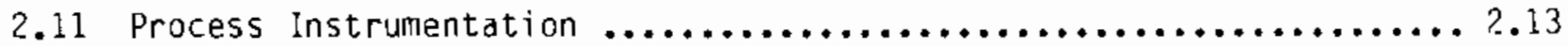

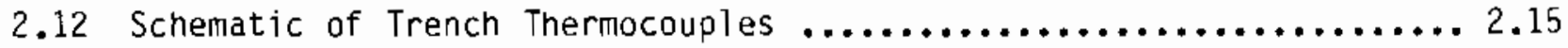

3.1 Grout Sampler Designed for Pilot-Scale Test .....................

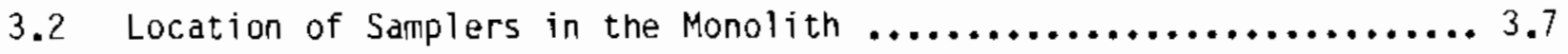

4.1 Specific Gravity of Grout at Surge Tank and at Discharge to Trench ........................................ 4.2

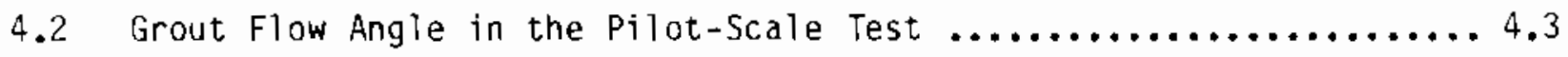

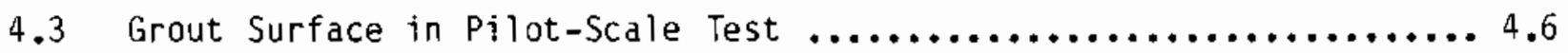

4.4 Grout Surface in Previous Test with Higher Mix Ratio ............4.7

4.5 Volume of Separated Liquid $\ldots \ldots \ldots \ldots \ldots \ldots \ldots \ldots \ldots \ldots \ldots \ldots \ldots \ldots \ldots . \ldots . \ldots . \ldots \ldots$

4.6 Temperature Profile - 2 ft From Discharge Nozzle .............. 4..14

4.7 Temperature Profile - $17 \mathrm{ft}$ from Discharge Nozzle .............4.15

4.8 Temperature Profile - $40 \mathrm{ft}$ From Discharge Nozzle .............. 4.15

4.9 Temperature $3 \mathrm{ft}$ From Trench Floor at Three Trench Locations ...... 4.16

4.10 Isotherms in Pilot-Scale Trench Two Days After Production ........4.17 
4.11 Theoretical Adiabatic Temperature Rise in Simulated

PSW Grout as a Function of Mix Ratio $\ldots \ldots \ldots \ldots \ldots \ldots \ldots \ldots \ldots, \ldots .17$

4.12 Pilot-Scale Test Critical Flow Rates at the Surge Tank

and at the Discharge to the Trench $\ldots \ldots \ldots \ldots \ldots \ldots \ldots \ldots \ldots \ldots \ldots . .24$

4.13 Grout Buildup at the Dry Blend Inlet Port

Prior to Installation of Flushing System $\ldots \ldots \ldots \ldots \ldots \ldots \ldots \ldots . . .29$

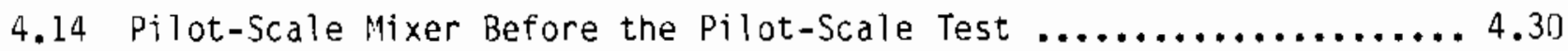

4.15 Pilot-Scale Mixer After the Pilot-Scale Test ................... 4.31

4.16 Dry Blend Inlet Port in Mixer Cover After the Pilot-Scale Test ..... 4.32

4.17 Cured Grout in Pump Inlet Without Flush System ................. 4.34

4.18 Grout Buildup in a Section of Ptlot-Scale Piping $\ldots \ldots \ldots \ldots \ldots \ldots . . .4 .36$

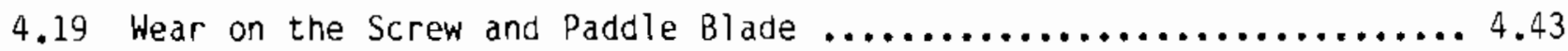

4.20 Pump Calibrations Before and After the Pilot-Scale Test .......... 4.44 


\section{TABLES}

3.1 Formulas for Preparation of Phosphate and Sulfate Wastes ......... 3.2

3.2 Target and Measured Concentrations of Simulated PSW .................

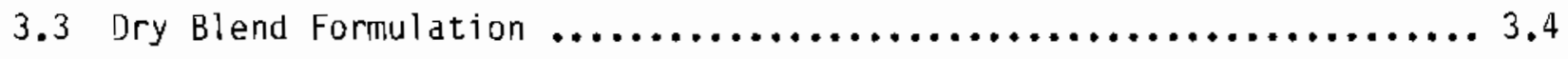

4.1 Comparison of the Compositions of PSW and Separated Liquid ........4.11

4.2 Comparison of the Calculated Pressure Drops and

observed Pressure Drops .............................4.26 


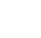




\subsection{INTRODUCTION}

Plans are underway at the Hanford Site near Richland, Washington, to convert the low-level fraction of radioactive liquid wastes to a grout form for permanent disposal. Grout is a mixture of liquid waste and grout formers, including portland cement, fly ash, and clays. In the plan, the mixture is pumped to subsurface concrete vaults on the Hanford Site, where the grout will harden into large monoliths, thereby immobilizing the waste. A simitar disposat concept is being planned at the Savannah River Laboratory site. The underground disposal of grout was conducted at Oak Ridge National Laboratory between 1966 and 1984 .

Design and construction of grout processing and disposal facilities are underway. The Transportable Grout Facility (TGF), operated by Rockwell Hanford Operations (Rockwe11) for the Department of Energy (DOE), is scheduled to grout Phosphate/Sulfate $\mathrm{N}$ Reactor Operations Waste (PSW) in FY 1988. Phosphate/ Sulfate Waste is a blend of two low-level waste streams generated at Hanford's $N$ Reactor. (The $N$ Reactor produces special nuclear materials, and its byproduct steam is used to generate electricity). Other wastes are scheduled to be grouted in subsequent years.

The Transportable Grout Facility includes the Dry Materials Receiving and Handling Facility (DMRHF) and the Transportable Grout Equipment (TGE). Cement, clays, and fly ash will be received, stored, and blended at the DMRHF. The blended material will be loaded and shipped to the TGE. In the TGE, the dry material will be mixed with the liquid waste to form grout. The TGE consists of seven transportable modules: 1) dry blend module, 2) mixer, pump and liquid collection module, 3) control room module, 4) electrical equipment module, 5) heating, ventilating and cooling module, 6) standby generator module, and 7) additives and decontamination module.

The grout produced in the TGE will be pumped to subsurface disposal vaults. The vaults are concrete enclosures with a 1.4 mitiion gallon capacity. Vau1t dimensions are 125 feet 1 ong by 50 feet wide by 35 feet deep. Vaults will contain a liner system consisting of a drainage net between two layers of 60-mil-thick, high-density polyethylene. 
Pacific Northwest Laboratory (PNL) is verifying that Hanford grouts can be safely and efficiently processed. To meet this objective, pilot-scale grout process equipment was installed. The pilot-scale process equipment can produce grout at a rate of up to $25 \%$ of the maximum rate of $70 \mathrm{gpm}$ planned for the TGF. Since 1984, PNL has performed seven major tests with pilot-scale equipment, producing simulated PSW grout to evaluate the performance of process equipment and grout behavior.

This report presents the results of a 24-hr test of the pilot-scale grout. process conducted on July 29 and 30, 1986. Results of earlier, unreported pilot-scale tests are also cited for comparison.

\subsection{OBJECTIVES OF THE PILOT-SCALE TEST}

The three objectives of the pilot-scale test were: 1) to determine the homogeneity of the grout produced under conditions similar to those planned for the TGF, 2) to evaluate performance of candidate grout processing equipment for the TGF, and 3) to evaluate properties of grout that was produced during continuous operation over an extended time period and disposed in a large trench.

Because of the extended duration of the test, process data were obtained that will be useful in the design of the full-scale grout process equipment and in the development of the operating procedures for the TGF. Additionally, observations of grout behavior and measurements of grout properties in a disposal system similar to the proposed vaults will support the design of the disposal vaults.

\subsection{SCOPE OF PILOT-SCALE TEST}

A large grout monolith (approximately 22,000 gallons) was produced using simulated nonradioactive PSW and a cementitious blend of dry materials based on

a formulation developed by Oak Ridge National Laboratory. (a) The test utilized

(a) Letter Report McDaniel, E. W. et al. Grout Formulation Studies with Hanford Facility Waste: An Executive Summary. Oak Ridge National Laboratory, Oak Ridge, Tennessee (September 1984). 
pilot-scale grout processing equipment similar to those proposed for the TGE. Grout was produced at a rate of $15 \mathrm{gpm}$.

The simulated PSW contained nonradioactive trace components simulating corrosion products. The dry blend of grout formers used in the test was produced at the Dry Materials Receiving and Handling Facility (DMRHF). The DMRHF is an integral part of the TGF.

During grout production, data were taken to evaluate equipment performance, homogeneity of the grout produced under conditions similar to those planned for the Transportable Grout Facility Equipment (TGE), equipment flush requirements, and grout physical and rheological properties. Grout physical and rheological properties were evaluated at both the mixer discharge and the trench discharge to examine the effect of shear in the pipe on these properties.

The grout was disposed in a 30,000-gal capacity trench that had features similar to the vaults to be used for disposal of actual PSW grout. The trench was lined with 60-mil-thick high-density polyethylene (HDPE). A plastic cover was placed over the trench to prevent entry of foreign material and evaporation of water from the grout. Access ports in the cover allowed operators to insert sample tubes, observe grout behavior in the trench, and withdraw samples.

During the first month after the grout was produced, samples of separated liquid on the grout surface were collected three times per week and analyzed for $\mathrm{pH}$, heavy metals, and organic carbon. Grout temperatures were monitored at least every day. The volume of separated liquid was monitored until it was completely reabsorbed 30 days after the grout was produced. Grout core samples were extracted from the monolith on the 28 th day and stored in vapor-tight containers for subsequent physical and chemical tests.

In the fall of 1986 , the grout monolith was insulated and covered with an additional layer of plastic. Temperature measurements in the monolith will continue as long as the effort is justified. After approximately 8 months, the monolith will be examined to determine the frequency of crack development in the grout. The monolith will then be dug up and permanentiy disposed in a landfill. 
A sampling plan for the pilot-scale test was prepared to provide a statistical basis for determination of the homogeneity of the grout and other grout properties. The plan called for tests on the simulated waste, the dry blend, the fresh and cured grout, and the separated liquid. These analyses will be used to assess the uniformity of the grout in the monolith and to provide data on the physical properties needed to assess the long-term performance of disposed grout.

This report discusses the operational aspects of the pilot-scale test in detail. Whenever possible, discussions are included that relate the performance observed during the pilot-scale test to the performance expected in the TGF.

The pilot-scale equipment and trench are described in Chapter 2.0. The procedures for preparation of the dry blend, preparation of simulated PSW, and sampling are discussed in Chapter 3.0. Chapter 4.0 reports results of the pilot-scale test. This chapter includes evaluations of three areas: 1) equip.ment performance, 2) flush system performance and requirements, and 3) behavior of grout in the trench. Chapter 4.0 also presents the results of laboratory rheology tests performed prior to and during the test. Chapter 5.0 summarizes conclusions from the pilot-scale test, as well as recommendations for the TGF design and for improvements in the pilot-scale system. 


\subsection{DESCRIPTION OF EQUIPMENT AND TRENCH}

This chapter describes the pilot-scale grout processing equipment and disposal trench. The equipment is sized to process grout at up to $25 \%$ of the $70 \mathrm{gpm}$ maximum production rate planned for the TGF. A schematic of the system is shown in Figure 2.1, each component is discussed.

\subsection{WASTE SUPPLY}

Simulated waste was pumped to the grout processing equipment from a 23,000-gal carbon steel tank. (Section 3.1 describes the simulated waste preparation and composition.) Two parallel centrifugal pumps (one for backup) supplied the waste to the grout mixer. Part of the waste stream was recirculated back to the tank. The recirculation loop was designed to prevent complete stoppage of flow in the event the waste flow to the mixer was stopped. A second recirculation system served to suspend precipitated material in the waste. This system consisted of a 1-horsepower pump and a flow distribution header with 170 nozzles. The distribution header was located on the floor of the tank.

The waste flow rate was controlled with a manually operated gate valve. Flow rate instrumentation is described in Section 2.7.2. The temperature of the waste was measured near the inlet to the grout mixer and recorded on a datalogger.

The synthetic waste was prepared in batches in an agitated 4,200-gal stainless-steel tank and then pumped to the feed tank. Section 3.1 discusses the procedures used to prepare the waste.

Tributyl phosphate (TBP), a deaerating agent, was added to the waste at the mixer inlet. A teflon diaphragm pump was used to meter the TBP at a rate equal to $0.02 \%$ of the waste volumetric rate.

\subsection{DRY BLEND FEED}

Components of the dry-blend feed system include the supply trailer, the trailer-to-storage bin transfer system, the storage bin/baghouse, the active bin/feeder, and the scalping screen. 


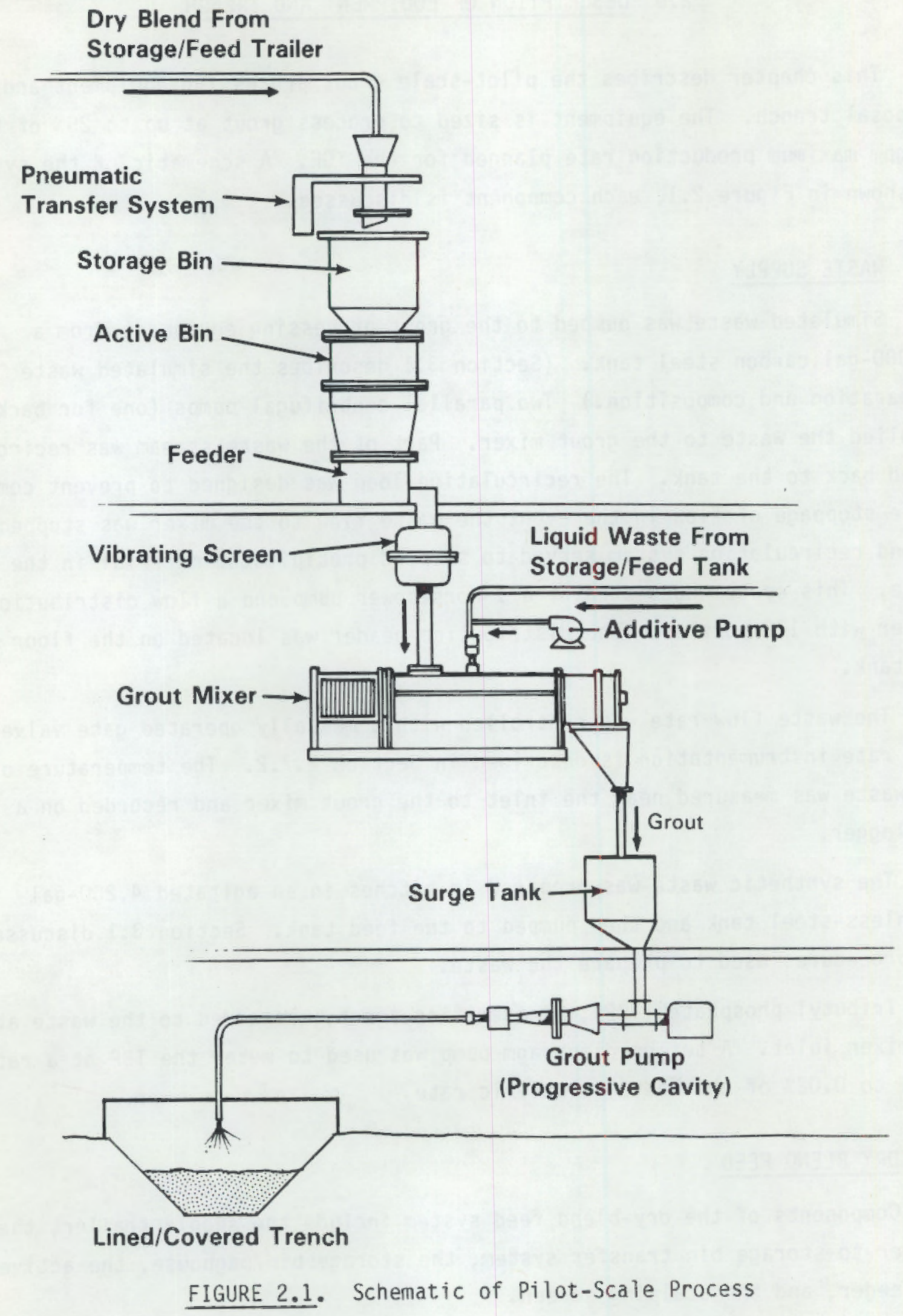


Dry blend (a mixture of 41 wt\% portland cement I \& II, 40 wt\% Class F fly ash, 11 wt\% Attapulgite-150 drilling clay, and 8 wt\% Indian Red Pottery Clay) was supplied in trailers, each with a 1000-ft ${ }^{3}$ capacity (Figure 2.2). The dry blend was produced at the DMRHF. Three trailer loads were used during the test.

Ising a vacuum system, dry blend was transferred in batches from the trailer unloading port to a storage bin with a $27-\mathrm{ft}^{3}$ capacity. The storage bin contains a baghouse to separate the dry blend from the transfer air. (The transfer system and storage bin were manufactured by Vac-U-Max ${ }^{\circledR}$ )

The storage bin is located above the active bin/feeder. The contents of the storage bin were automatically dumped to the active bin on a signal from

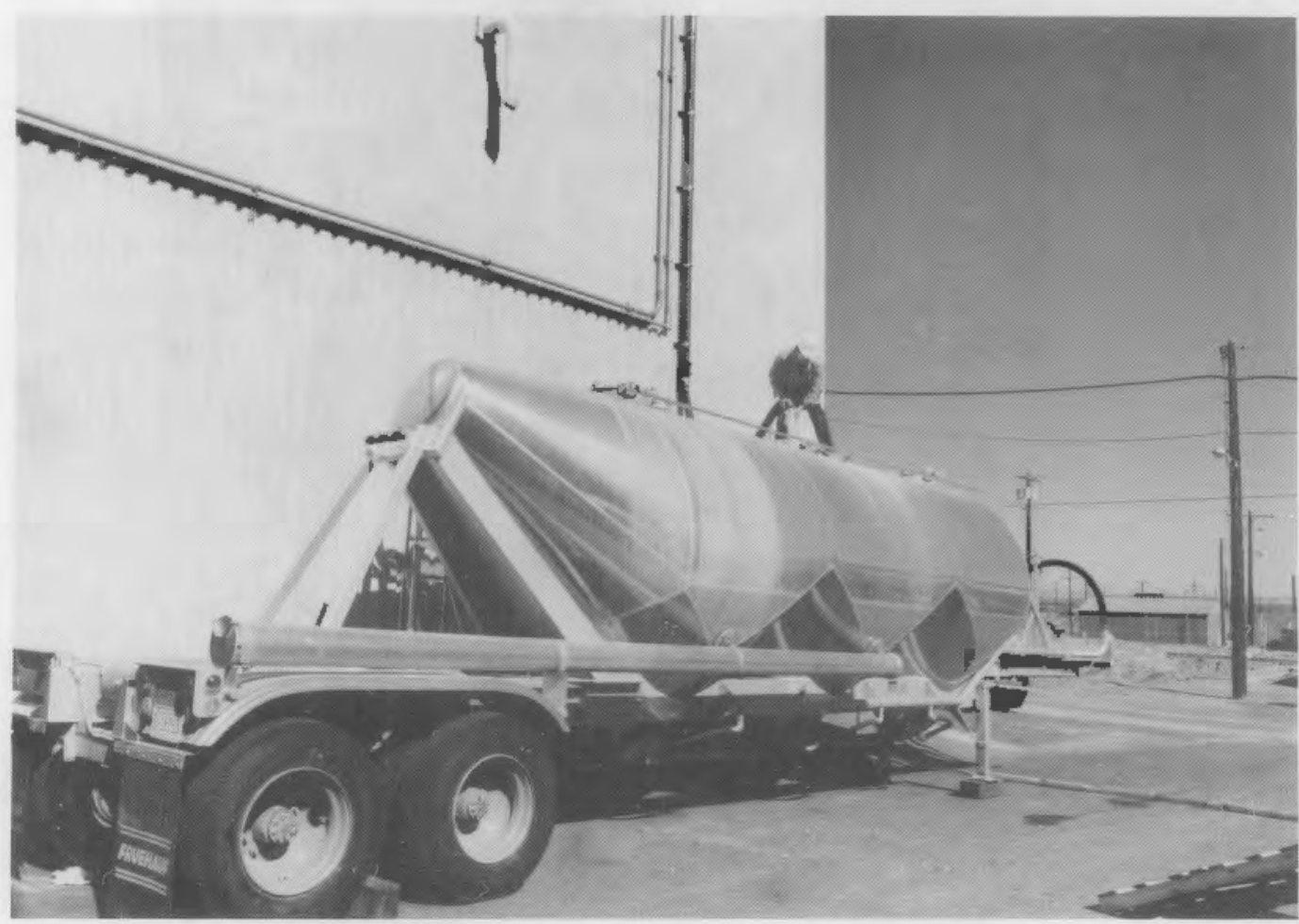

FIGURE 2.2. Dry Blend Supply Trailer

(a) Tradename of Vac-U-Max, Belleville, New Jersey. 
the feeder controller. Figure 2.3 shows the baghouse/storage bin, active bin/ feeder, and vacuum transfer pump. The active bin has a capacity of $36.6 \mathrm{ft}^{3}$ and an active volume of $30 \mathrm{ft}^{3}$. The feeder is an Acrison gravimetric (augertype) feeder with a weight rate accuracy of $0.5 \%$ of the set point. When the feed bin weight reaches a predetermined low level, the feeder is automatically

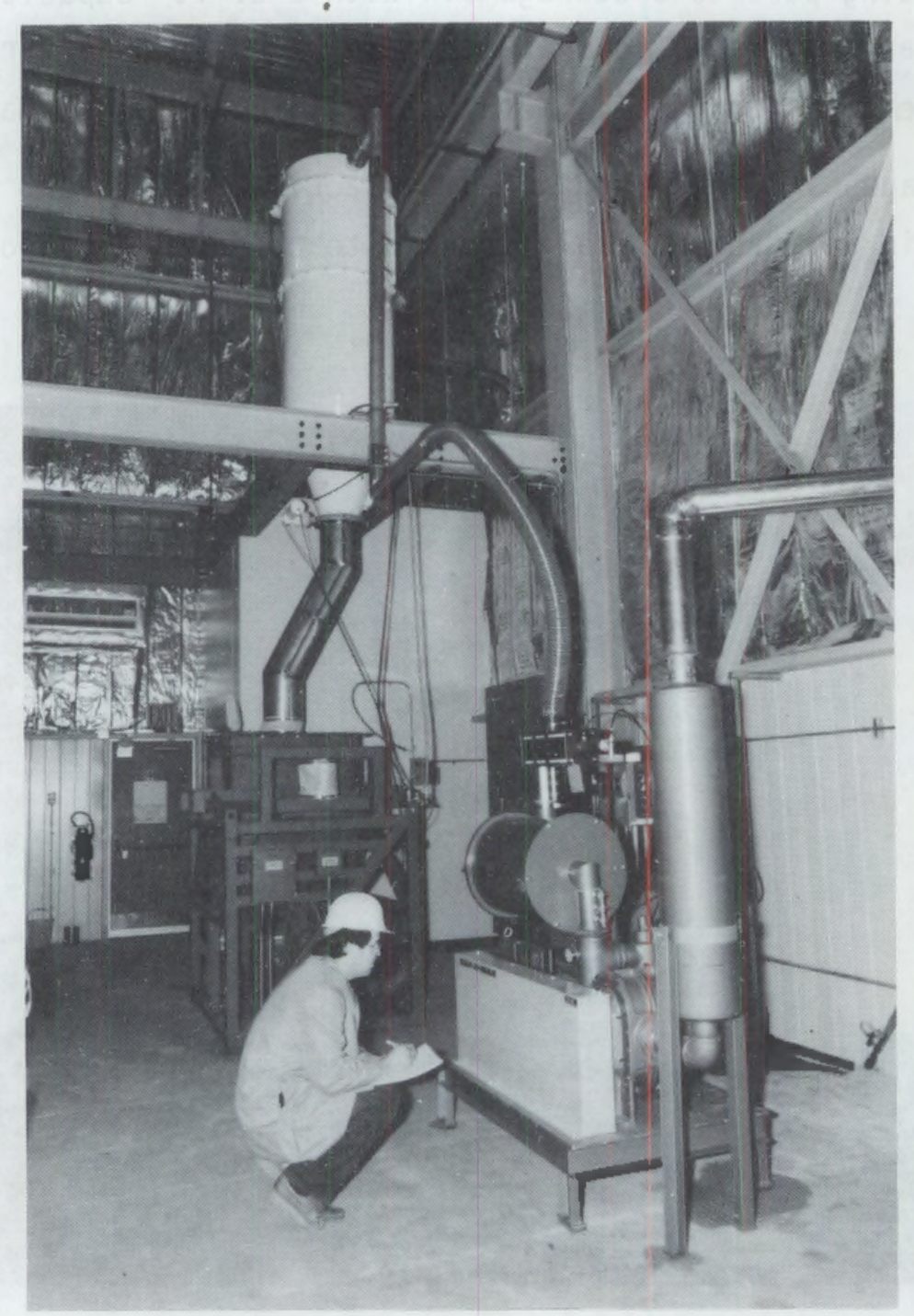

FIGURE 2.3. The Dry Blend Transfer/Feed System. Storage bin/baghouse is above the feeder; the transfer blower is in the foreground.

(3) Tradename of Acrison, Inc., Moonachie, New Jersey. 
switched to a volumetric mode and a valve between the feeder and the storage bin is opened for reloading. At this time, a vibrator and air pads on the storage bin are activated to promote the discharge of dry blend from the storage bin. The reload valve is closed when the weight reaches $90 \%$ of the feeder capacity.

Excellent feeder performance was demonstrated in pre-tests in support of the pilot-scale test. The pilot-scale feed system differs significantly from the gravimetric belt feed system planned for the TGF.

The feeder discharged into a Sweco vibrating screen. This $18-i n$. diameter scalping screen was designed to remove material greater than 0.20 inch from the dry feed. The oversize material is collected in a 5-gallon receiving drum. The TGE will also use a vibrating screen upstream of the continuous grout mixer.

\subsection{MIXER}

Dry blend and simulated waste are combined in the mixer to produce a grout slurry. The grout mixer is a Teledyne Readco 5.25-in. Continuous Processor (Figure 2.4). Dry blend and simulated waste enter at the top of the mixer. The grout discharges at the opposite end of the mixer to the pump surge tank. The mixer has a water spray system for flushing the dry-blend inlet and grout discharge sections. Figure 2.5 shows the interior of the mixer. Dry blend is introduced at the left end into the screw section. Liquid is introduced where the mixer paddles begin. The paddles are 1 inch wide and provide low-shear mixing of grout during mixer operation.

Mixing speed is adjustable from 50 to $270 \mathrm{rpm}$. For the pilot-scale test, the mixer was operated at $250 \mathrm{rpm}$, a speed that had been chosen based on results of tests that showed that slightly less dusting occurred at higher rpm's without measurable effects on the grout properties. The mixer has an adjustable discharge gate that can be used to adjust residence time of grout in the mixer. Partial closure of the discharge gate was also found to reduce dusting, probably due to the increase in residence time of the grout.

(3) Tradename of Sweco, Inc., Los Angeles, California.

(3) Tradename of Teledyne Readco, York, Pennsylvania. 


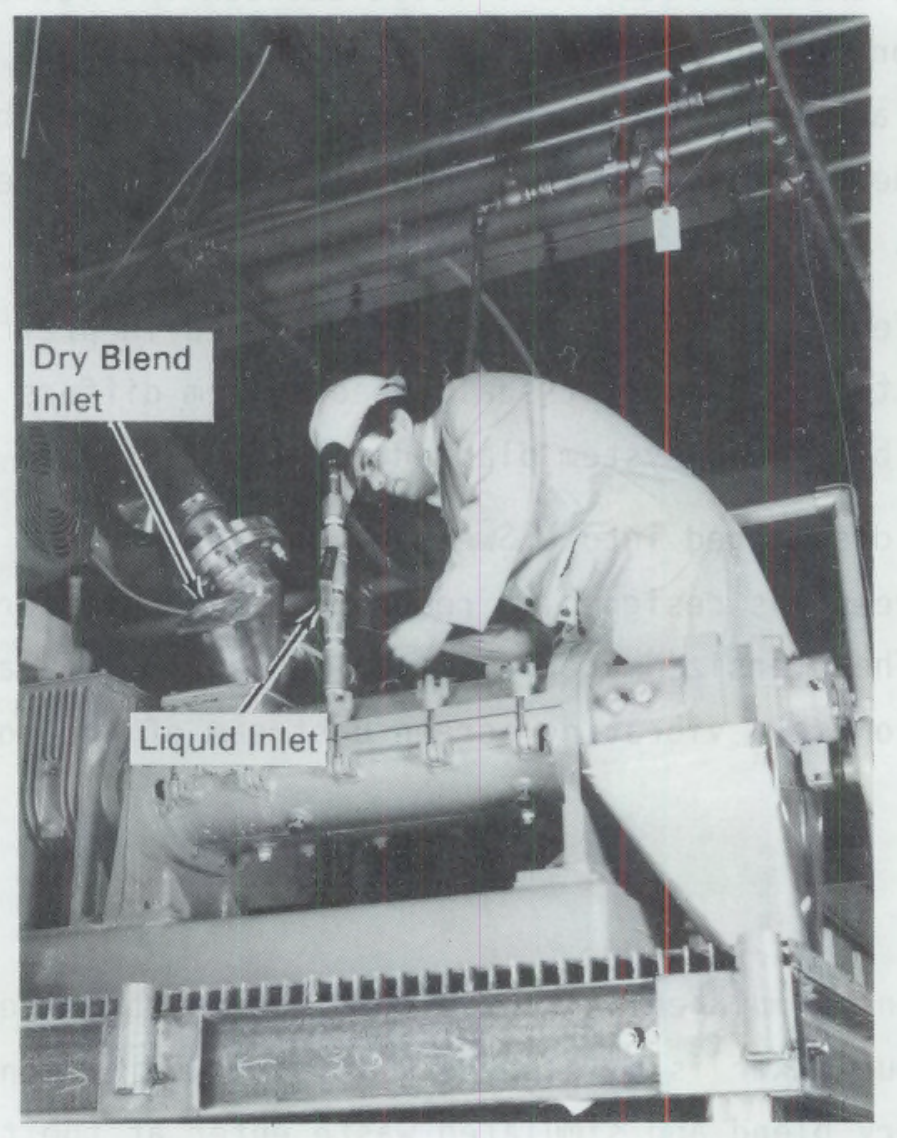

\section{FIGURE 2.4. The Continuous Grout Mixer}

The mixer that will be used for the TGE mixer will also be manufactured by Teledyne-Readco. The mixing paddle will be 7 inches long instead of 5.25 inches, and the mixer will have no adjustable discharge gate. The performance of the TGE mixer is expected to be very similar to that of the pilotscale mixer.

The pilot-scale mixer discharges grout into a surge tank where operators can sample grout and measure the grout production rate. The surge tank is 19 inches in diameter and 20 inches deep, with a cone-shaped base. Screens in the surge tank are used to collect foreign material to prevent damage of the grout pump. The first screen is cylindrical ( 6 inches in diameter) with 0.1 in. openings. This screen catches any oversize material from the mixer. The second screen (with $\sim 0.5-i n$. openings) is at the base of the surge tank and 


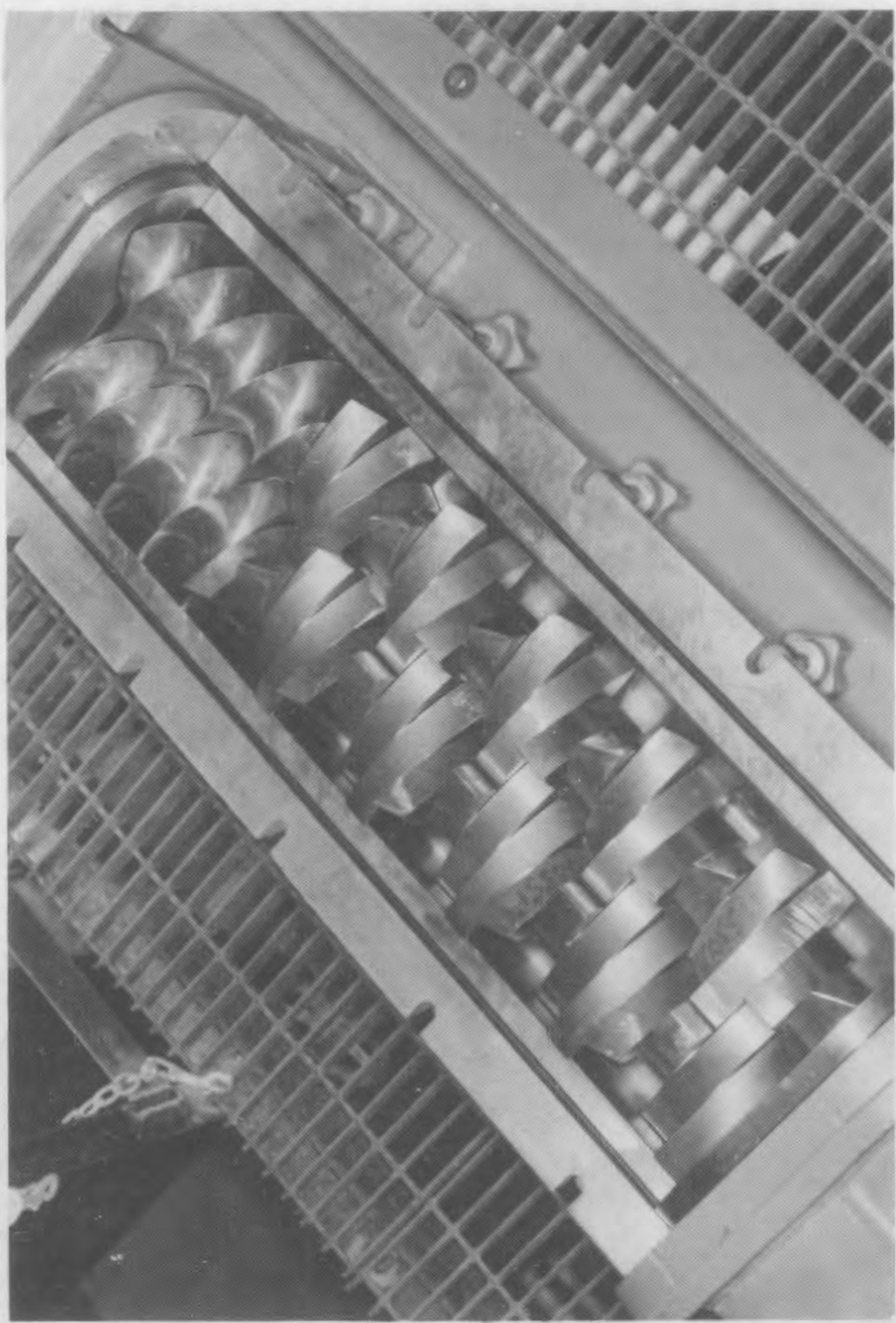

FIGURE 2.5. Internal View of Grout Mixer

provides protection in case items are accidentally dropped into the surge tank. These screens will not be used in the TGE because the surge tank will be a closed vessel. Also, the TGE pump is capable of passing much larger particles without damaging the pump. Because the pilot-scale surge tank is open, however, there is greater potential for foreign material to reach the pump. 


\subsection{GROUT PUMP}

The grout pump is a two-stage progressive-cavity pump (Figure 2.6) with an ethylene-propylene-diene-monomer (EPDM) stator. The pump seal is a waterlubricated packing gland. The pump speed is manually controlled with a digital-setpoint speed control and a digital rpm indicator to maintain a constant level of grout in the surge tank. The pump amperage and speed are recorded on the datalogger. A progressive-cavity grout pump will also be used as the TGE pump; however, it will have more stages to produce the higher pressure required to pump grout over longer distances to vaults.

\subsection{PIPING}

The grout pump discharges grout into a $1-i n$. Schedule 40 , carbon steel pipe that runs to the trench. The piping was sized to maintain turbulent flow at the planned production rate of $15 \mathrm{gpm}$ assuming typical rheological

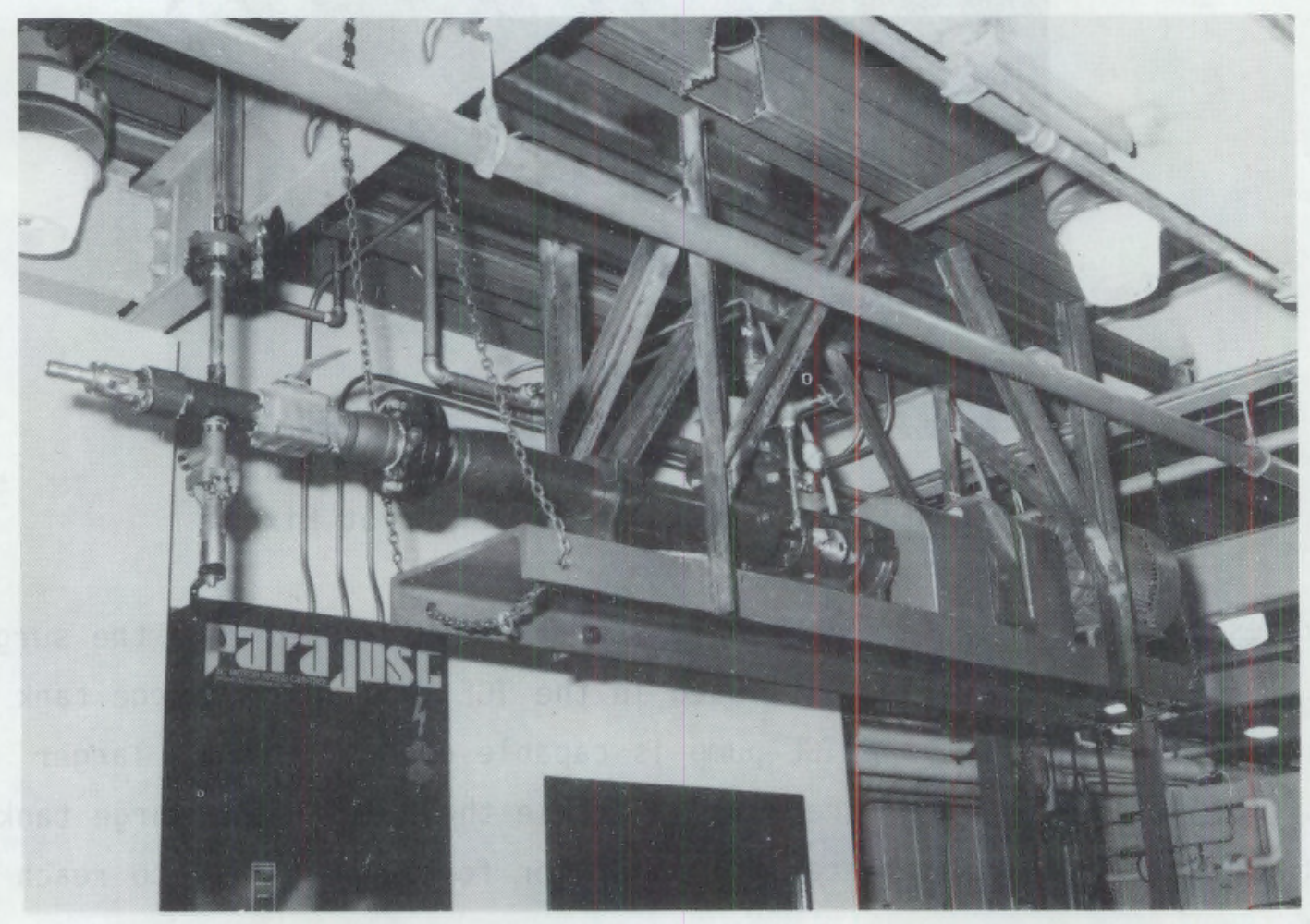

FIGURE 2.6 Progressive-Cavity Grout Pump 
properties of PSW grout. In the pilot-scale test, the piping had an equivalent length of 155 feet and contained eight long-radius (4-in.) elbows. The long radius elbows were used to minimize both erosion rates and the likelihood of developing "dead spots" where grout solids could collect. Grout was discharged vertically to the trench at a single point through the trench roof.

\subsection{TRENCH}

The pilot-scale trench was 8 feet deep with $45^{\circ}$ side slopes. The dimensions at the top of the trench were 60 feet by 20 feet (Figure 2.7). The capacity, excluding 1 foot of freeboard, was 30,000 gallons. The trench was lined with a sheet of 60-mil-thick HDPE. The trench design for the pilot-scale test was based on the then-current design for disposing of the radioactive grouted waste. Since that time, the disposal concept evolved from trenches to disposal vaults. The current vault design includes vertical side walls, top dimensions of 125 feet by 50 feet, and a liner system consisting of a drainage net sandwiched between two layers of 60-mil-thick HDPE.

The HDPE for the pilot-scale trench was procured from and installed by Northwest Linings; (a) the HDPE liner was manufactured by National Sea1.(b) The liner was seamed, where practical, using a double-wedge, heat-welded seam method. An extrusion weld process was used where the heat welder could not be used. Figures $2.8 \mathrm{a}$ and $\mathrm{b}$ show schematics of the types of seams made by these two processes. Figure 2.9 shows the trench during liner installation.

Double-weld seams were tested for leaks by sealing each end of a seam and then inserting a needle in the air space between the two welds. The seams were pressurized to about 30 psi with air, and the bleed rate was observed. The criterion for unacceptable seams was a bleed rate greater than 4 psi over 15 minutes; however, all seams tested by this method were acceptable. Some of the extruded seams and patches were tested by a vacuum box inspection method; however, due to the uneven subgrade, this technique was not very effective and therefore was not used extensively. Instead, visual examinations and "pick"

(a) Northwest Linings, Bellevue, Washington.

(b) National Seal, Palantine, Illinois. 

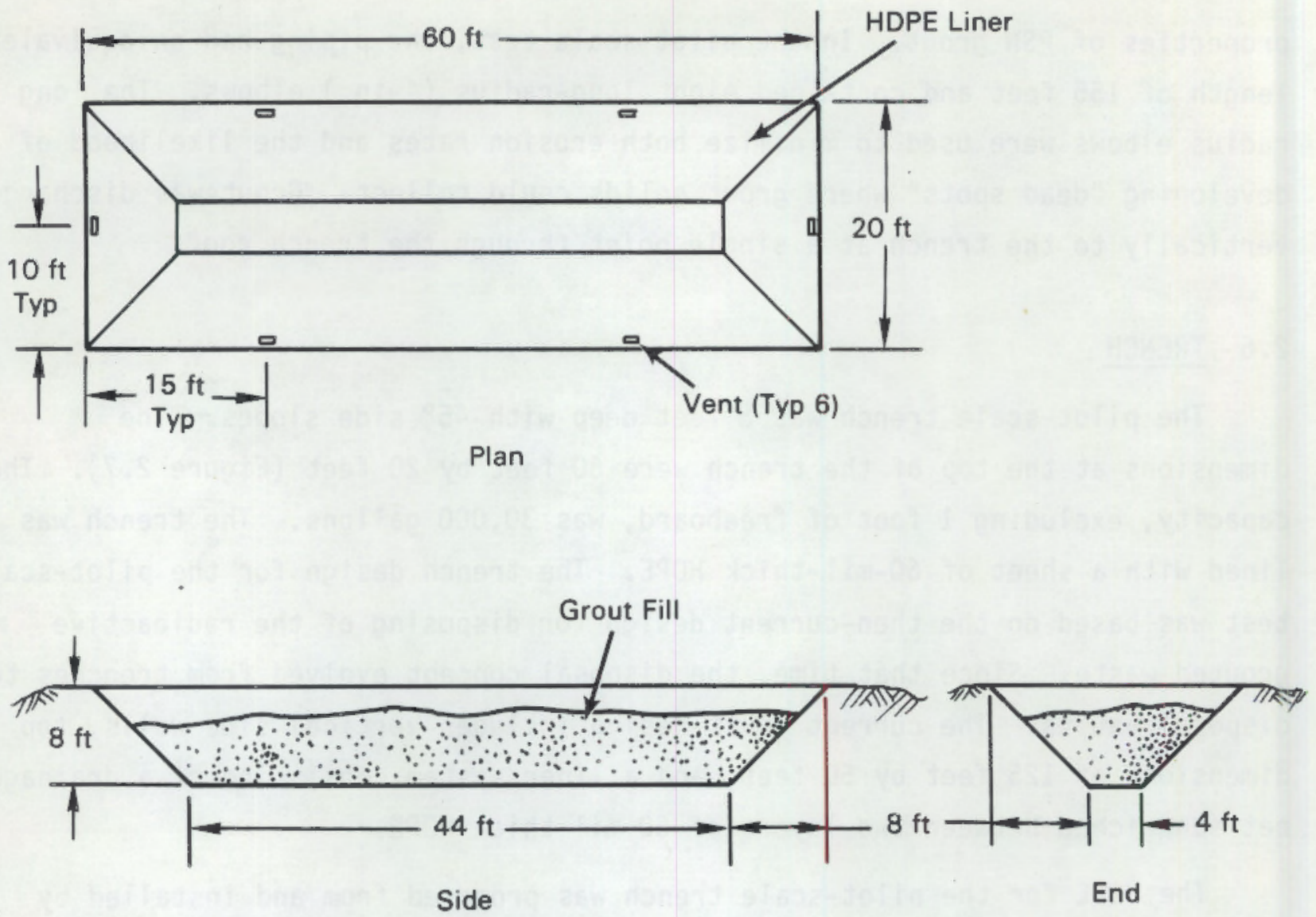

FIGURE 2.7. Schematic of Grout Trench

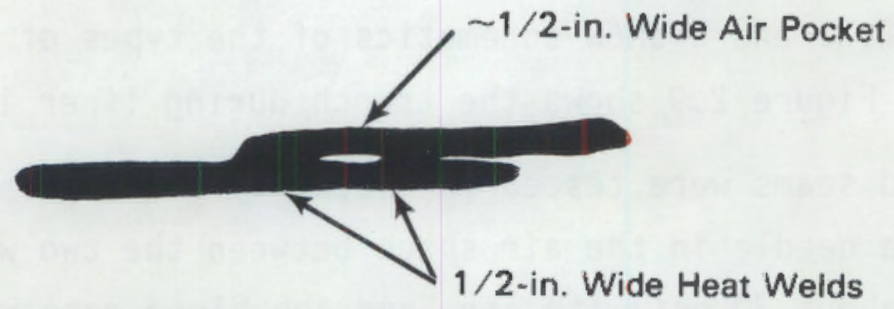

a) Double Wedge Heat-Welded Seam

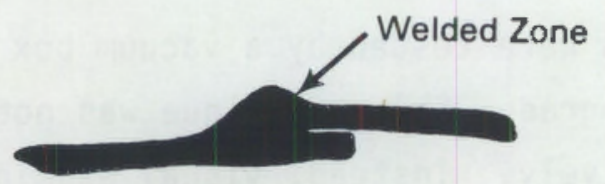

b) Extrusion Fillet Weld Seam

FIGURE 2.8. Cross-Section of HDPE Seams Used in the Trench Liner 


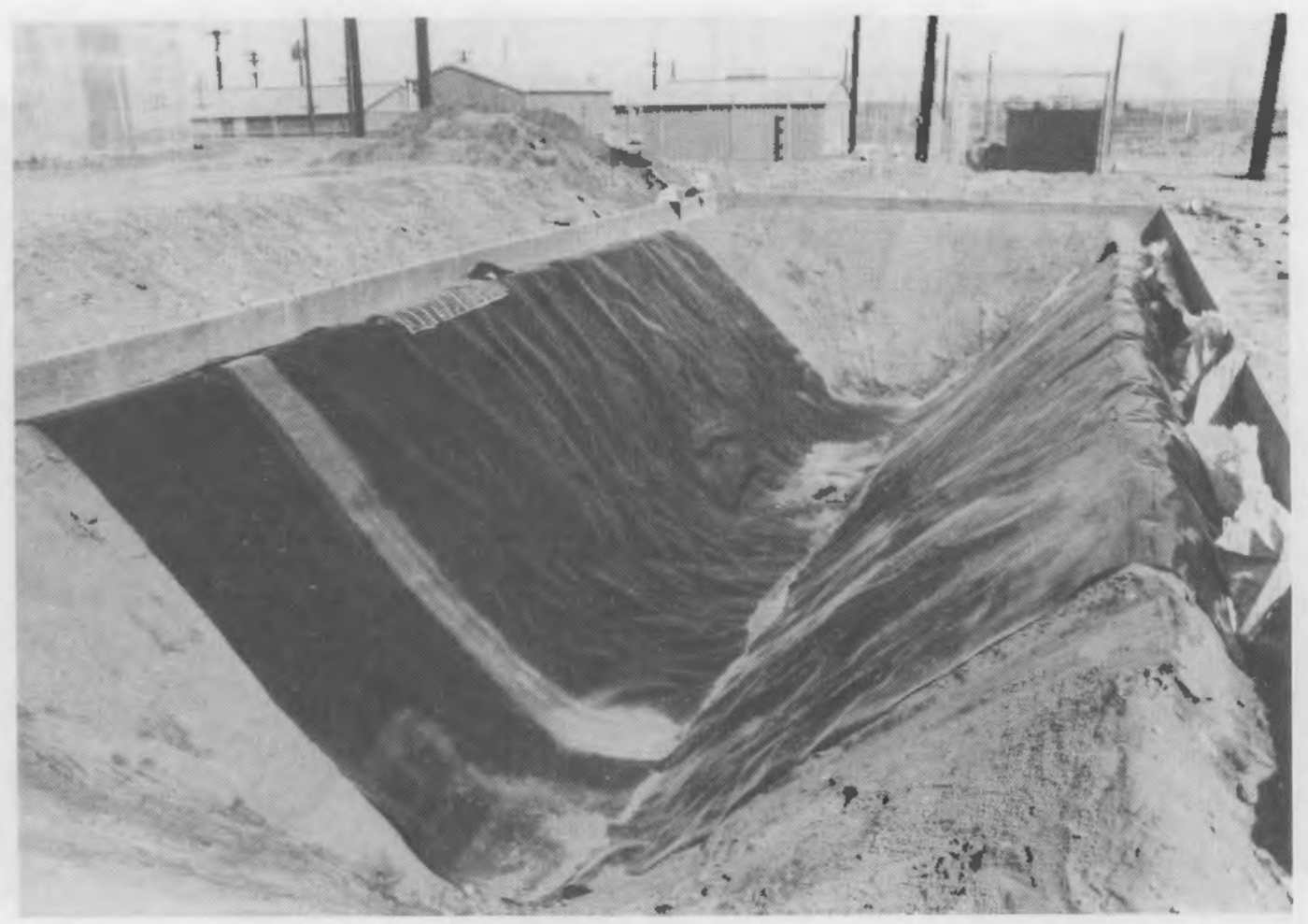

FIGURE 2.9. Trench Under Construction

tests were performed. (In a pick test, a pointed object, e.g., a nail, its run along the edge of the seam to determine whether the bond is continuous between the two layers.)

A wood-frame roof was constructed over the trench. A 20-mil-thick polyvinyl chloride (PVC) vapor barrier was placed over the wood frame. Several access ports were built on the top and sides of the cover to permit sampling of grout, observation of grout flow angle, and estimation of separated liquid volume. Marks on the trench liner were used to measure grout flow angles and to estimate separated liquid volume. Figure 2.9 shows the trench under construction and Figure 2.10 shows the completed trench cover with samplers (vertical pipes) installed after the test.

The grout discharge nozzle was located near one end of the trench so that grout flowed approximately 50 feet under conditions similar to those expected 


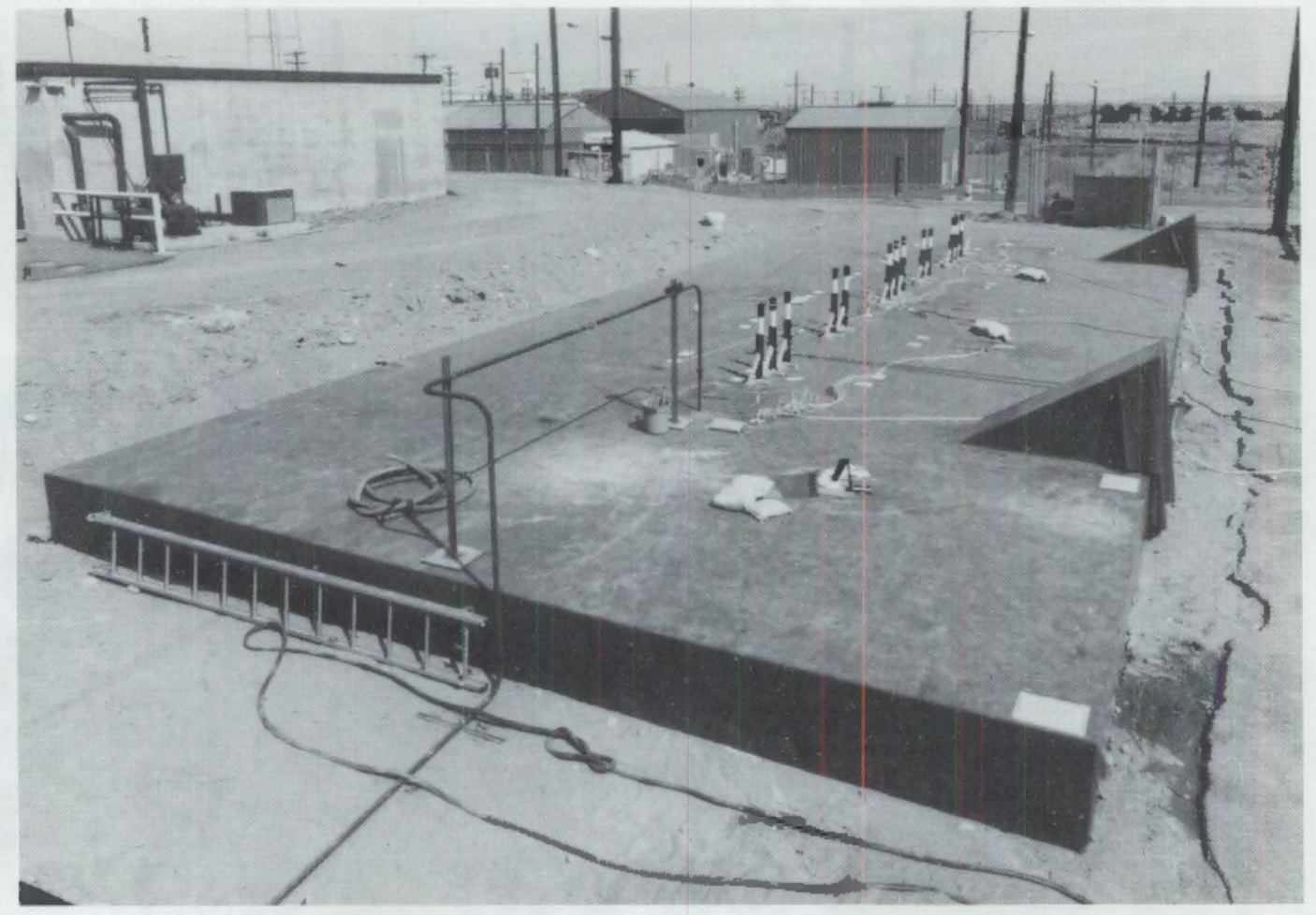

FIGURE 2.10. Completed Trench Cover

in vaults for PSW grout. (Grout would flow a maximum distance of 67 feet in the current design for a disposal vault.)

During the week prior to grout production, the trench liner was washed to remove dust and debris that had collected during construction of the cover. The soil in the anchor trenches for the liner was soaked with water to minimize its capacity to absorb moisture from the trench vapor space.

\subsection{PROCESS INSTRUMENTATION}

Process instrumentation is depicted in Figure 2.11. The datalogger recorded outputs from most instruments in 15-min. intervals. The various instruments used in the test are described below. 


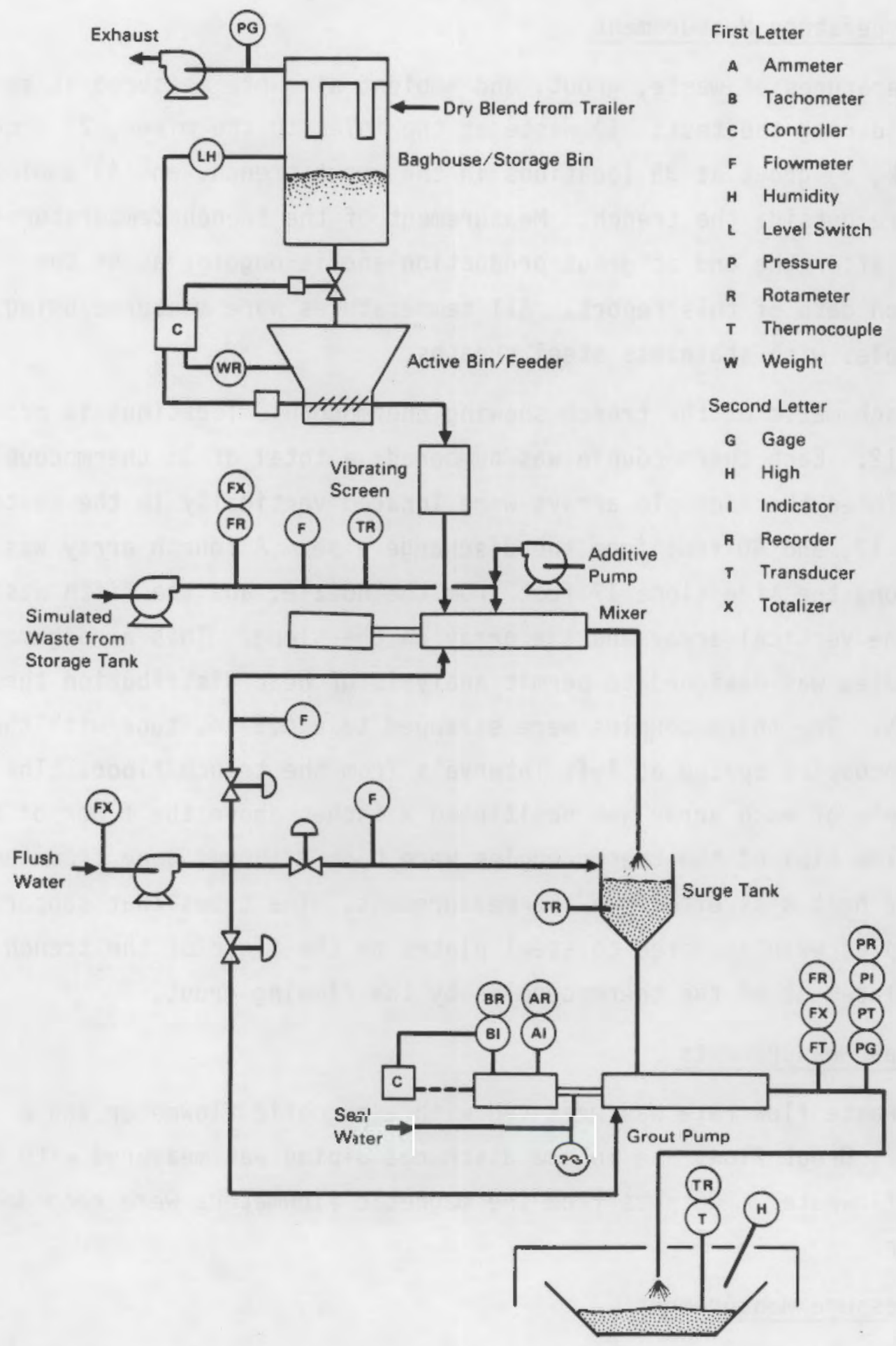

FIGURE 2.11. Process Instrumentation 


\subsubsection{Temperature Measurement}

Temperatures of waste, grout, and ambient air were measured at several locations during the test: 1) waste at the inlet to the mixer, 2) grout in the surge tank, 3) grout at 35 locations in the grout trench, and 4) ambient air temperature outside the trench. Measurement of the trench temperatures continued after the end of grout production and is ongoing as of the publication date of this report. All temperatures were measured using Type $K$ thermocouples with stainless steel sheaths.

The schematic of the trench showing thermocouple locations is provided in Figure 2.12. Each thermocouple was numbered; a total of 35 thermocouples were placed. Three thermocouple arrays were located vertically in the center of the trench 2, 17, and 40 feet from the discharge pipe. A fourth array was positioned along the side slope 17 feet from the nozzle, and the fifth was located between the vertical array and the array on the slope. This arrangement of the thermocouples was designed to permit analysis of heat distribution throughout the trench. The thermocouples were strapped to a 0.5-in. tube with the ends of the thermocouples spaced at 1-ft intervals from the trench floor. The lowest thermocouple of each array was positioned 2 inches above the floor of the trench. The tips of the thermocouples were bent 2 inches away from the tube to reduce the heat sink effect on the measurement. The tubes that supported the thermocouples were anchored to steel plates on the floor of the trench to prevent displacement of the thermocouples by the flowing grout.

\subsubsection{Flow Measurements}

The waste flow rate was measured with a magnetic flowmeter and a rotameter. Grout flow rate in the discharge piping was measured with a magnetic flowmeter. Outputs from the magnetic flowmeters were recorded on the datalogger.

\subsubsection{Pressure Measurement}

Grout pressure at the pump discharge was measured using an Iso-Spool ${ }^{*}$ system, which transmits pressure across a rubber diaphragm to both a liquid-filled

- Tradename of Ronningen-Petter Div., Dover Corp. Portage, Michigan. 

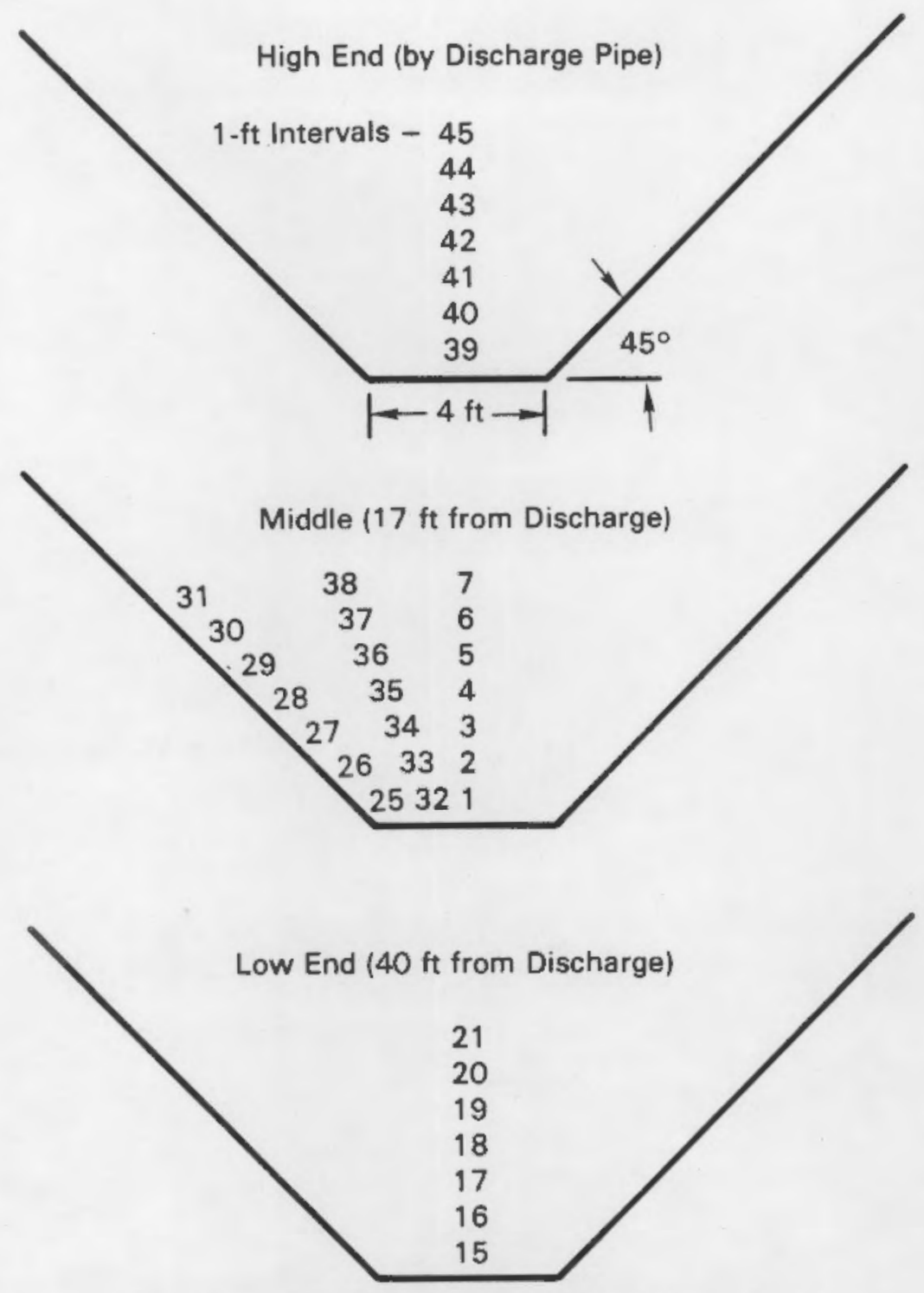

(Numbers Represent Thermocouple Identification)

FIGURE 2.12. Schematic of Trench Thermocouples

pressure gauge and a transducer. The datalogger recorded the transducer output and was programmed to shut the pump down if the pressure exceeded 125 psig.

\subsubsection{Miscellaneous Measurements}

Pump amperage and rpm were recorded on the datalogger. Data from the gravimetric dry blend feeder (weight loss rate) were recorded on the datalogger. Relative humidity in the trench was measured using a hand-held meter. 


\subsection{MATERIAL PREPARATION AND SAMPLING PROCEDURES}

This chapter describes the procedures used to prepare the simulated waste and dry blend. It also describes the sampling procedures used during the test.

\subsection{SYNTHETIC WASTE PREPARATION}

The simulated waste consists of equal volumes of aqueous phosphate and sulfate wastes. Phosphate waste is generated during the decontamination of $N$ Reactor. This waste's principal ingredient is phosphoric acid, which is neutralized with sodium hydroxide prior to storage. Sulfate waste results from the regeneration of ion-exchange columns used to clean water in spent fuel storage basins at $N$ Reactor. The major component of sulfate waste is sulfuric acid that has been neutralized with sodium hydroxide. Included in the sulfate waste is a third minor stream called "sandfilter backwash" which is mixed with the sulfate waste at a ratio of $50 \mathrm{~kg}$ of sludge per million liters of sulfate waste. The sandfilters remove solids from the process stream prior to the ion exchange columns.

Batches of simulated phosphate and sulfate wastes were prepared in an agitated stainless steel tank using the formula in Table 3.1 and then pumped to the waste feed tank. Prior to grout production, the synthetic waste was analyzed for $\mathrm{pH}$ and major cations and anions. Table 3.2 compares the target concentrations of major species to the measured concentration values. As shown, there is reasonable agreement between the target and the measured compositions. The measured calcium concentration was greater than the target value due to calcium in the tap water used to make up the waste. The iron level was lower than the target value, perhaps due to sampling deficiency (i.e., the sample was deficient in precipitate containing iron). The chioride level was higher than the target value, presumably due to contamination in the sodium hydroxide and/or sodium sulfate. However, in these concentration ranges, the discrepancy in the actual values as compared to the target values is not expected to affect leach resistance or curing of the grout.

Trace chemicals such as $\mathrm{Cr}$, As, Se, etc. were added in amounts that corresponded to analyses conducted on actual waste samples. The diethylthiourea 
TABLE 3.1. Formulas for Preparation of Phosphate and Sulfate Wastes

\begin{tabular}{|c|c|c|}
\hline Component & $\begin{array}{r}\text { Phosphate Waste } \\
(4000 \text {-Gal Batch) }\end{array}$ & $\begin{array}{c}\text { Sulfate Waste } \\
(4000-G a l \text { Batch) }\end{array}$ \\
\hline $\begin{array}{l}\text { Tap water } \\
\text { Turco } 4512 \mathrm{~A}-17 \\
\quad \text { (without inhibitor) } \\
1,3-0 \text { iethyl 2-thiourea } \\
\mathrm{Na}_{2} \mathrm{SO}_{4}\end{array}$ & $\begin{array}{l}25,000 \mathrm{lb} \\
102 \mathrm{gar} \\
1,817 \mathrm{~g} \\
0\end{array}$ & $\begin{array}{l}25,000 \mathrm{lb} \\
0 \\
0 \\
68,310 \mathrm{~g}\end{array}$ \\
\hline $\mathrm{As}_{2} \mathrm{O}_{3}$ & $0.061 \mathrm{~g}$ & $0.08 \mathrm{~g}$ \\
\hline $\mathrm{BaCO}_{3}$ & $1.12 \mathrm{~g}$ & $8.18 \mathrm{~g}$ \\
\hline $\mathrm{Cd}\left(\mathrm{NO}_{3}\right)_{2} \cdot 4 \mathrm{H}_{2} \mathrm{O}$ & $0.1 \mathrm{~g}$ & $2.271 \mathrm{~g}$ \\
\hline $\mathrm{Cr}\left(\mathrm{NO}_{3}\right)_{3} \cdot 9 \mathrm{H}_{2} \mathrm{O}$ & $167 \mathrm{~g}$ & $1,105 \mathrm{~g}$ \\
\hline $\mathrm{Hg}\left(\mathrm{NO}_{3}\right)_{2}$ & $0.14 \mathrm{~g}$ & $0.40 \mathrm{~g}$ \\
\hline $\mathrm{H}_{2} \mathrm{SeO}_{3}$ & $0.074 \mathrm{~g}$ & $0.098 \mathrm{~g}$ \\
\hline $\mathrm{AgNO}_{3}$ & $0.288 \mathrm{~g}$ & $1.97 \mathrm{~g}$ \\
\hline $\mathrm{CuSO}_{4} \cdot 5 \mathrm{H}_{2} \mathrm{O}$ & $4.088 \mathrm{~g}$ & $18.2 \mathrm{~g}$ \\
\hline $\mathrm{Fe}\left(\mathrm{NO}_{3}\right)_{3} \cdot 9 \mathrm{H}_{2} \mathrm{O}$ & $17,411 \mathrm{~g}$ & $1,696 \mathrm{~g}$ \\
\hline $\mathrm{Fe}_{2}\left(\mathrm{SO}_{4}\right)_{3}$ & $1,968 \mathrm{~g}$ & $24,224 \mathrm{~g}$ \\
\hline $\mathrm{MnSO}_{4} \cdot \mathrm{H}_{2} \mathrm{O}$ & $999 \mathrm{~g}$ & $115 \mathrm{~g}$ \\
\hline $\mathrm{ZnSO}_{4} \cdot 7 \mathrm{H}_{2} \mathrm{O}$ & $47 \mathrm{~g}$ & $2,574 \mathrm{~g}$ \\
\hline $\mathrm{Pb}\left(\mathrm{NO}_{3}\right)_{2}$ & $1.075 \mathrm{~g}$ & $19.7 \mathrm{~g}$ \\
\hline $\mathrm{Ni}\left(\mathrm{NO}_{3}\right)_{2} \cdot 6 \mathrm{H}_{2} \mathrm{O}$ & $139 \mathrm{~g}$ & $227 \mathrm{~g}$ \\
\hline $\mathrm{Ca}\left(\mathrm{NO}_{3}\right)_{2} \cdot 4 \mathrm{H}_{2} \mathrm{O}$ & $197 \mathrm{~g}$ & 0 \\
\hline $\mathrm{CaSO}_{4} \cdot 0.5 \mathrm{H}_{2} \mathrm{O}$ & 0 & $1,105 \mathrm{~g}$ \\
\hline $\mathrm{KNO}_{3}$ & 0 & $303 \mathrm{~g}$ \\
\hline $\mathrm{Al}\left(\mathrm{NO}_{3}\right)_{3} \cdot 9 \mathrm{H}_{2} \mathrm{O}$ & 0 & $3,634 \mathrm{~g}$ \\
\hline $\mathrm{NaF}$ & $394 \mathrm{~g}$ & $1,332 \mathrm{~g}$ \\
\hline $\mathrm{NaCl}$ & $545 \mathrm{~g}$ & $999 \mathrm{~g}$ \\
\hline $\mathrm{NaOH}$ flakes & $535.2 \mathrm{~kg}$ & $22.2 \mathrm{~kg}$ \\
\hline Tap water & to 4000 -gal level & to $4000-\mathrm{gal}$ level \\
\hline
\end{tabular}


TABLE 3.2. Target and Measured Concentrations of Simulated PSW

\begin{tabular}{|c|c|c|}
\hline Component & $\begin{array}{c}\text { Target } \\
\text { Concentration, } \\
\text { ppb } \\
\end{array}$ & $\begin{array}{l}\text { Measured } \\
\text { Concentration, } \\
\text { ppb (one analysis) }\end{array}$ \\
\hline \multicolumn{3}{|l|}{ Cations } \\
\hline Al & 8,600 & 8,100 \\
\hline As & 4 & below detection limit of 80 \\
\hline $\mathrm{Ag}$ & 50 & not analyzed \\
\hline $\mathrm{Ba}$ & 200 & below detection limit of 2 \\
\hline $\mathrm{Ca}$ & 11,000 & 22,000 \\
\hline $\mathrm{Cd}$ & 30 & below detection limit of 4 \\
\hline $\mathrm{Cr}$ & 5,500 & 3,500 \\
\hline $\mathrm{Cu}$ & 200 & 500 \\
\hline $\mathrm{Fe}$ & 329,000 & 170,000 \\
\hline $\mathrm{Hg}$ & 10 & not analyzed \\
\hline K & 3,900 & below detection limit of 300 \\
\hline Mn & 12,000 & 8,400 \\
\hline $\mathrm{Na}$ & no target & $12,600,000$ \\
\hline $\mathrm{Ni}$ & 2,400 & 1,500 \\
\hline $\mathrm{Pb}$ & 400 & below detection limit of 60 \\
\hline $\mathrm{Se}$ & 3 & not analyzed \\
\hline Si & no target & 8,900 \\
\hline $\mathrm{Zn}$ & 19,800 & 17,000 \\
\hline \multicolumn{3}{|l|}{ Anions } \\
\hline $\mathrm{Cl}$ & 31,000 & 220,000 \\
\hline $\mathrm{F}$ & 26,000 & $<50,000$ \\
\hline $\mathrm{PO}_{4}$ & $13,700,000$ & $11,600,000$ \\
\hline $\mathrm{NO}_{3}$ & 385,000 & 400,000 \\
\hline $\mathrm{SO}_{4}$ & $2,200,000$ & $2,000,000$ \\
\hline $\mathrm{pH}$ & $11.5-12.5$ & 12.41 \\
\hline
\end{tabular}


is a corrosion inhibitor that is added to the decontamination agent (Turco prior to decontamination of $\mathrm{N}$ Reactor.

Two 4000-gal batches and one 3000-gal batch of each waste were prepared to provide a total of 22,000 gallons of simulated waste.

\subsection{DRY BLEND PREPARATION}

The dry blend was prepared at the DMRHF. The dry blend was tested at PNL prior to the pilot-scale test to determine the desired mix ratio for the test (see Section 4.3.1). The dry-blend formulation is listed in Table 3.3.

The dry blend for the pilot-scale test was transported to PNL in trailers with 1000-ft ${ }^{3}$ capacities. Three trailers of dry blend were used during the test.

\section{TABLE 3.3. Dry Blend Formulation}

\begin{tabular}{lc} 
Component & Weight Percent \\
\cline { 1 - 1 } Portland Cement, I-II & 41 \\
Flyash, ASTM Class F & 40 \\
Attapulgite Clay & 11 \\
Indian Red Pottery Clay & 8
\end{tabular}

\subsection{SAMPLING DURING THE TEST}

To statistically determine grout homogeneity, it was necessary to obtain many samples of cured grout, grout slurry, simulated PSW, and dry blend. This section describes the system that was developed to extract undisturbed cores of grout from the monolith. The frequency of sample collection is described, as well as tests planned for the samples.

\subsubsection{Grout Core Sampler}

In order to obtain representative samples of grout from the pilot-scale monolith, PNL designed and tested samplers to extract grout without requiring core-drilling. The final design used in the pilot-scale test is depicted in

- Tradename of Purex Corporation. 
Figure 3.1. The sampler consists of a PVC sample tube in a steel pipe. Two 0 -ring seals in the annulus at the base of the sampler prevent grout from entering the annulus. As the sampler is inserted into grout that has not set, grout flows into the sample tube.

The sampler was built with standard materials (2-in., Schedule 40 PVC pipe and 2.5-in., Schedule 10 carbon steel pipe). The system was sized to provide adequate sample size while minimizing disturbance to the grout as it was inserted. The grout cures in the PVC tube and around the steel pipe. After a

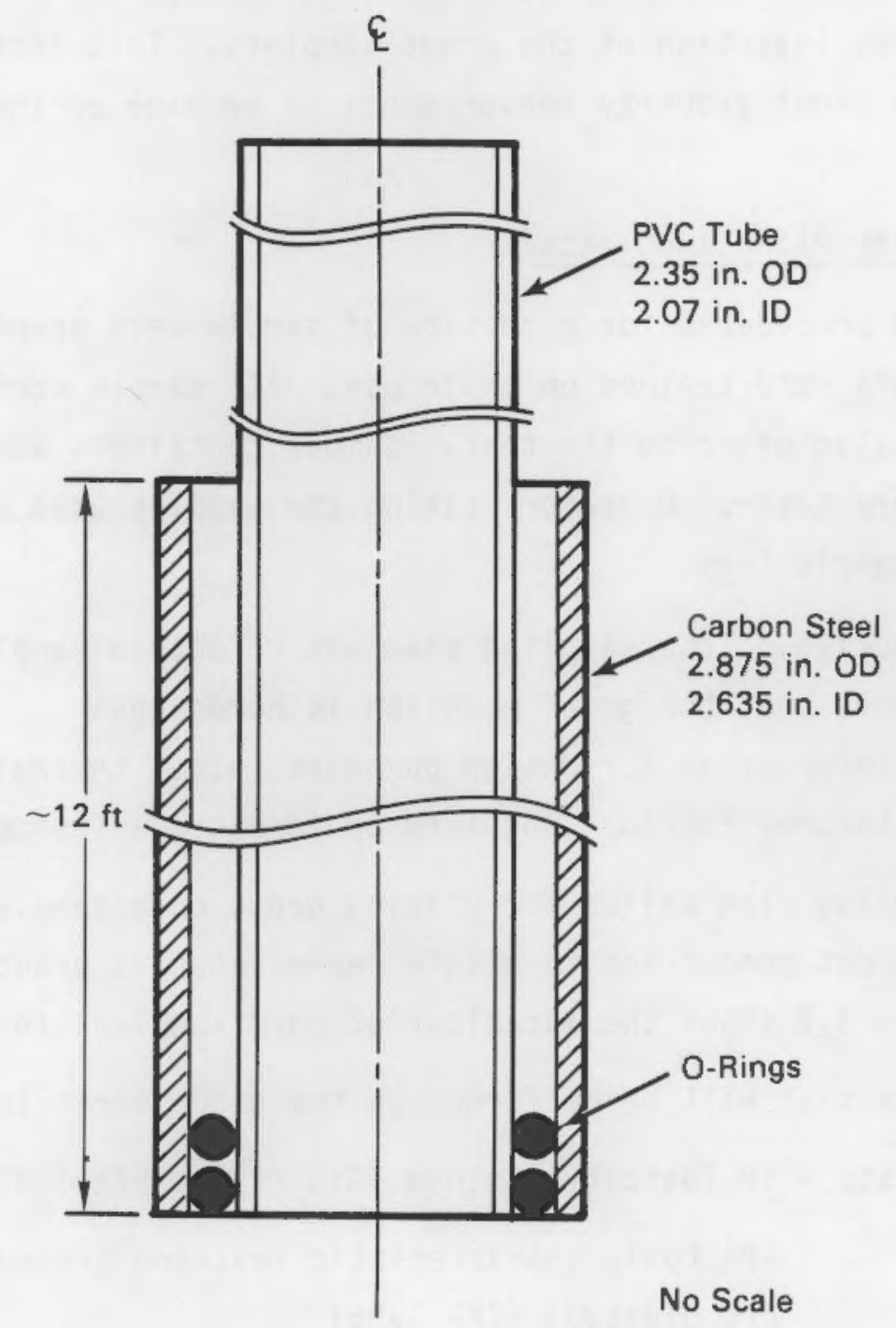

FIGURE 3.1. Grout Sampler Designed for Pilot-Scale Test 
specified curing time, the PVC tube is lifted from the steel pipe and the grout. remains in the PVC. Based on the expected tensile strength of the grout, less than 100 pounds of force should be required to fracture the grout at the end of the sampler in order to remove the PVC tube from the monolith.

Measurements taken after the samplers were removed from the monolith show a higher level of grout in some sampler tubes than expected. The level of grout in the samplers is expected to be the same level as the grout in the monolith that they were taken from. The fact that the levels of grout in the samplers were higher than expected implies that some upset to the grout occurred during insertion of the grout samplers. This factor may have some effect on the grout property measurements to be made on the grout in the samplers.

\subsubsection{Sampling Plans and Tests}

Sampling procedures for each type of sample were prepared prior to the test; operators were trained on their use. All sample containers were cleaned, dried, and sealed prior to the test. Sample containers were labeled and sealed as samples were taken. Operators taking the samples used chain of custody records and sample logs.

The objective of the sampling plan was to obtain samples to:

- demonstrate that the grout monolith is homogenous

- provide information for design purposes (e.g., thermal properties)

- provide information for long-term performance assessment issues.

The sampling plan called for placing grout core samplers after 10 and 24 hours of grout production to obtain representative grout cores from the monolith. Figure 3.2 shows the locations of core samplers in the monolith.

The tests that will be performed on the grout cores include:

- leach tests - EP Toxicity; Method 1310 (U.S.. EPA 1982)

- EPA toxic characteristic leaching procedure (when promulgated) (CFR 1986)

- MCC-1 (Mendel 1985) 

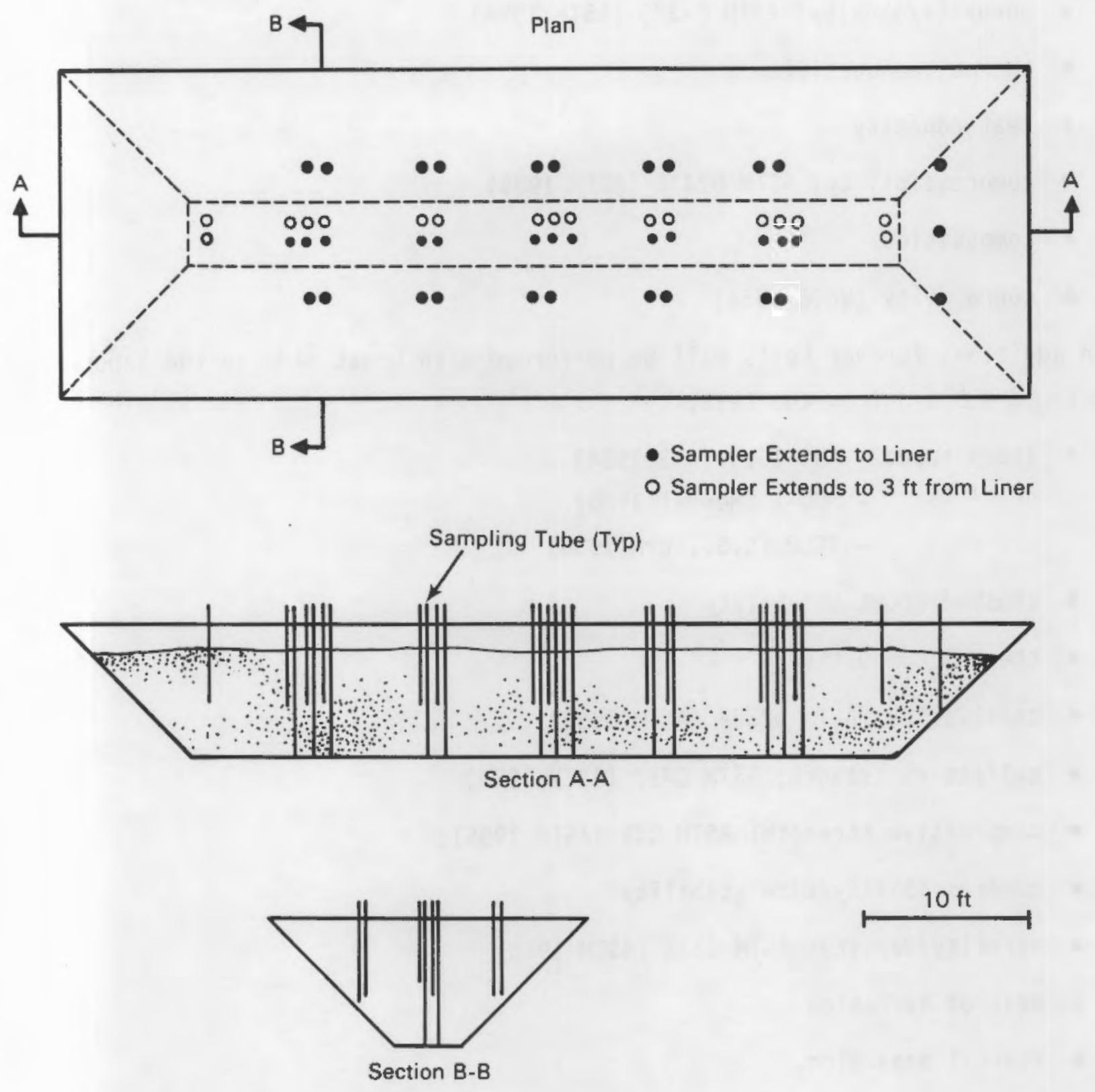

FIGURE 3.2. Location of Samplers in the Monolith

- ANS 16.1 (ANS 1984)

- oil and grease leachability Method 413.1 (U.S. EPA 1982)

- unconfined compressive strength; ASTM C-39 (ASTM 1985)

- capillarity; ASTM D2325 (ASTM 1985) 
- porosity/density; ASTM C-373 (ASTM 1985)

- thermal conductivity

- heat capacity

- compressibility; ASTM D2435 (ASTM 1985)

- composition

- corrosivity (WDDE 1984)

In addition, further tests will be performed with grout made in the laboratory using dry blend from the test:

- leach tests - ANS 16.1 (ANS 1984)

- MCC-1 (Mendel 1985)

- TCLP (U.S.. EPA 1986)

- crushed grout solubility

- thermal conductivity

- capillarity; ASTM D2325 (ASTM 1985)

- sulfate resistance; ASTM C452 (ASTM 1985)

- compressive strength; ASTM C39 (ASTM 1985)

- compressibility/size stability

- porosity/density; ASTM C373 (ASTM 1985)

- heat of hydration

- thermal expansion.

In addition to the cores of cured grout obtained after the test, numerous samples were collected during the test at predetermined production times. Dry blend was sampled at the feed bin; subsequent analyses planned are $X$-ray diffraction (for determination of mineralogy), grain size, and cations (by inductively coupled plasma (ICP) spectrometry). Upstream of the mixer, PSW was sampled; its $\mathrm{pH}$ was measured immediately after sampling. Subsequent tests of the waste samples will include total suspended solids, EP toxicity, total organic carbon, and cation and anion analyses. Grout slurry was sampled at the 
mixer discharge and at the trench discharge. Tests conducted on the grout slurry included rheology, bleed water, sonic velocity, penetration resistance, and compressive strength. Bleed water samples were collected from the pilotscale trench during the month following grout production. Bleed water was analyzed for EP toxicity, pH, total organic carbon, total oil and grease, anions, cations, and total organic carbon.

The results of most of the analyses of samples will be documented in a separate report. 



\subsection{RESULTS}

This chapter presents results from the pilot-scale test to date. The results focus primarily on equipment performance, behavior of grout in the trench, and the rheology of the grout produced in the test. Detailed chemical analyses of grout, dry blend, and simulated waste will be documented in a subsequent report to be published in 1987, along with data on monolith homogeneity and cured grout properties.

\subsection{SUMMARY STATISTICS}

Pilot-scale grout production was initiated at 9:11 a.m. on July 29, 1986 . Production ceased at $8: 16 \mathrm{p} . \mathrm{m}$. on July 30 . Total production time during this test was 24 hours. About 7 hours of down time occurred in the first 12 hours of the test due to flooding of dry blend through the feeder and subsequent plugging of the continuous mixer. After 12 hours, the operation went more smoothly; however, occasional flooding of dry blend through the feeder caused down times of up to 30 minutes. Section 4.5 .1 describes the flooding of dry blend in detail.

About 16,000 gallons of simulated waste and about 115,000 pounds of dry blend were used to produce about 22,000 gallons of grout. The volume of the grout was $38 \%$ greater than the volume of the PSW used to produce the grout. The average mix ratio was 7.2 pounds of dry blend per gallon of PSW. The average grout level in the trench was 6 feet.

The density of the grout slurry averaged $11.47 \mathrm{lb} / \mathrm{gal}(0.16$ standard deviation). No significant difference was observed in the specific gravity of the grout at the surge tank and at the discharge from the piping to the trench (see Figure 4.1). It is concluded that insignificant deaeration of the grout occurred in the surge tank.

All samples (nearly 600) were taken at their scheduled times. All grout core samplers (a total of 53) were placed in the fresh grout at the planned times and sufficient core length was obtained in each sampler to produce the required samples for statistical determination of homogeneity and for other tests to resolve design, safety, and performance assessment issues. 


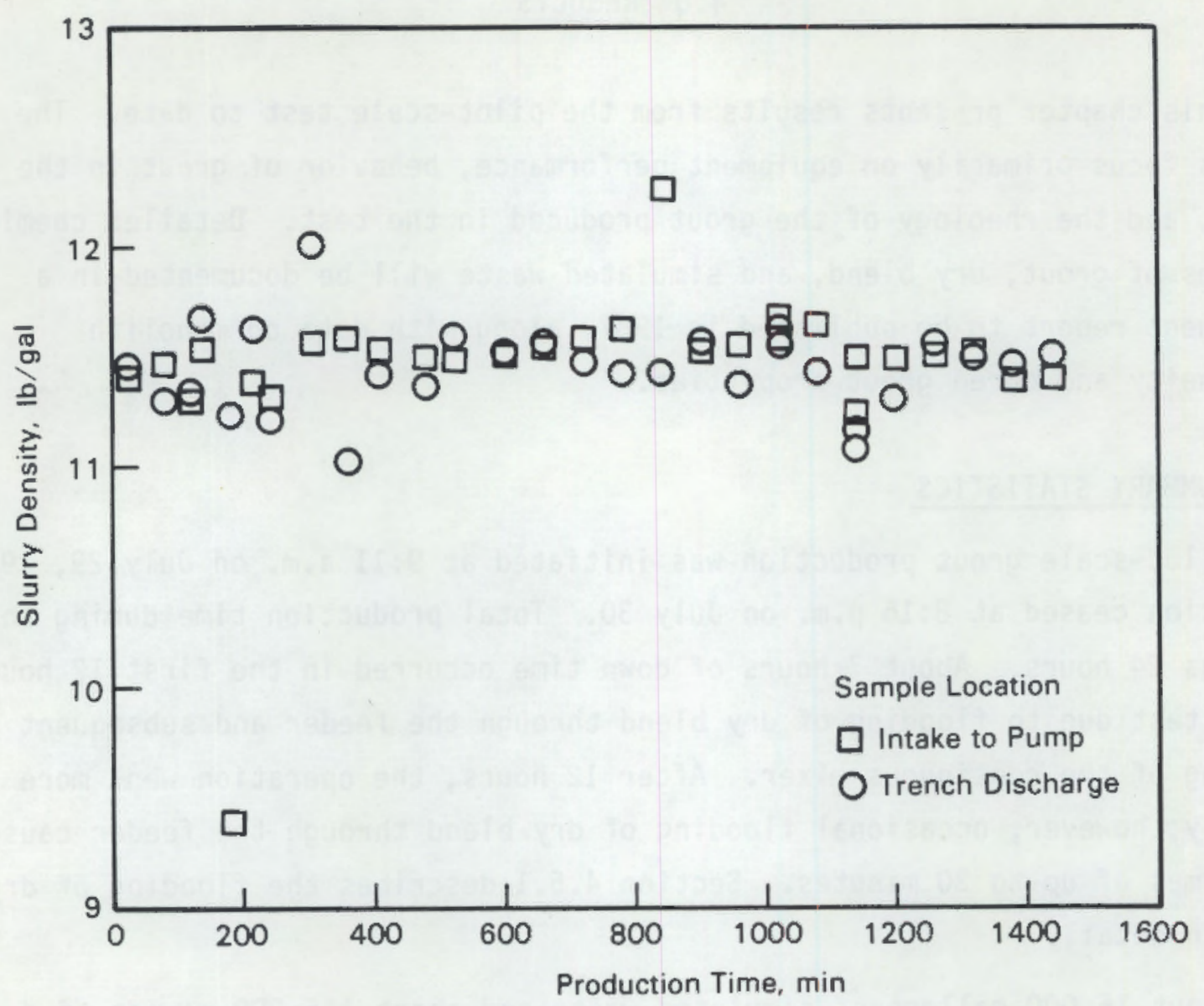

FIGURE 4.1. Specific Gravity of Grout at Surge Tank and at Discharge to Trench

\subsection{BEHAVIOR OF GROUT IN THE TRENCH}

Radioactive grout at Hanford will be pumped to underground concrete vaults for final disposal. Each vault will hold about 1.4 million gallons of grout. The planned interior dimensions of a grout vault are 125 feet long by 50 feet wide by 35 feet deep. The pilot-scale test provided valuable information as to how PSW grout will behave in a vault. Specifically, the test provided information on grout flow angles, temperature rise, separated liquid generation, setting characteristics, and degree of cracking. This section of the report presents the results of the pilot-scale test that pertain to the behavior of grout in the trench. (One topic not presented here is homogeneity, which will be covered in a subsequent report.) 
In this report, the end of the trench nearest the grout discharge point will be referred to as the high end. The end of the trench farthest from the discharge point will be referred to as the low end.

\subsubsection{Flow Angle}

In the proposed vault, grout will flow from the point of discharge out to 67 feet. Pilot-scale tests performed at PNL in 1984 and 1985 demonstrated that grout would fill a given space at a flow angle greater than zero (i.e., the grout is not self-leveling). The flow angle will affect the capacity of a vault; therefore, the flow angle required measurement on a larger scale.

The flow angle of the grout in the pilot-scale test is illustrated in Figure 4.2. The flow angle near the point where grout was discharged into the trench (the high end) was $0.6^{\circ}$. The flow angle increased to $2.4^{\circ}$ at the low end of the trench. The average flow angle of grout from the discharge point in the trench to the farthest point (49 feet away) was $1.4^{\circ}$, corresponding to a 14-in. difference in grout depth.

In a test performed in May of 1986, 4000 gallons of grout poured into a 40-ft-long by 4-ft-wide trench exhibited an overall flow angle of $2^{\circ}$ with some portions up to $3.5^{\circ}$. However, the mix ratio of this grout was higher (7.9 pounds of dry blend per gallon of waste) and the grout was visibly thicker. The grout flow angle in the disposal vault will be largely a function of the rheological properties of the grout as it is discharged to the vault.
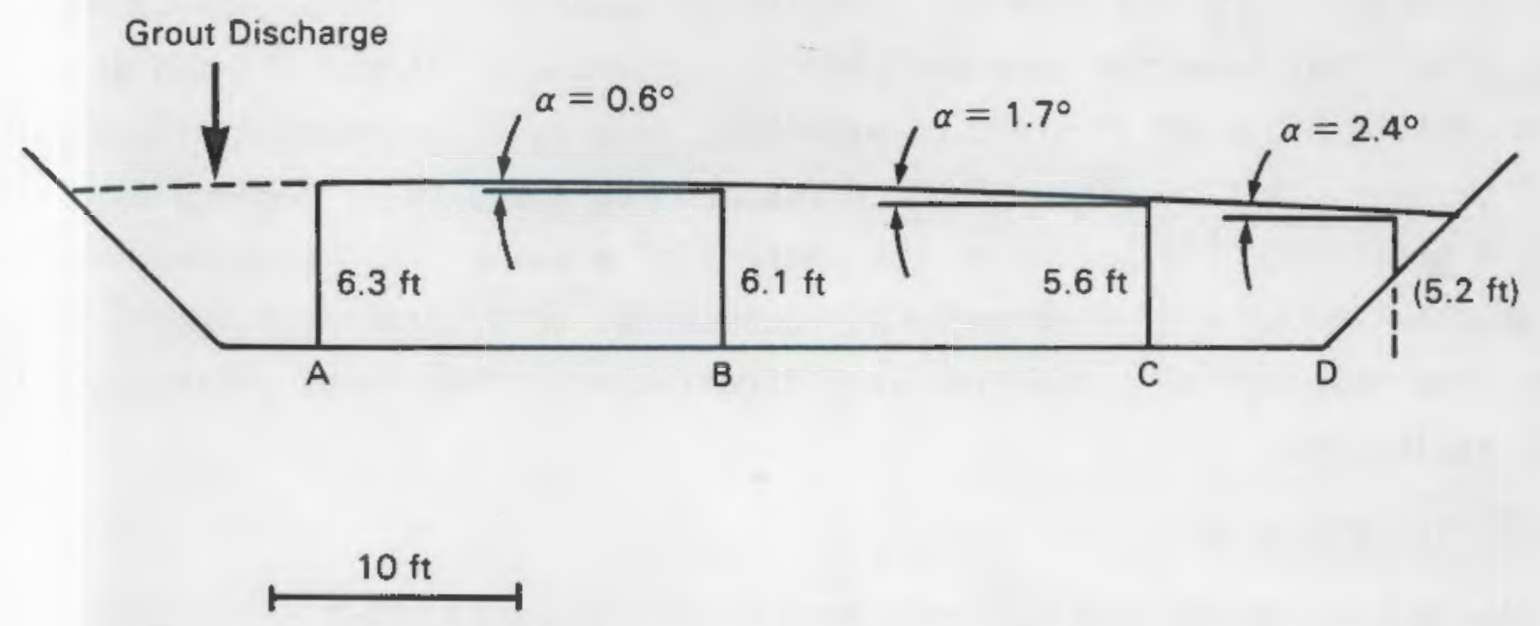

FIGURE 4.2. Grout Flow Angle in the Pilot-Scale Test 
Variations in the mix ratio and the degree of shear thickening that will occur in the piping will affect the flow angle. Because it is mandatory that the apparent viscosity of the grout at the discharge nozzle be low enough to maintain turbulent flow in the piping, such a grout should exhibit an acceptably low angle of flow.

To predict the flow angle of grout in a vauit, several assumptions are required. The major assumption is that the rheological properties of TGF grout. will be similar to those of the grout produced in the pilot-scale test. This assumption is reasonable in that the same dry blend, a chemically similar waste, and the same type of mixer and pump will be used. As discussed in Section 4.3.1, it will be necessary to control the mix ratio so that the grout flow rate exceeds the critical flow rate. A second assumption involves the extrapolation of the results of this test (in which the grout flowed 49 feet) to the actual case in which grout will flow 67 feet. As discussed in the next section, the grout flowed in thin sheets in relatively narrow channels that widened as the grout moved away from its point of addition to the trench. As the channel widens, the shear rate decreases. When the grout flows beneath separated liquid that collects on the surface of the grout, shear rate decreases further due to further lateral dispersion of the flow. As the shear rate decreases, the apparent viscosity increases, resulting in a greater flow angle.

Consequently, it is expected that the flow angles in the vaults will not be significantly greater than the flow angles observed in the pilot-scale test with grouts that have the same rheological properties. At the low end of a vault, a flow angle of $3^{\circ}$ might be expected, leading to an overall flow angle of $2^{\circ}$ or less. A flow angle of $2^{\circ}$ corresponds to a 2.3-ft difference in elevation of grout from the center to the corners of a vault. For conservative design, the use of a $5^{\circ}$ flow angle is recommended to provide contingency in the event that rheological properties vary significantly from those observed in the pilot-scale test.

\subsubsection{Flow Patterns}

No unusual grout flow patterns were observed in the pilot-scale test. The grout flowed in well-defined channels, with the channel width increasing with 
increasing flow distance, but with decreasing definition. A typical channel width at the high end of the trench was 1.5 feet.

The pilot-scale trench was 4 feet wide at the base, widening gradually to the top. At the end of the test, the grout had risen to the 6 - $\mathrm{ft}$ level where the trench width was 16 feet. (In contrast, the width of a disposal vault will be 50 feet.) The grout flowed in one channel until the level in that channel increased to the point that the stream diverted to a lower channel. Because the grout did not flow over the entire available area at any one point in time, the difference in trench and vault width is not expected to impact flow characteristics. Therefore, similar flow behavior is expected in a disposal vault. However, due to the greater production rate for grout disposal in the actual vaults, the grout will probably flow in wider, and perhaps deeper, channels at about the same velocity as observed in the pilot-scale test.

The grout produced in the pilot-scale test was thinner than that produced in the test in May of 1986. As a consequence, the grout surface was quite smooth compared to the jagged surface observed in the May test. Figures 4.3 and 4.4 compare the grout surfaces in the two tests.

In the earlier tests, large, deep masses of flowing grout (as opposed to thin, layered flow at the surface) had been observed. This observation gave rise to concern that the thermocouple bundles and/or the grout core samplers could be displaced from their installed orientations. Therefore the bundles and samplers were designed with anchors and braces to reduce this possibility. In the pilot-scale test, no displacement of thermocouple bundles or samplers was observed. Additionally, trench observers did not note any massive movements of grout during the test. This is not to say that massive movements did not occur, however, because the presence of the trench cover restricted viewing.

One other concern was that samplers placed after 10 hours of production might interfere with grout flow. However, insignificant interference was noted. At the end of production, no flow lines or cracking due to flow disturbance created by the samplers was noted. 


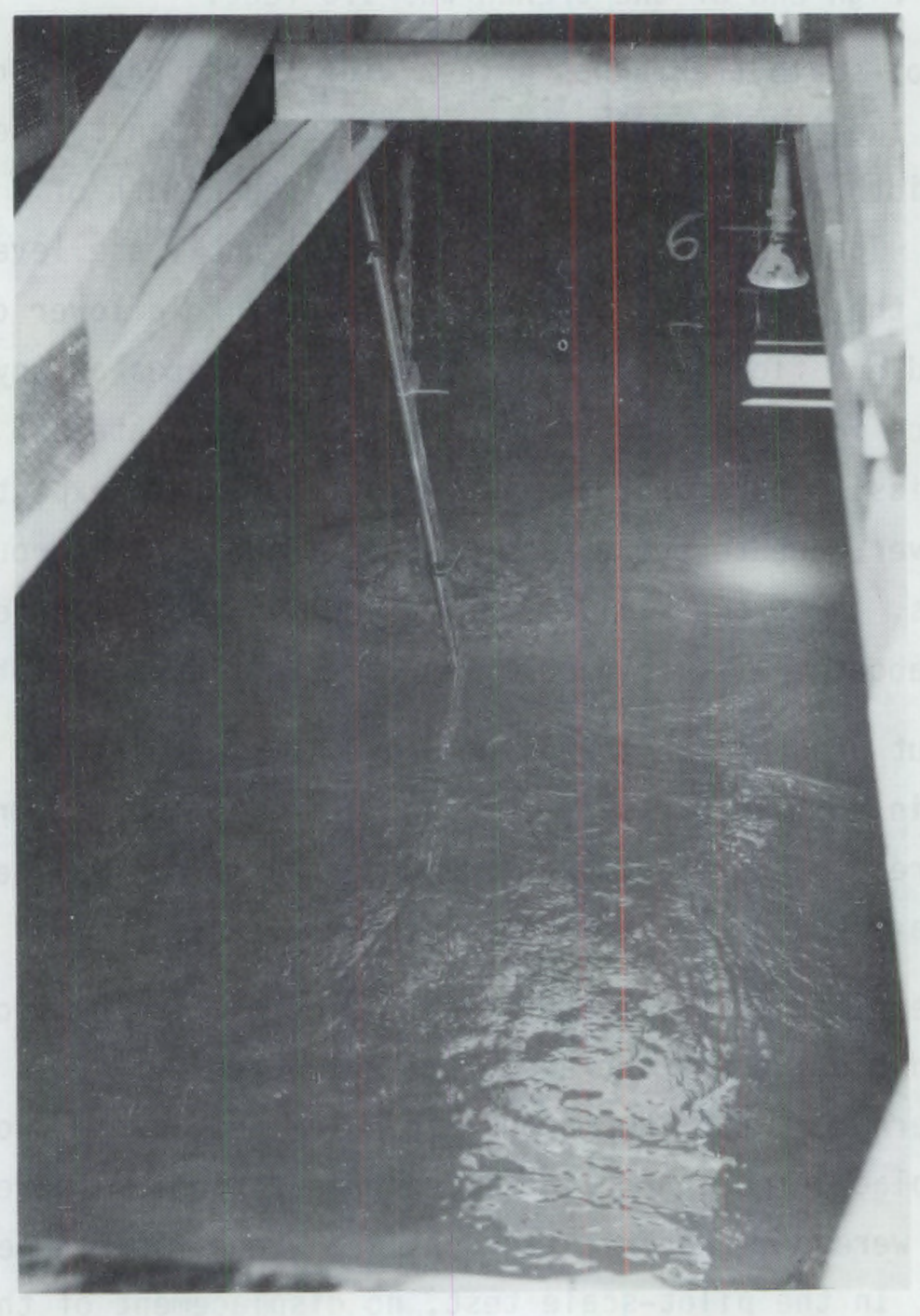

FIGURE 4.3. Grout Surface in Pilot-Scale Test

In summary, these flow pattern results indicate that grout will flow primarily in thin layers in well-defined channels that widen at increasing distances from the addition point. The grout surface is expected to be smooth if the critical flow characteristics match those of the grout produced in this test. If the vault cameras have enough resolution to observe the texture of 


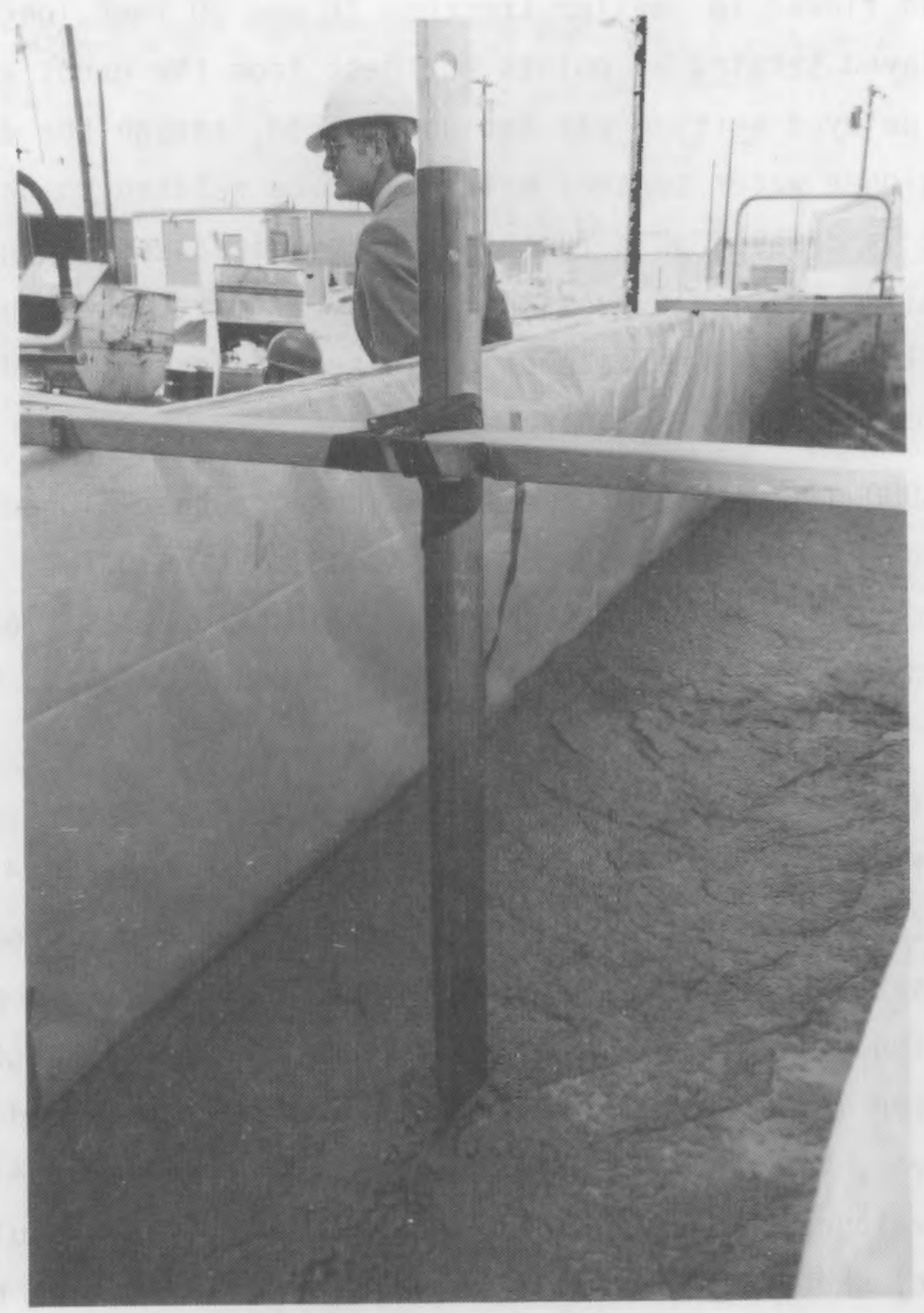

FIGURE 4.4. Grout Surface in Previous Test with Higher Mix Ratio

the grout surface, the TGF operators might be able to use this information as an indicator that the yrout is too thick and that adjustments are required. If the vault design calls for level probes or other probes that penetrate into the grout, these devices should be anchored. Although massive movements of grout were not observed in this test, the potential for such movements exists. 


\subsubsection{Grout Setting}

Tests performed in 1984 and 1985 with simulated PSW grout showed that grout that had flowed in smaller trenches ( 8 and 20 feet long, respectively) exhibited delayed setting at points furthest from the grout addition point. The cause of delayed setting was not understood, though the delayed-set grout exhibited a higher water content which could be related to the problem. If grout setting is delayed as a function of the distance that grout flows, then vault disposal design could be significantly affected. The pilot-scale test permitted evaluation of the rate of grout setting over flow distances approaching to those expected in a disposal vault.

In the 4000-gal test performed in May, grout that flowed 40 feet exhibited slightly lower set rates than grout near the addition point. However, the grout achieved penetration resistances exceeding 700 psi at all points within 7 days after production. Thus some of the concern of delayed setting was alleviated.

In the pilot-scale test, the simulated PSW grout set slightly slower at the low end of the trench. This slower setting was indicated by the ease of placement of the core samplers at the low end after grout production. However, the delay in setting was not significant enough to warrant concern regarding the vault design. It was not possible to quantify the strength of the grout via penetrometer measurements due to the high temperature and humidity in the trench. However, two days after production, the grout at the low end of the trench had developed enough strength so that a steel tube could not be pushed into the grout. Future compressive strength and penetration resistance tests on core samples will provide information as to the relative strength of the grout as a function of flow distance.

The delay in setting observed in prior tests can probably be explained by hydration kinetics and heat loss. The rate of hydration (and therefore the rate of strength development) increases with temperature. In previous smaller tests, the mass of grout undergoing hydration was much smaller than in the 4000-gal test and pilat-scale test. The heat of reaction was therefore more easily dissipated by the small trenches used in the smaller tests. The separated liquid that collected at the low end of trenches represented an 
additional heat sink in both small and larger tests. Thus, lower temperatures explain why cure rates are slower at locations where separated liquid existed in smaller-scale tests. In a vault, the grout volume-to-vault surface area will be much lower than that of the pilot-scale test ( $8 \mathrm{ft}$ versus $1.4 \mathrm{ft}$ ). Furthermore, the buried vault will be better insulated on all sides by the surrounding earth and cover. Therefore, grout temperatures and setting rates should be higher than those observed in the pilot-scale test. In summary, the pilot-scale test demonstrated that setting rates will be sufficiently high that the required compressive strength (50 psi) should be achieved at all points within several days following production.

\subsubsection{Separated Liquid}

Separated liquid develops on the surface of PSW grout soon after the grout is produced. However, PSW grout was formulated to reabsorb all separated liquid within 28 days after production. Complete reabsorption occurs when the reference grout is produced in the laboratory and cast in small containers. However, in a large casting, separated liquid will pool in the low corners, such as in a vault. Because the separated liquid is not distributed over the entire surface of large castings, reabsorption may occur more slowly. The pilot-scale test permitted the evaluation of the amount and composition of separated liquid that can be expected in a sealed vault, and to determine whether the separated liquid will completely reabsorb.

The separated liquid in the pilot-scale trench covered approximately half the surface area of the monolith and accumulated in the end farthest from the discharge point. Figure 4.5 shows calculated volumes of separated liquid in the trench as a function of the number of days after production. About 1400 gallons of separated liquid were present in the trench two days after production. By extrapolation of data, as much as 1600 gallons may have been present immediately after production. Approximately 80 gallons of the separated liquid are attributed to flush water that was pumped to the trench during the production period and immediately thereafter. After 28 days, 27 gallons of separated liquid remained. All separated liquid was reabsorbed within 30 days. 


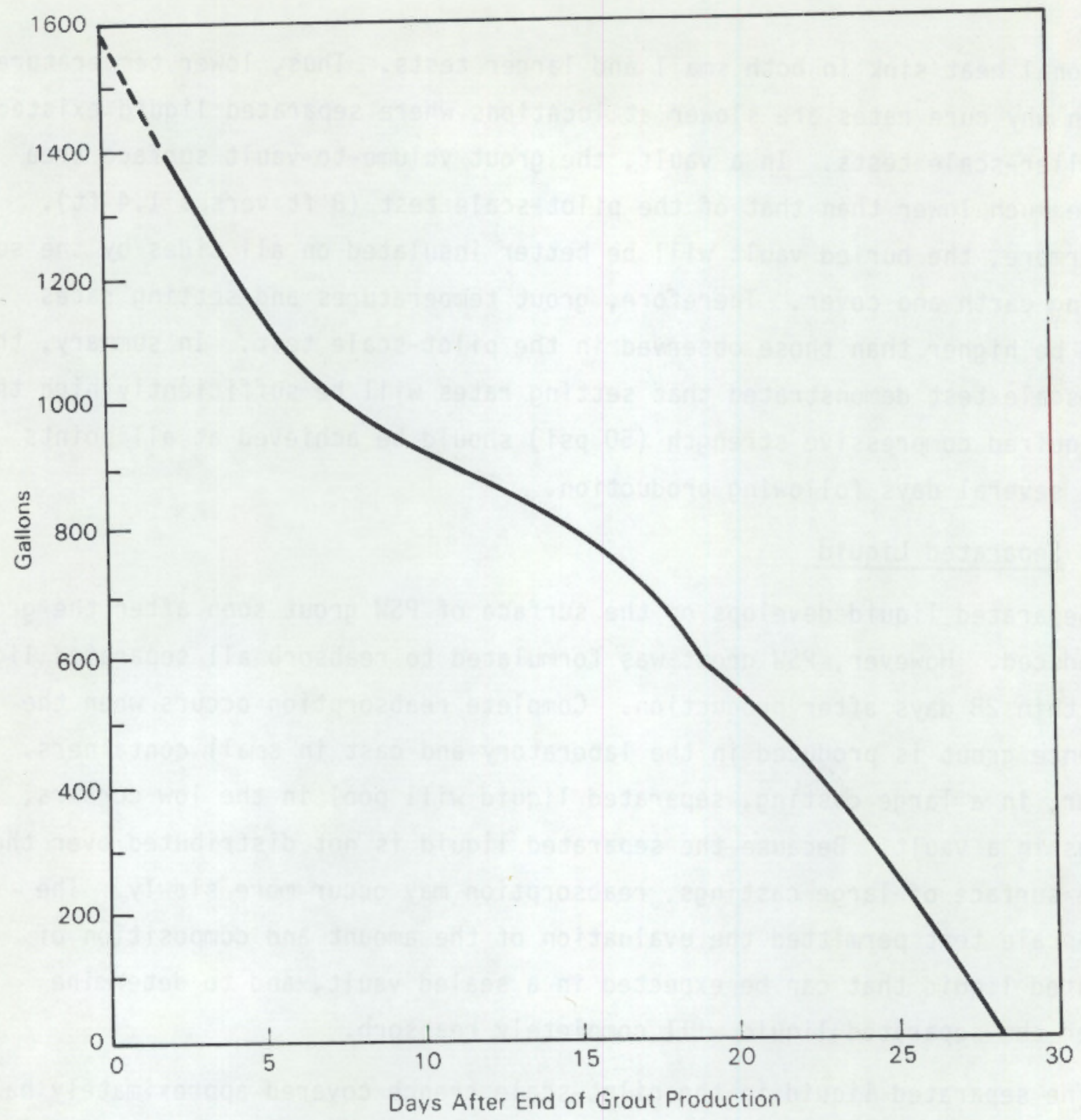

FIGURE 4.5. Volume of Separated Liquid

The decline in volume of separated liquid is primarily attributed to reabsorption by the grout. Undoubtedly, some liquid was lost by absorption into the wood cover and the soil in the anchor trench, by sampling, by vapor loss during viewing, and through minor leaks in the vapor barrier cover. It is estimated that these losses do not exceed 20 gallons, or $1.5 \%$ of the initial volume of separated liquid. 
The reabsorption rate was highest during the first seven days after production (about 95 gallons per day). This corresponds to the period when grout temperatures were the highest and when the hydration rate was the greatest. After seven days, reabsorption rates subsequently fell to about 60 gallons per day.

Table 4.1 presents preliminary chemical analysis of the separated liquid as compared to the average synthetic waste feed analyses. The $\mathrm{pH}$ of the separated liquid is greater than that of the waste due to hydration of 1 ime in the cement. Organic carbon, nitrate, and sodium are approximately the same concentration in both samples. Iron and phosphate are lower in the separated liquid due to precipitation of iron phosphate in the waste and incorporation of the precipitate in the grout. Sulfate, however, appears to concentrate in the separated liquid. More detailed analyses of separated liquid will be available in the future.

During production, a layer of immiscible fluid was floating on the separated liquid. However, this layer (perhaps containing tributyl phosphate) disappeared after five days. Apparently, it dissipated due to dispersion in the separated liquid. It is possible that as condensate refluxed in the trench and as liquid saturated with tributyl phosphate was being reabsorbed by the grout, the layer was totally dissolved.

TABLE 4.1. Comparison of the Compositions of PSW and Separated Liquid

\begin{tabular}{|c|c|c|}
\hline Item & $\begin{array}{l}\text { PSW } \\
\text { (With Precipitate) } \\
\end{array}$ & Separated Liquid \\
\hline $\mathrm{pH}$ & 12.2 & $13.1-13.2$ \\
\hline TOC, $\mathrm{ppm}$ & $370-538$ & $405-573$ \\
\hline $\mathrm{SO}_{4}, \mathrm{ppm}$ & 2,000 & 7,200 \\
\hline $\mathrm{PO}_{4}, \mathrm{ppm}$ & 11,600 & $1,500-560$ (decreasing with time) \\
\hline $\mathrm{NO}_{3}, \mathrm{ppm}$ & 400 & $350-380$ \\
\hline $\mathrm{Na}, \mathrm{ppm}$ & 12,600 & 11,000 \\
\hline $\mathrm{Fe}, \mathrm{ppm}$ & 170 & 1 \\
\hline
\end{tabular}


Based on results of the pilot-scale test, significant amounts of separated liquid can be expected in the grout vaults. The amount generated in the pilotscale test was $7 \%$ of the grout volume. Laboratory measurements of grout made from a dry blend and waste from the pilot-scale test showed a separated liquid volume to grout volume from 15-16\%. The difference in the laboratory grouts and pilot-scale grouts can be contributed to the type of mixing and the storage time of the dry blend. All the liquid in the pilot-scale test was reabsorbed into the grout in less than 30 days. Factors that will affect the amount of separated liquid in a vault include mix ratio, attapulgite characteristics, and flushing requirements. The removal of separated liquid should not be required if the separated liquid volume in a vault is less than $7 \%$ of the grout volume.

\subsubsection{Cracking}

The development of cracks in the grout is of interest because a high amount of cracking can significantly increase the surface area available for leaching, which could impair the ability of the grout to immobilize the waste.

The grout monolith was inspected on a regular basis to monitor crack development. The development of cracks was low in comparison with the level of cracking observed in the test performed in May. Cracks in the monolith were primarily parallel to the direction of the flow of the grout. The cracks appeared between the second and fourteenth day after the grout was produced and apparently grew little after they were first noticed. The maximum crack width appeared to be less than 0.25 inch. Cracks were most frequent at the high end of the trench.

Narrow cracks were observed on the fourteenth day after production, producing a crazed appearance on the grout surface. These cracks appeared to be less than 0.03 inches wide. They appear to cover the half of the monolith surface nearest the discharge nozzle.

The amount of cracking was much lower than observed in the 4000 -gal test. In that test, significant surface cracking developed at the low end of the trench, but essentially no cracks appeared at the high end. In the pilotscale test, cracks were most frequent near the grout addition point. 
It is not clear why the severity of cracking was so much greater in the 4000-gal test. One possible explanation for the difference is that the lower mix ratio used in the pilot-scale test yielded grout with a smoother surface. Therefore, there were not as many stress points where cracks seemed to develop. Another explanation is that insufficient water was available in the 4000-gal test. However, because cracking was just as frequent in a portion of the trench that was kept under water at all times, it is doubtful that insufficient water was the cause for cracking. A third possible explanation was that at the low end of the 4000-gal trench, where the liquid level was close to or above the grout surface, the grout was not as dense. Therefore, cracks formed when shrinkage that accompanies curing occurred. However, this explanation is not supported by the pilot-scale test in which crack development at the low end of the trench was minimal.

The actual reason for the difference in cracking frequency between the two tests may be a combination of these explanations. However, the lower level of cracking observed in the pilot-scale test seems to be attributable to the lower mix ratio used. Thus, lower mix ratios seem to yield less cracking as well as lower angles of flow and lower potential for plugged lines.

Plans have been made to remove the monolith from the trench in FY 1987 and, in doing so, to further evaluate the degree of cracking that has occurred to provide data for assessing the long-term environmental performance of PSW grout.

\subsubsection{Temperature in the Monolith}

Temperatures at various locations in the monolith were monitored during grout emplacement and at least daily since then. Thermocouples were strategically located to permit the determination of the temperature rise in the monolith and the comparison of temperature profiles vertically, longitudinally, and laterally in the monolith.

The maximum temperature rise measured in the monolith was $37^{\circ} \mathrm{C}$ above the incoming grout temperature $\left(29^{\circ} \mathrm{C}\right)$. Thus, the maximum temperature measured was $66^{\circ} \mathrm{C}$ at the high end of the trench near the grout addition point. Temperature profiles at the high end of the trench are shown in Figure 4.6. It can be seen 


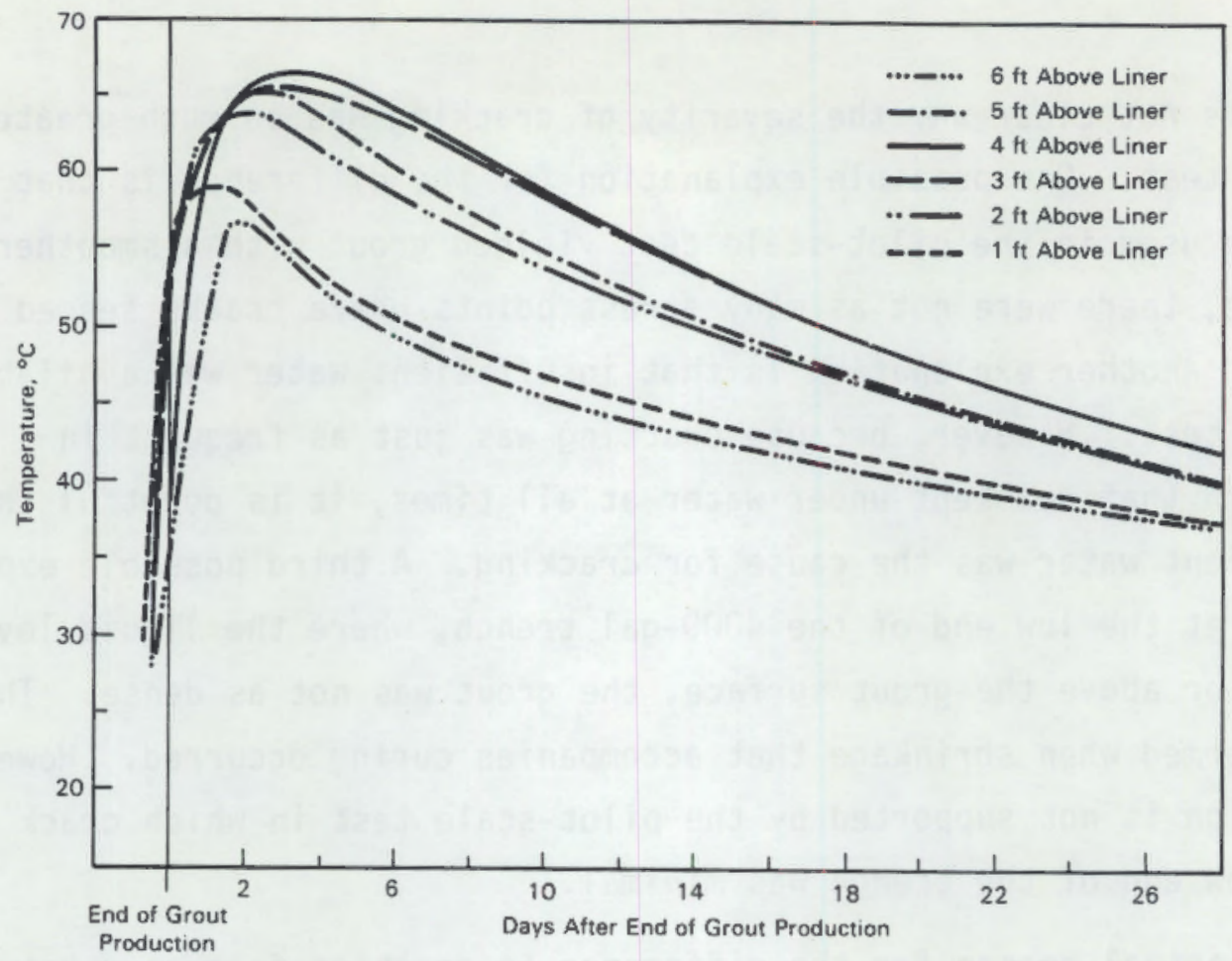

FIGURE 4.6. Temperature Profile - $2 \mathrm{ft}$ From Discharge Nozzle

that the temperature peaked three days after the grout was produced. As expected, the middle depth of the monolith reached the highest temperature.

Similar temperature profiles are provided in Figures 4.7 and 4.8 for the middle and low end of the trench. The profile 20 feet from the grout addition point is nearly identical to the profile at the addition point. In Figure 4.6 the thermocouple at the $6-\mathrm{ft}$ level is obviously affected by the fluctuating ambient temperature in the trench, because the thermocouple was very near the surface of the grout.

The profile at the low end of the trench ( 40 feet from the addition point) is similar in shape to the other locations. However, the maximum temperature at this location is about $60^{\circ} \mathrm{C}$. This lower temperature is probably due to the higher water content of the grout in this location as well as the smaller mass of the grout, which results in a higher rate of heat loss per mass of grout. For a comparison of temperatures longitudinally through the trench, refer to Figure 4.9, which depicts the temperature three feet above the liner at three trench locations. (The $3-\mathrm{ft}$ level exhibited the greatest temperature rise in each of the positions.) 


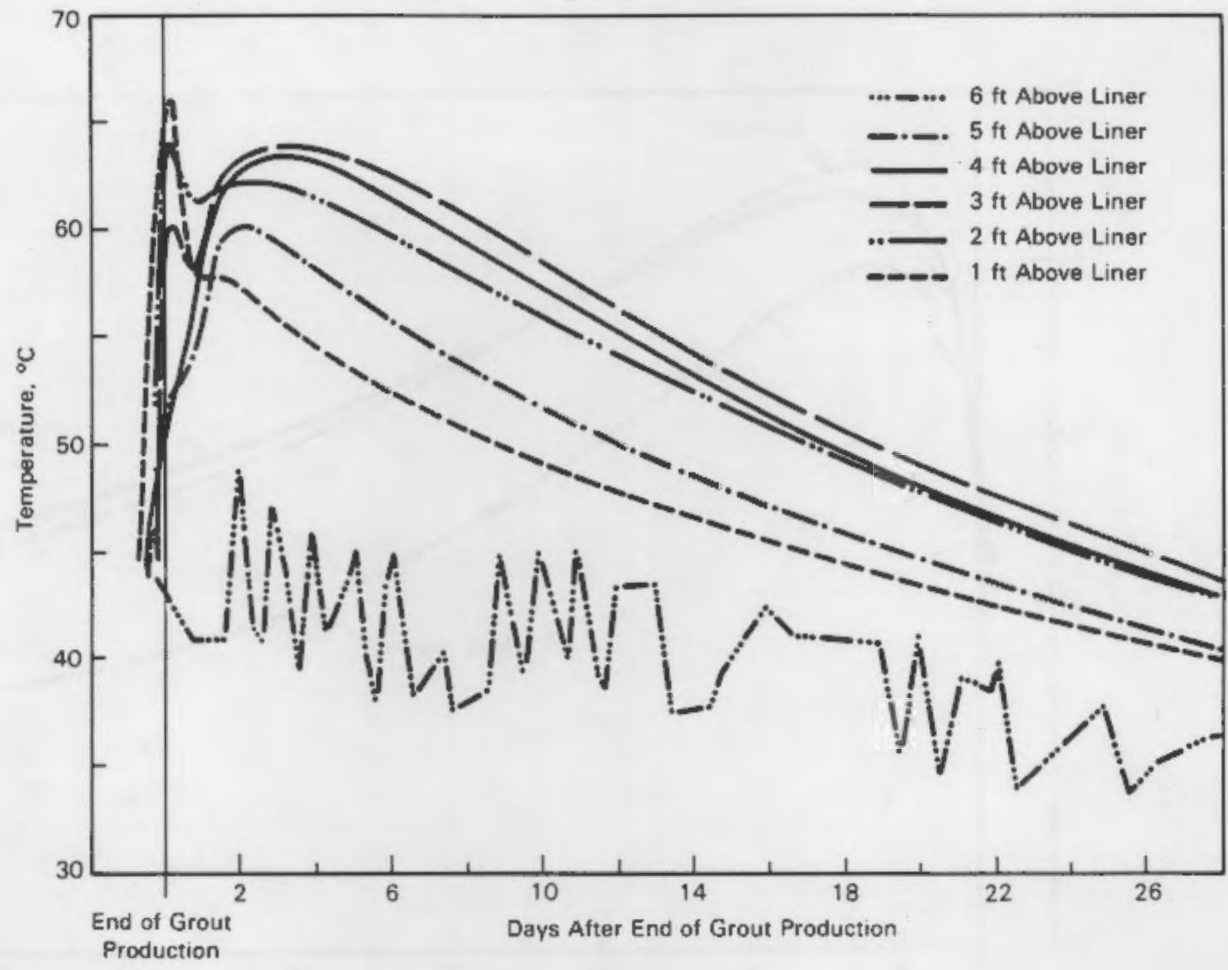

FIGURE 4.7. Temperature Profile - $17 \mathrm{ft}$ From Discharge Nozzle

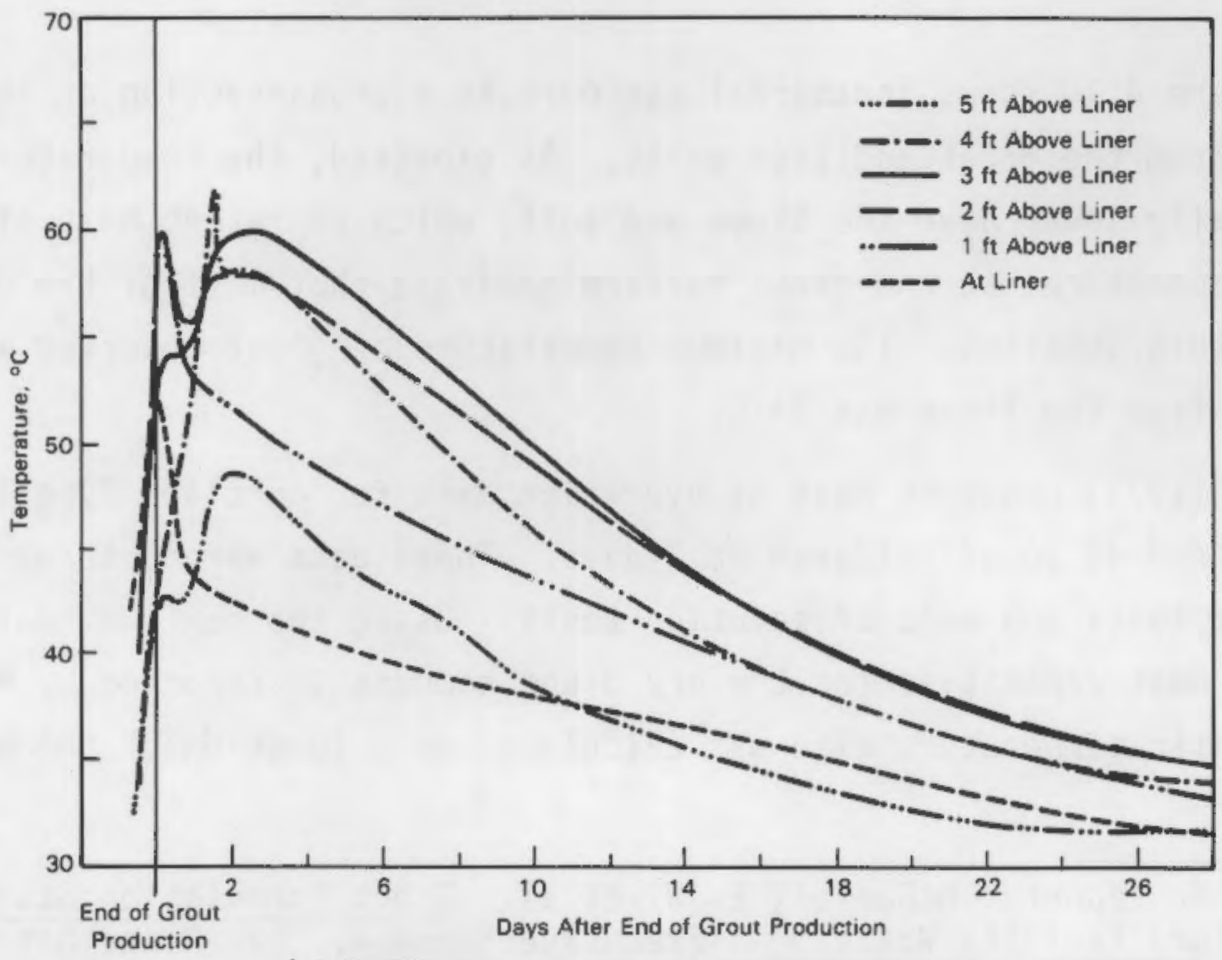

FIGURE 4.8. Temperature Profile - $40 \mathrm{ft}$ From Discharge Nozzle 


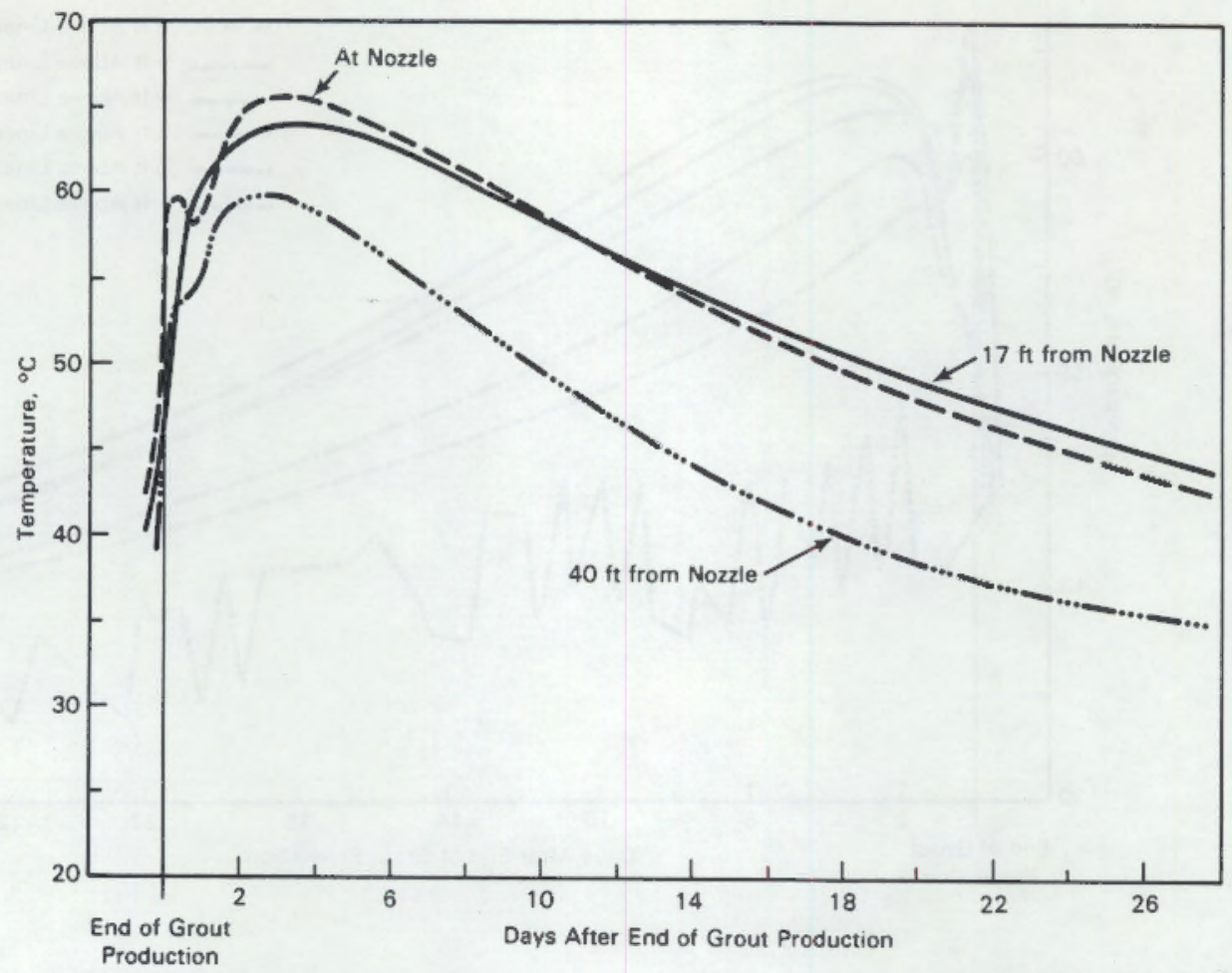

FIGURE 4.9. Temperature $3 \mathrm{ft}$ From Trench Floor at Three Trench Locations

Figure 4.10 shows isothermal contours in a cross-section of the trench 17 feet from the grout addition point. As expected, the temperature is dramatically lower near the liner and soil, which represent heat sinks. The lower temperatures at the grout surface indicate that most of the grout heat is lost at this location. The maximum temperature of grout observed within 2 inches from the liner was $54^{\circ} \mathrm{C}$.

Lea (1971) presents heat of hydration data for portland Type II cement ranging from 46 to $61 \mathrm{cal} / \mathrm{gram}$ at 7 days. These data were determined through adiabatic tests and heat of solution tests. Using the maximum heat of hydration and heat capacities for the dry blend components reported by McDaniel, (a) an adiabatic temperature rise was calculated as a function of the water content

(a) Letter Report: McDaniel, E. W. et al. Grout Formulation Studies with Hanford Facility Waste: An Executive Summary. Oak Ridge National Laboratory, Oak Ridge, Tennessee (September 1984). 


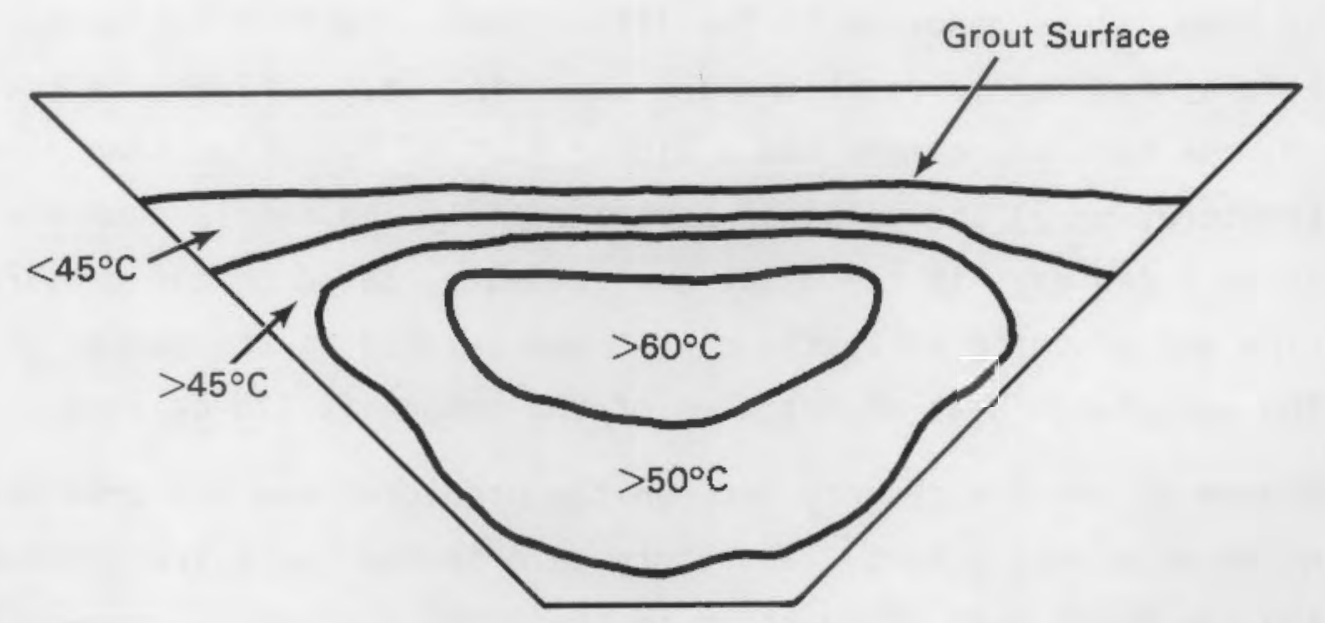

FIGURE 4.10. Isotherms in Pilot-Scale Trench Two Days After Production

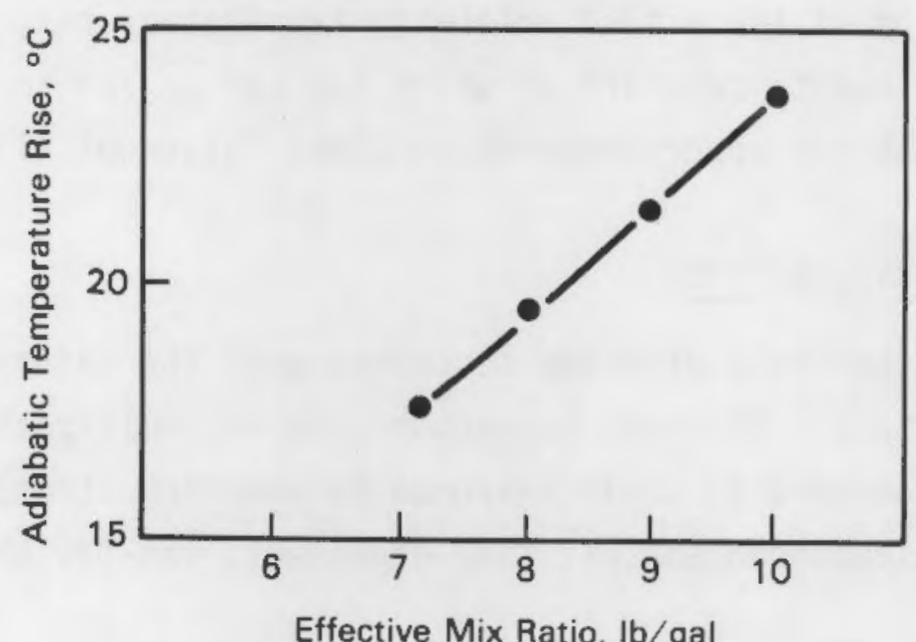

Effective Mix Ratio, lb/gal

FIGURE 4.11. Theoretical Adiabatic Temperature Rise in Simulated PSW Grout as a Function of Mix Ratio (heat of hydration $=61 \mathrm{cal} / \mathrm{g}$ cement)

in the grout (Figure 4.11). As shown, the maximum temperature rise of $37^{\circ} \mathrm{C}$ measured in the pilot-scale test is considerably greater than the calculated rise at a mix ratio of 7.2 pounds of dry blend per gallon of waste. Even the temperature rise at the low end of the trench $\left(31^{\circ} \mathrm{C}\right)$ exceeds the predicted temperature rise of $16^{\circ} \mathrm{C}$. The difference in water content of the grout as a function of the position in the trench therefore does not explain the higherthan-expected temperature rise. It appears that more energy is released than 
expected from values reported in the literature. Possible explanations are:

1) additional exothermic reactions are occurring (e.g., flyash is reacting with lime), 2) the portland cement has a higher heat of hydration than reported in the literature, or 3 ) the portland cement rapidly and nearly completely hydrates in a few days in the grout environment. Based on the measured temperature rise and assuming adiabatic conditions existed in the center of the monolith, the calculated heat of reaction of the cement is $126 \mathrm{cal} / \mathrm{gram}$.

Because of the discrepancy between the predicted and measured temperature rise in the pilot-scale test, laboratory calorimeter tests are recommended to establish the total heat of reaction in the grout mixture. Large-scale adiabatic tests are also suggested to positively establish maximum temperature rise and to provide data that can be compared with the laboratory test data.

Identification of the actual adiabatic temperature rise is required to determine the maximum temperature at which PSW can be fed to the grout process while ensuring that the upper temperature limit for grout will not be exceeded.

\subsection{RHEOLOGICAL EVALUATIONS}

Rheology is the field of study concerned with the deformation and flow behavior of materials. Viscous, pseudohomogeneous, multiphase fluid mixtures are classified according to their response to shearing stresses. PSW grout is classified as a pseudohomogeneous, time-dependent, non-Newtonian fluid (Lokken et al. 1986).

Prior to each test of the pilot-scale grout process, rheological and physical evaluations are performed on grout prepared in the laboratory using the simulated liquid waste and dry blend prepared for the test. These evaluations are used to determine the mix ratio to be used during the test that results in grout which meets established physical and rheological criteria. Lokken(a) has

(a) Letter Report: Lokken, R. 0., P. F. C. Martin, M. A. Reimus, and C. J. Mann. 1986. Adequacy of Attapulgite Clays for Use in Hanford Facilities Waste Grouts. Pacific Northwest Laboratory, Richland, Washington. 
shown that variability in attapulgite clay properties and in the blending process, for example, significantly affect grout slurry properties, and in turn, the mix ratio.

During each test of the pilot-scale process, rheological evaluations are performed to verify that the grout is in the turbulent flow regime throughout the entire transfer line. In addition, rheological evaluations are performed on grout from the process to determine if they are comparable to grouts produced in the laboratory.

In this section of this report, the method used to determine the mix ratio for the pilot-scale test is presented, as well as the results of rheological evaluations performed prior to and during the pilot-scale test. In addition, predictions of pressure drop in the piping are compared with actual data from the pilot-scale test.

\subsubsection{Mix Ratio Determination}

The mix ratio (pounds of dry blend per gallon of waste) to be used in a test of the pilot-scale process is based on physical and rheological evaluations of laboratory-produced grouts mixed at different mix ratios. The mix ratios used in a pilot-scale test typically vary from 7 to 8 pounds of dry blend per gallon of waste.

The optimum mix ratio is the one that yields grout with the lowest critical flow rate, the lowest 10-min gel strength, and the lowest amount of drainable liquid. Compressive strength measurements at 28 days are also performed on selected grouts to verify that the strength exceeds 50 psi. PSW grouts produced with the reference formulation have compressive strengths 6 to 12 times the acceptable value of 50 psi.

In this section, the methods for measuring the critical flow rate, 10-min gel strength, drainable liquid, and compressive strength of the grout are presented.

\subsubsection{Critical Flow Rate}

The critical flow rate is defined as the flow rate at which turbulent flow begins. Grout must be pumped at rates sufficiently high to assure turbulent 
flow at all locations within the pipe. Turbulent flow is required to prevent grout solids from depositing in the piping which could eventually cause plugging.

The critical flow rate is calculated using a critical Reynolds number of 2100, the power law model (Smith 1976), data from a Fann ${ }^{\circledR}$ viscometer, and the apuropriate process parameters. For the TGF, the design critical flow rate is less than $65 \mathrm{gpm}$. For the pilot-scale test, the critical flow rate was required to be less than the operating flow rate of $15 \mathrm{gpm}$.

The use of a critical Reynolds number $\left(R_{C}\right)$ of 2100 to calculate critical flow rate results in a nonconservative value for a non-Newtonian fluid such as grout. The use of $a \mathrm{Re}_{c}$ of 2100 is typically used for Newtonian fluids. The Metzner and Reed approach for pseudoplastic, non-Newtonian materials results in a critical Reynolds number of 2600 (Metzner and Reed 1955) for a typical PSW grout with the following properties:

$$
\begin{aligned}
\text { flow behavior index }(n) & =0.5 \\
\text { flow consistency index }(K) & =0.127 \mathrm{lbf} \mathrm{s} / \mathrm{ft}^{2} \\
\text { density } & =11.691 \mathrm{~b} / \mathrm{gal}
\end{aligned}
$$

The critical flow rates associated with $\mathrm{Re}_{\mathrm{C}}$ 's of 2100 and 2600 for a typical PSW grout in a 2-inch diameter pipe are $38 \mathrm{gpm}$ and $44 \mathrm{gpm}$, respectively. Because the grout thickens in the pipe (discussed in Section 4.3.3), more conservatism is warranted in choosing the critical Reynolds number. Hence, the Metzner and Reed approach, where $\mathrm{Re}_{c}$ is based on the flow behavior index, is preferred.

\subsubsection{Drainable Liquid}

The amount of drainable liquid is determined by first pouring grout into a 250-mL graduated cylinder. During the next few days, the grout settles and drainable liquid appears on top of the grout. The volumes of solid and liquid are monitored periodically for 28 days. After filling the disposal vault, liquid that does not reabsorb will be pumped from the vault, stored in a tank,

Fann Instrument Corporation, Houston, Texas. 
and eventually processed into grout. This process is costly, therefore, it is desirable that the amount of drainable liquid be minimized.

\subsubsection{Ten-Minute Gel Strength}

The 10-min gel strength can be used to determine the theoretical maximum pressure the pump must apply to the grout to reinitiate flow following a $10-m i n$ downtime. When the grout is allowed to sit stagnant in a pipe, the grout will gel. To reinitiate flow, the pump must exert a pressure equal to the product of the gel strength and pipe surface area. Note that the gel strength needs to be known as a function of time; 10-min gel strength is an arbitrary choice to characterize grout gel properties.

The 10-min gel strength is determined after viscometer measurements have been conducted. The grout sample is allowed to sit undisturbed for 10 minutes in the Fann viscometer sample cup. After 10 minutes, the rotational speed is set at $3 \mathrm{rpm}$ and the maximum dial deflection is read. The TGF specification for the 10-min gel strength is less than $1001 \mathrm{bf} / 100 \mathrm{ft}^{2}$. Typical gel strengths of PSW grout range from 15 to $251 \mathrm{bf} / 100 \mathrm{ft}^{2}$. A gel strength reading of $100 \mathrm{lbf} / 100 \mathrm{ft}^{2}$ corresponds to $100 \mathrm{lbf}$ in $141 \mathrm{linear}$ feet of 2 -in. pipe. Thus, for 1500 feet of pipe, a pump must be capable of generating 7851 bf to reinitiate grout of the specified gel strength.

\subsubsection{Compressive Strength}

The current specification for grout compressive strength is a minimum of 50 psi. The compressive strength at 28 days is determined by pouring a sample of grout in a 2-in. diameter cylinder 4 inches long. The sample is sealed and allowed to cure undisturbed for 28 days. Compressive strength tests are conducted on an Instron test machine in accordance with ASTM C-109 (ASTM 1985).

\subsubsection{Summary of Grout Performance Criteria}

In summary, acceptable mix ratios for PSW grouts are those that result in grouts that have critical flow rates of less than $65 \mathrm{gpm}$, minimal drainable liquids after 28 days, 10 -minute ge 1 strengths 1 ess than $1001 \mathrm{bf} / 100 \mathrm{ft}^{2}$, and compressive strengths greater than 50 psi at 28 days.

- Instron Corporation, Canton, Massachusetts. 
Low critical flow rates are desirable because they result in: 1) lower flow angles in the grout disposal system, 2) lower temperature rise, and 3) perhaps a lower potential for grout cracking. Potential disadvantages of low critical flowrates include: 1) more separated liquid, 2) slower cure rates, and 3 ) less strength.

Laboratory tests and previous grout production tests have shown that grouts produced at mix ratios that result in critical flow rates of approximately $37 \mathrm{gpm}$ (in TGF piping) possess the desired flow properties while still meeting the drainable liquid, 10-minute gel strength, and compressive strength criteria.

\subsubsection{Pilot-Scale Test Rheological Evaluations}

Rheological evaluations of grout produced prior to and during the pilotscale test were performed. The information gained from these evaluations and how the data were used during grout processing are presented in this section.

\subsubsection{Tests Performed Prior to the Pilat-Scale Test}

Prior to the pilot-scale test, laboratory tests were performed using the simulated PSW and dry blend prepared for the pilot-scale test to determine if a mix ratio of 7.5 pounds per gallon (the nominal mix ratio for the grout formulation) would result in a grout that would pass the critical flow rate criterion.

The critical flow rates of nine samples of grout produced in the laboratory averaged $10.4 \mathrm{gpm}$ with a standard deviation of $0.37 \mathrm{gpm}$. These data indicated that turbulent flow would be achieved during the pilot-scale test if the targeted flow rate of $15 \mathrm{gpm}$ was maintained. The grout was also expected to pass the drainable liquid and 10-minute gel strength criteria although these properties were not specifically evaluated due to the limited time available.

The critical flow rate calculated for grout produced in the laboratory prior to the pilot-scale test (mix ratio of 7.5 ) was lower than the critical flow rate for grout with the same mix ratio sampled from the pilot-scale process surge tank. The critical flow rates for the laboratory and process grouts were $10.4 \mathrm{gpm}$ and $13.1 \mathrm{gpm}$, respectively. 
Several factors affect the critical flow rate determined at a particular mix ratio. These factors include the amount of shear imparted by the mixing apparatus, the conditions at which the dry blend is stored, and the length of time it is stored. To negate the storage effects, rheological evaluations of laboratory grouts and process grouts need to be performed at the same time. Thus, laboratory mixing methods can be evaluated as to their effectiveness in duplicating the shear history imparted in the grout process.

At the TGF, it is planned to produce grout in the laboratory using actual waste samples and procedures that have been shown to be effective in duplicating the shear history of the process. Testing of such grouts will provide confidence that the predicted properties, such as critical flow rate, are valid for the expected processing conditions.

\subsubsection{Tests Performed During the Pilot-Scale Test}

During the pilot-scale test, critical flow rates for $1-i n$. sch 40 pipe (used in the pilot-scale test) were calculated based on grout properties at the surge tank and at the pipe discharge to the trench. The data were used to 1) indicate whether turbulent flow was maintained in the piping, 2) determine the effect of shear imparted by the flow of grout in the pipe, and 3) compare the properties of grout prepared in the laboratory to grout produced by the process equipment.

Figure 4.12 depicts the critical flow rates calculated throughout the test using the pilot-scale parameters. The mix ratio was adjusted twice during the pilot-scale test, once after the first 40 minutes when higher-than-desired critical flow rates at the discharge to the trench were measured, and once because changes were observed in the rheological properties of dry blend when a new trailer-load of the material was added to the process.

During the first 50 minutes of grout production, grout at the discharge into the trench was much thicker than at the surge tank. The shear imparted by pumping the grout through an equivalent length of 155 feet of pipe significantly thickened the grout.

The effects of shear thickening can be observed in the first time interval shown in Figure 4.12. The critical flow rate calculated at the surge tank was 


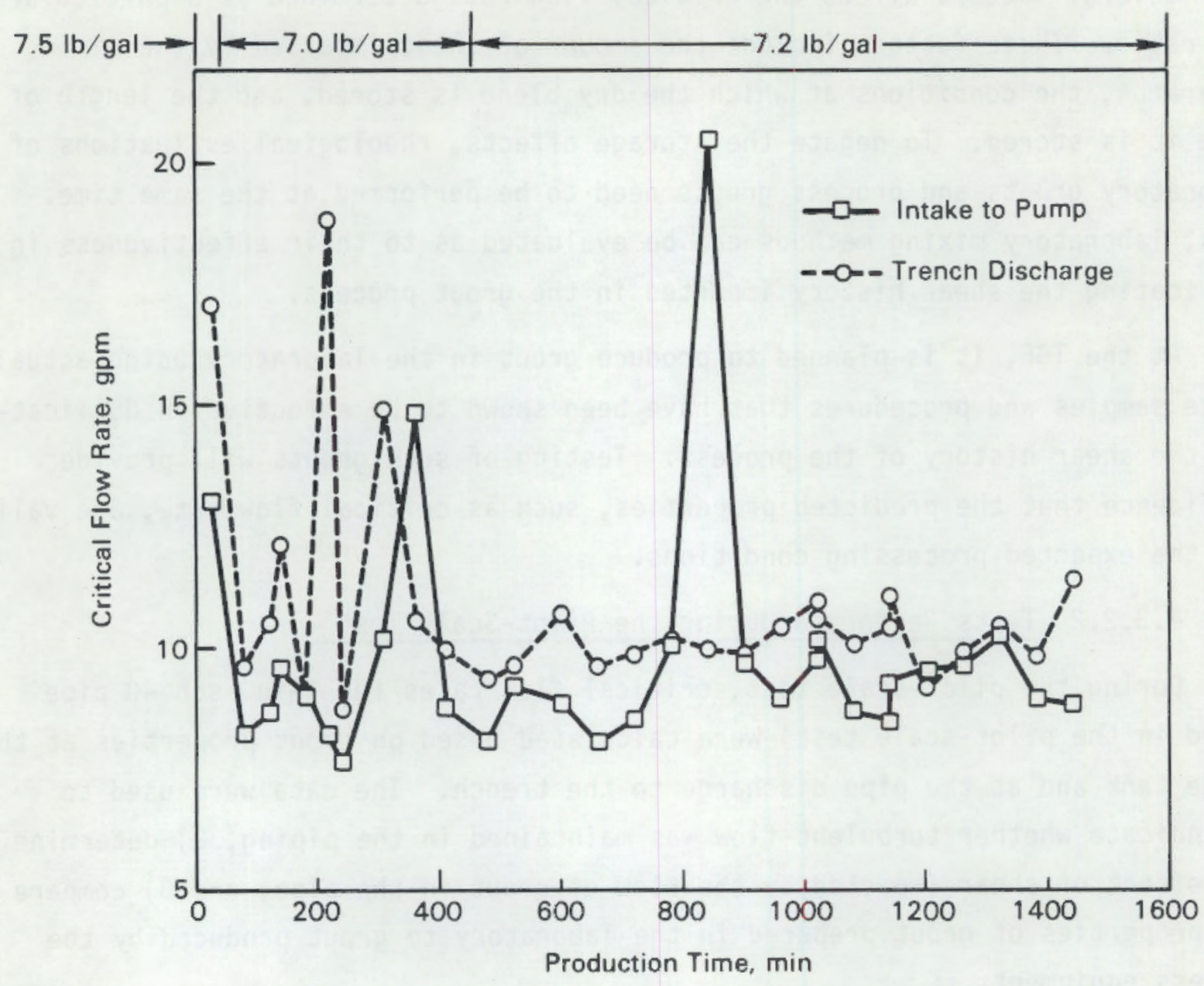

FIGURE 4.12. Pilot-Scale Test Critical Flow Rates at the Surge Tank and at the Discharge to the Trench

13.1 gpm whereas at the pipe discharge it was $17.1 \mathrm{gpm}$. Therefore, the mix ratio was decreased from the initial level of 7.5 to 7.0 pounds per gallon. Decreasing the mix ratio reduced the critical flow rate at the trench discharge to less than the operational flow rate of $15 \mathrm{gpm}$. Therefore, turbulent flow throughout the piping was assured.

The first dry-blend trailer change took place after approximately 400 minutes of grout production. Rheological data on grout produced with dry blend from the second trailer resulted in critical flow rates slightly less than 
those calculated with the grout produced with dry blend from the first trailer. Therefore, the mix ratio was increased from 7 pounds per gallon to 7.2 pounds per gallon.

The second and final dry blend trailer change took place after approximately 975 minutes of grout production. The critical flow rates calculated from the grout made from the dry biend in this trajler were not significantly different from the previous critical flow rates. Therefore, no change in mix ratio was made as a result of this trailer change.

\subsubsection{Shear Thickening Effects}

Phosphate/Sulfate $N$ Reactor Waste grout has been shown to be a pseudohomogeneous, non-Newtonian fluid sometimes exhibiting shear thickening properties (Lokken et a1. 1986). The rheological properties of grout flowing in a pipe are dependent on the amount of shear induced by the flow in the pipe and by the amount of time the grout is subjected to that shear. The shear induced during pumping is a function of the velocity of grout in the pipe and the pipe diameter. For a given velocity, the shear rate induced by the 1-in.-diameter pipe used in the pilot-scale test is approximately twice that induced by the 2-in.-diameter pipe planned for the TGF.

Shear thickening had not been observed in pump tests performed in 1985 except during one test in which the flow of grout was severely throttled through a nearly closed valve. In the 4000-gal test in May of 1986, shear thickening was observed by pumping grout through 71 feet of $3 / 4-i n$. pipe at $10 \mathrm{gpm}$. This was the first time dry blend from the DMRHF had been used in a test of the pilot-scale process. A difference in either the blending procedures and equipment used at the DMRHF and at PNL or the attapulgite properties is believed responsible for the observed shear thickening.

The effects of shear on the grout during pumping in the pilot-scale test can be evaluated from Figure 4.12 by noting the difference in the critical flow rates at the surge tank and at the pipe discharge. The average critical flow rate at the surge tank for the period when the mix ratio was $7.2 \mathrm{lb} / \mathrm{gal}$ was 
$9.25 \mathrm{gpm}$, whereas the average critical flow rate at the discharge to the trench was $10.24 \mathrm{gpm}$. Thus, the CFR increased approximately $11 \%$ in an equivalent length of pipe of 155 feet.

The TGF piping network is expected to cause less shear thickening per foot of pipe than experienced during the pilot-scale test (assuming identical grout properties at the pump discharge) because the shear rate will be about $340 \mathrm{~s}^{-1}$ versus $600 \mathrm{~s}^{-1}$ in the pilot-scale test. However, the TGF pipe network will be up to 20 times longer than the pipe network used in the pilot-scale test. The actual amount of shear thickening expected in the TGF can best be determined by pumping grout in a 2-in.-diameter pipe at the TGF flow rates over distances long enough to establish the effects of time at the appropriate shear rate. (This phenomenon will be examined in FY 1987.)

\subsubsection{Pressure Drop Predictions}

The pressure drops expected in the 155 equivalent feet of $1-i n$. pipe in the pilot-scale test were calculated using the Metzner and Reed model, as described in Fow, McCarthy and Thornton (1986), and the Smith model (Smith 1976) for non-Newtonian, pseudoplastic fluids. The results of the pressure drop calculations and the data observed during the pilot-scale test are summarized in Table 4.2. The calculations were based on an average flowrate of

TABLE 4.2. Comparison of the Calculated Pressure Drops and Observed Pressure Drops

\begin{tabular}{|c|c|c|c|c|c|}
\hline \multirow[t]{2}{*}{$\begin{array}{l}\text { Grout } \\
\text { Production } \\
\text { Time, min } \\
\end{array}$} & \multicolumn{2}{|c|}{$\begin{array}{c}\text { Calculated Pressure } \\
\text { Drop-Surge Tank, } \\
\text { psi }\end{array}$} & \multicolumn{2}{|c|}{$\begin{array}{c}\text { Calculated Pressure } \\
\text { Drop-Pipe }\end{array}$} & \multirow[t]{2}{*}{$\begin{array}{l}\text { Observed } \\
\text { Pressure } \\
\text { Drop, psi }\end{array}$} \\
\hline & $M-R^{(a)}$ & Smith (b) & $M-R$ & Smith & \\
\hline 523 & 10.1 & 6.3 & 9.5 & 6.4 & 14.8 \\
\hline 660 & 10.4 & 5.9 & 9.3 & 6.4 & 13.7 \\
\hline 785 & 11.4 & 6.9 & 8.9 & 6.5 & 14.7 \\
\hline 900 & 10.8 & 6.3 & 9.3 & 6.4 & 14.8 \\
\hline 1254 & 11.1 & 6.4 & 9.3 & 6.4 & 14.7 \\
\hline
\end{tabular}

(a) Metzner and Reed model (Fow, McCarthy and Thornton 1986). (b) Smith model (Smith 1976). 
$15.3 \mathrm{gpm}$, an equivalent length of pipe of 155 feet, and a difference in elevation between the pump and pipe discharge of 149 inches.

The pressure drops reported in the second and third columns in Table 4.2 are based on the assumption that the grout rheological properties in the pipe did not change from those determined at the surge tank. In the fourth and fifth columns, the assumption that grout properties did not change from those determined at the piping discharge was used to calculate pressure drops. Theoretically, the pressure drop data measured during the pilot-scale test (Column 6) should lie somewhere between the predicted pressure drops in Columns 2 and 4 or 3 and 5 .

In all cases, the pressure drops predicted by the Smith and the Metzner and Reed model were lower than those observed during the pilot-scale test. The Metzner and Reed model predicted 35\% lower pressure drops whereas the Simith model predicted 55\% lower pressure drops. For example, at 900 minutes of grout production, the pressure gauge at the pump discharge read 14.8 psi. The Metzner and Reed model using viscometer data generated with grout from the surge tank and from the pipe discharge into the trench predicted pressure drops of 10.8 and 9.3 , respectively. The Smith model using the same viscometer data predicted pressure drops of 6.3 and 6.4 , respectively.

The Smith model uses one curve for all non-Newtonian fluids to determine the friction factor at a given Reynolds number. In contrast, the friction factor from the Metzner and Reed model is dependent on the Reynolds number and the flow behavior index, $n$. The flow behavior index for the grouts reported in Table 4.2 ranges between 0.51 and 0.65 . In addition, pipe roughness was taken into account in the calculated pressure drop using the Metzner-Reed model.

The Metzner and Reed model is recommended for predicting pressure drops for non-Newtonian, pseudoplastic fluids. However, viscometer data from the laboratory suggested that grout is actually a yield-pseudoplastic, (a) nonNewtonian fluid. In subsequent tests, more accurate rheological data can be obtained by using a Haake rotational viscometer or the Fann viscometer operated

(a) An explanation and discussion of yield-pseudoplastic fluids is found in Fow, McCarthy and Thornton (1986). 
at very low rpm's to determine a yield strength of the grout. Then, it is possible that more accurate pressure drops could be predicted.

\subsection{FLUSHING}

If grout stagnates in the pipe network or in the process equipment such as the mixer, pump, and surge tank, it will gel and eventually harden. The presence of hardened grout causes various problems, depending on the affected piece of equipment. To prevent the formation of hardened grout, routine flushes should be performed to remove grout accumulations from the equipment. In addition, flushes must also be performed when the processing equipment is shut down for more than a specified interval. (Twenty minutes was the interval specified for the pilot-scale equipment.) Because water is needed for flushing, but excess water is undesirable in the vault because it must eventually be removed, a compromise must be reached when designing the flush system and flushing procedures.

This section describes the flush systems for the pilot-scale mixer, pump, surge tank, and piping. Results of their effectiveness are presented. The improvements that were made to the pilot-scale equipment before the test to prevent accumulations of grout are discussed, as well as recommendations for further improvements.

\subsubsection{Mixer}

This section describes modifications made to the grout mixer to retrofit a flush system. The performance of the flush system is discussed, and recommendations are given for the flush system for the TGE mixer.

\subsubsection{Modifications to Equipment}

In previous tests, it was found that grout hardened in a $1 / 8-i n$. thick layer at the dry blend inlet of the pilot-scale mixer if the mixer was not flushed (Figure 4.13). Plugging of the mixer inlet could occur if the grout were allowed to accumulate during longer production periods. The pilot-scale mixer was subsequently modified with a spray nozzle in the dry blend inlet to spray a thin, cone-shaped spray of water down into the mixer. 


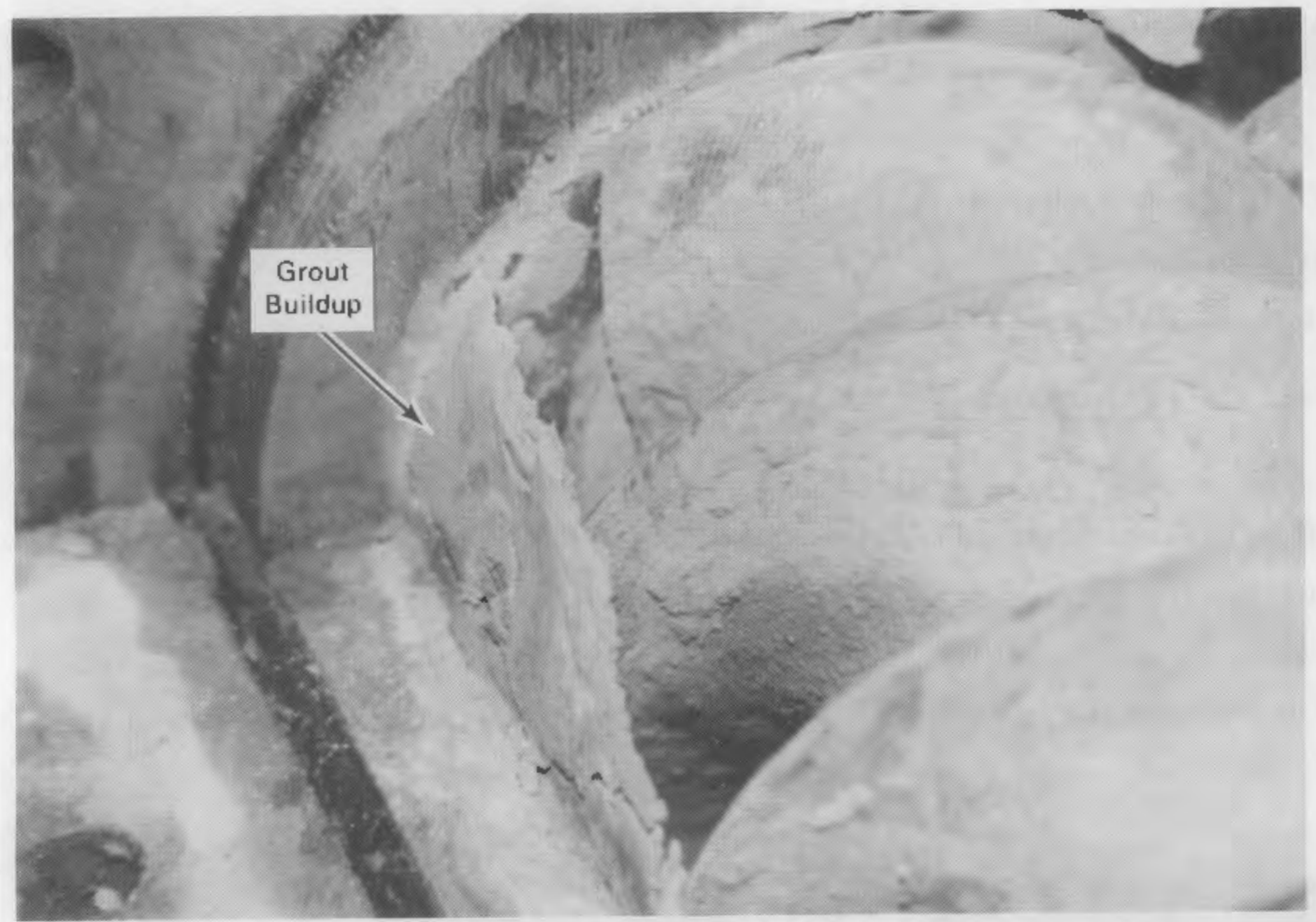

FIGURE 4.13. Grout Buildup at the Dry Blend Inlet Port Prior to Installation of Flushing System

\subsubsection{Flushing Requirements}

The procedure for flushing the inlet of the pilot-scale mixer specifies flushing with water for 7 minutes at $1.5 \mathrm{gpm}$ while the mixer is operating at $250 \mathrm{rpm}$. This procedure results in flushing the mixer with about 3.3 mixer volumes of water.

In the 4000-yal test performed in May of 1986, a single routine flush after 5 hours of grout production left an accumulation of about 0.1 inch of grout on the mixing blades. This accumulation was considered acceptable. In an effort to determine the maximum length of time allowable between flushes, routine flushes for the pilot-scale test were specified during the first trailer change (after about 10 hours of grout production) and every 12 grout production hours thereafter. 
During the pilot-scale test, frequent downtimes necessitated flushing; therefore, routine flushes were not performed as scheduled. Instead, 10 flushes were performed after the system had been down for more than 20 minutes at a time. In seven of those flushes, flush water was discharged into a drum instead of the trench. This resulted in approximately 31 gallons of flush water discharged to the trench from flushing the mixer (approximately 80 gallons of water was flushed into drums).

\subsubsection{Performance}

Figure 4.14 shows the pilot-scale mixer before the test; Figures 4.15 and 4.16 show the mixer after the test. After the test, the mixer blades were coated with hard grout up to $1 / 8-i n$. thick. The dry blend inlet port was also coated with an accumulation of wetted dry blend and grout up to 1/2-in. thick. Consequently, the mixer flush system was determined not adequate.

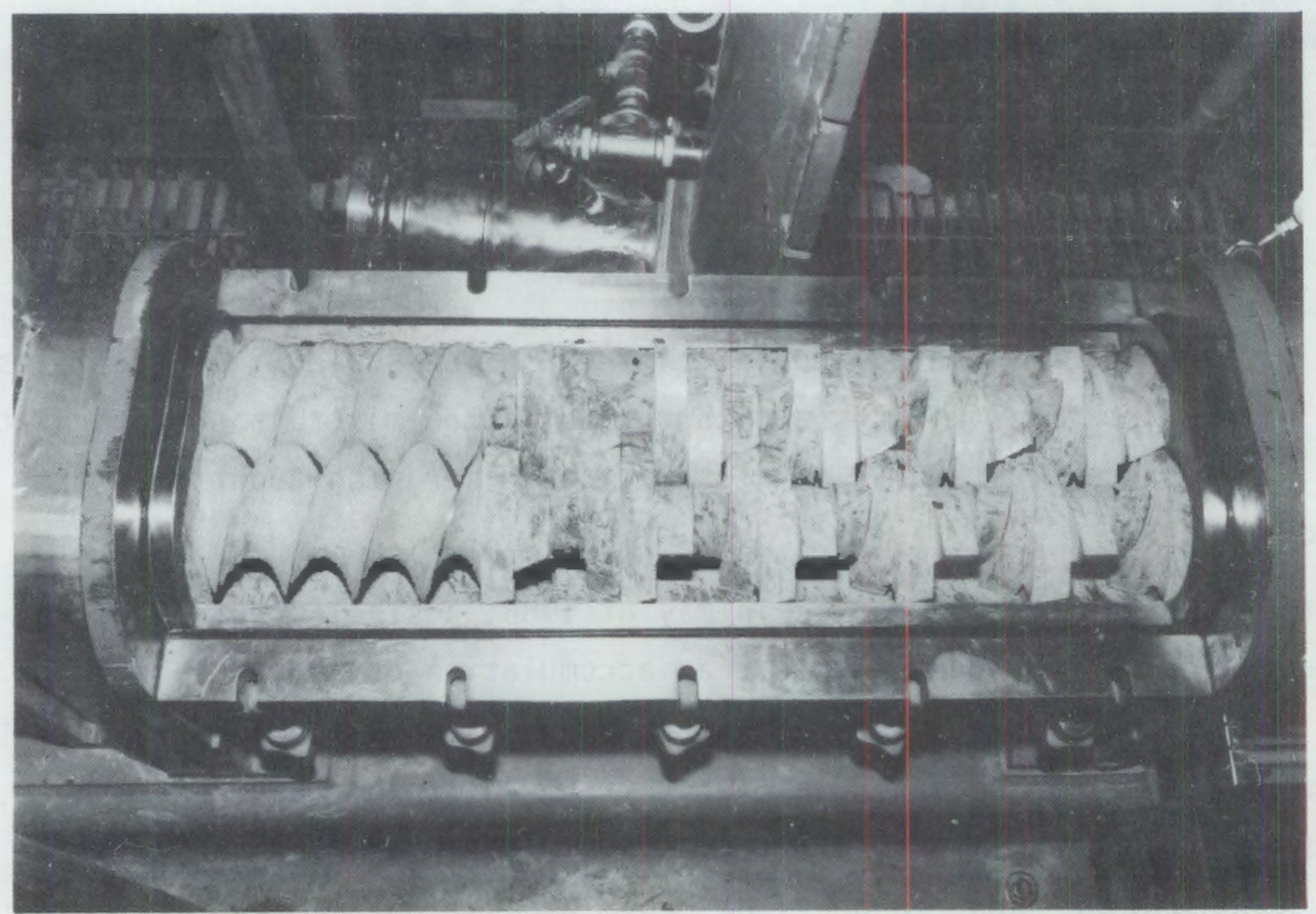

FIGURE 4.14. Pilot-Scale Mixer Before the Pilot-Scale Test 


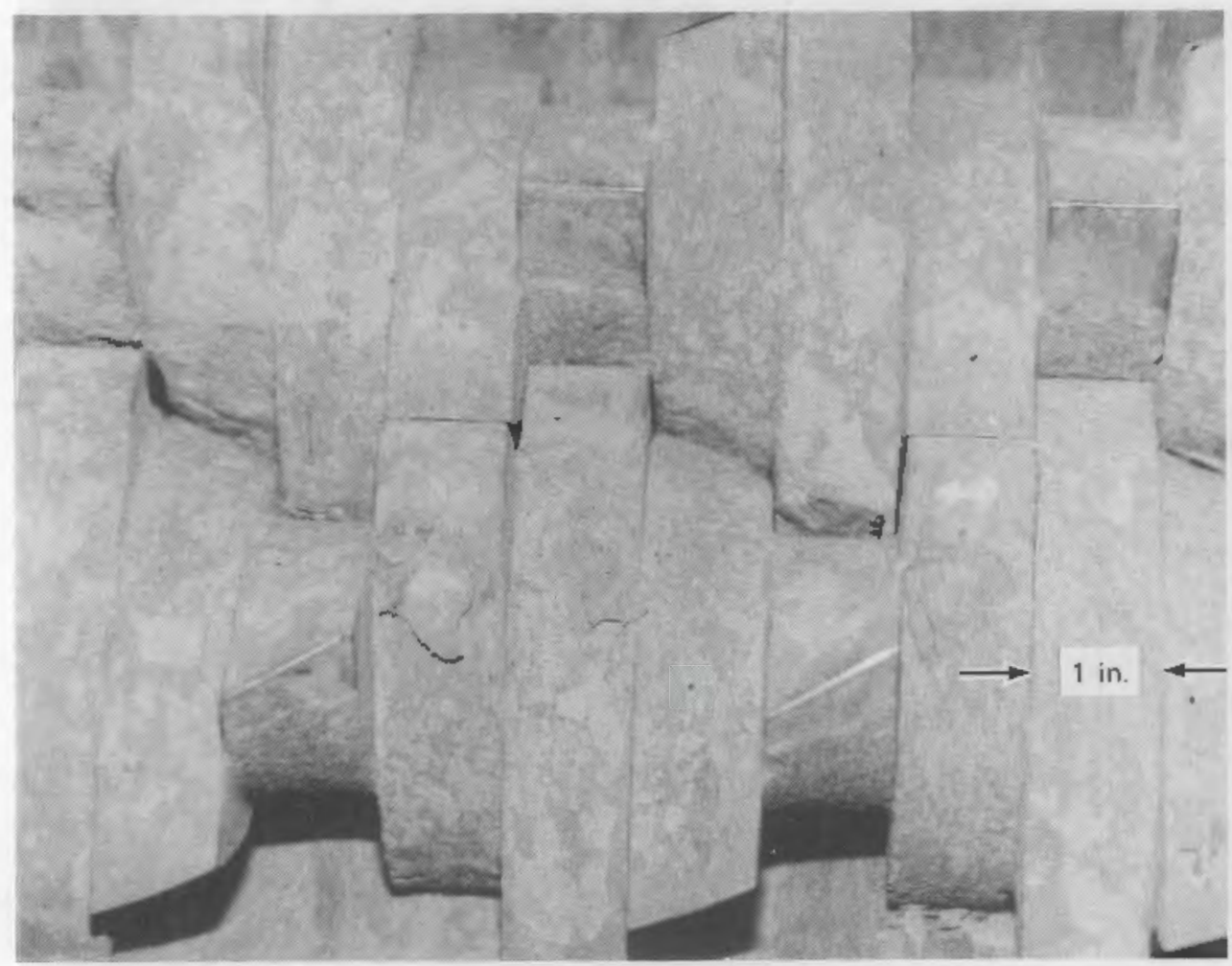

FIGURE 4.15. Pilot-Scale Mixer After the Pilot-Scale Test

The buildup of grout on the mixer blades was probably caused by an inadequate number of flushes. The yrout accumulated and hardened in the clearance spaces between the blades and the mixer cover (see figure 4.15). Some wear of the blades was observed near the dry blend inlet port. This wear is discussed in more detail in Section 4.5.3.3.) The amount of grout buildup on the blades was limited because of the self-cleaning characteristics of the mixer blade design. More frequent flushing might have removed the grout before it had a chance to harden, which may have prevented some of the wear on the blades. The use of abrasion-resistant tips on the blades of the TGE mixer should also minimize wear.

The buildup of grout on the blades of the TGE mixer is not expected to be a major problem. Hard buildups on the blades may become dislodged, but the mixing action should reduce this dislodged buildup such that it can be pumped without causing damage. 


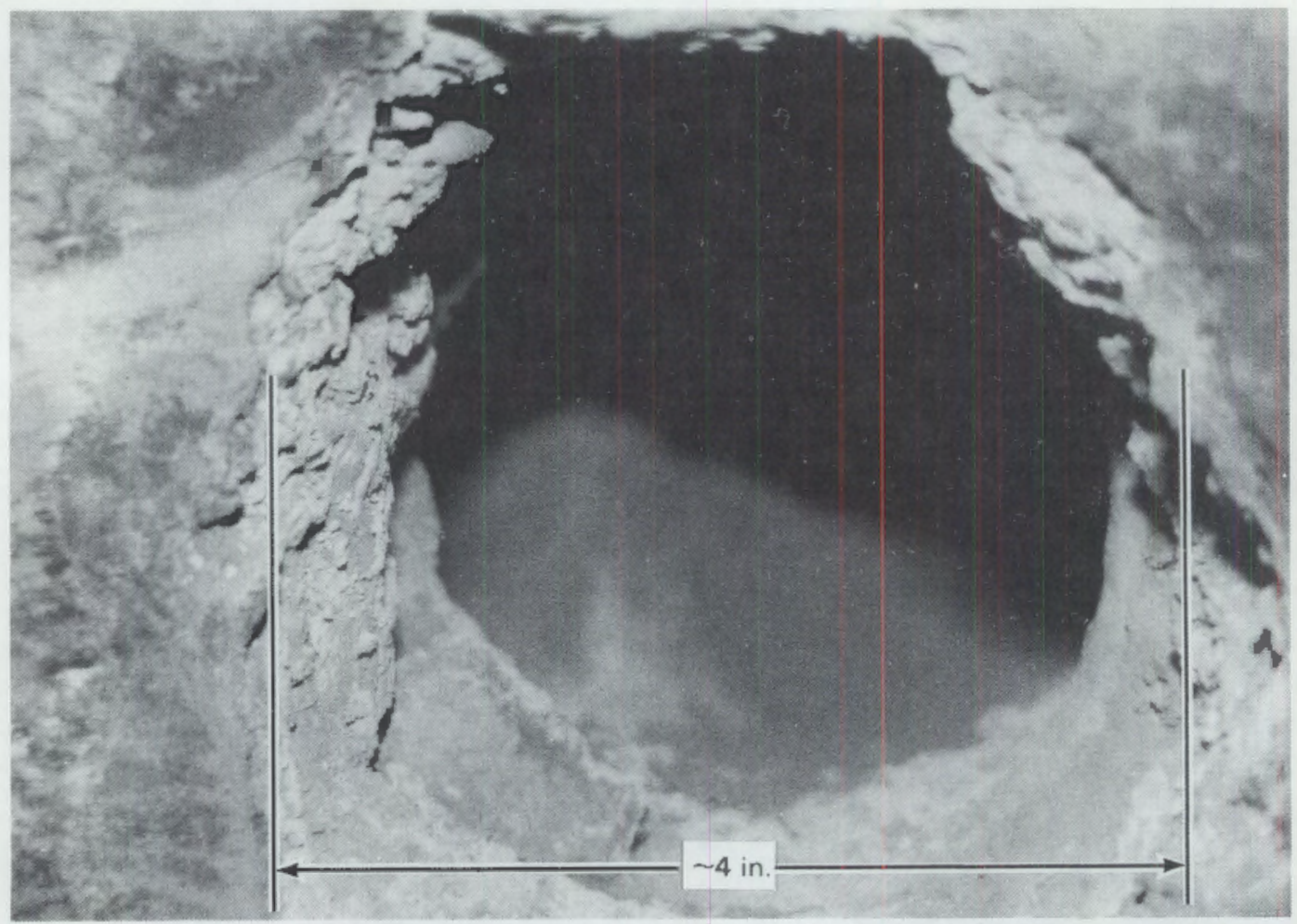

FIGURE 4.16. Dry Blend Inlet Port in Mixer Cover After the Pilot-Scale Test

The buildup of material in the mixer inlet is a more serious problem, however. Although the nozzle design for the flush system was effective in removing accumulations across the dry blend inlet port, it actually created a worse condition. Water from the nozzle contacted the screw section and was splashed up into the dry blend inlet port. During the pilot-scale test, the port was not allowed to dry before dry blend feeding was resumed. Consequently, the wet walls of the inlet port became coated with a layer of dry blend that hardened with time (Figure 4.16).

If the TGE mixer uses a flush system similar to that desiyned for the pilot-scale mixer, the dry blend inlet port should either be allowed to dry after flushing, or the inlet section should be constructed of a material that is not easily wetted.

\subsubsection{Surye Tank}

The surge tank was flushed manually with a hose. Water was delivered at flow rates between 5 and $8 \mathrm{gpm}$, using the least amount of water required to 
clean the sides and bottom of the tank. The surge tank was flushed twice during the test. Flushing the surge tank contributed a total of about 20 gallons of water to the trench.

Though the TGE and pilot-scale surge tanks have similar residence times, the pilot-scale tank had areas where grout was stagnant. The surge tank for the TGE will be very different from the pilot-scale surge tank (see Section 3.5.4). If the tank is agitated as planned, grout solids should not settle out as they did in the pilot-scale surge tank. The TGE surge tank, as planned, will have a shorter residence time and have greater sloping sides $\left(70^{\circ}\right.$ from the horizontal). The steeply sloped sides of the TGE surge tank also minimize the potential for grout to settle out on the sides and harden.

TGE designers must use care in sizing the tank agitator. The agitator must be effective in agitating the entire contents of the tank, but it must not impart so much shear that the grout thickens to the point that it cannot be pumped in turbulent flow. (The shear-thickening phenomenon is discussed in more detail in Section 4.3.3.)

\subsubsection{Pump}

In this section, the modifications made to the pilot-scale grout pump to retrofit a flush system are presented. Also discussed are the flush requirements, the performance of the flush system, and recommendations for the flush system for the TGE grout pump.

\subsubsection{Modifications to Equipment}

In previous tests, a layer of hardened grout was found at the base of the inlet housing of the pilot-scale pump (see Figure 4.17). If the housing grout buildup were allowed to grow, as would be expected during a TGF campaign, the pump inlet could become plugged or large particles could break free and damage the pump. The pilot-scale pump flush system was designed to periodically flush out accumulations that may develop at the base of the inlet section.

The flush system included a flat-jet spray nozzle installed into the side of the pump inlet (see Figure 4.17). The flush water to the nozzle was controlled with a normally closed solenoid value that was automatically activated 


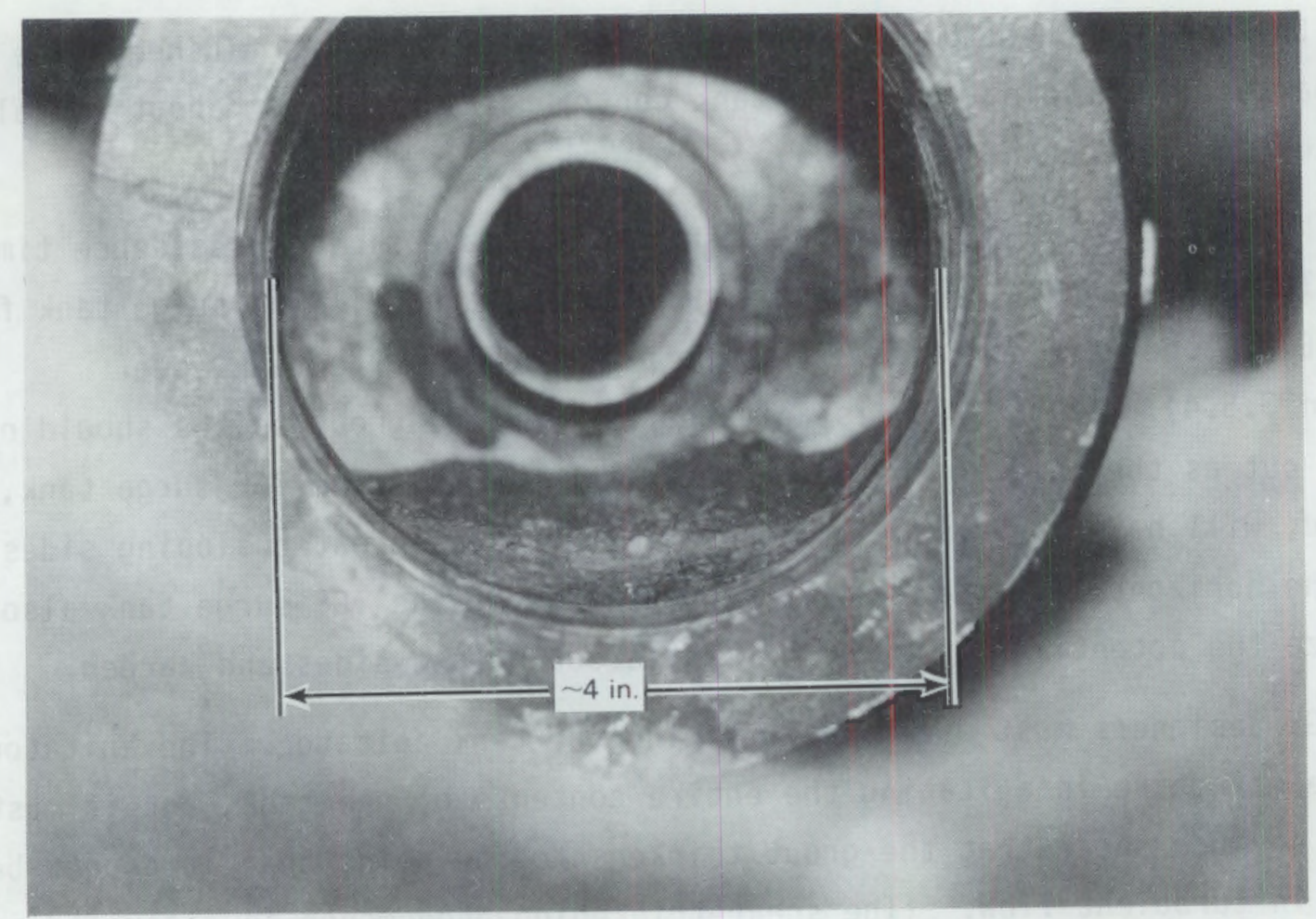

FIGURE 4.17. Cured Grout in Pump Inlet Without Flush System (Looking into pump inlet from discharge end)

for 3 seconds every 15 minutes. A total of $890 \mathrm{~mL}$ of flush water was delivered during each flush, corresponding to about 23 gallons of water used during the 24-hr test.

\subsubsection{Performance}

Twelve hours after grout production ended, the piping to the pump inlet was removed. No hardened grout had formed on the base of the pump inlet. A few small chunks or "flakes" of cured grout were observed, however. These particles are believed to have fallen from the wall of the surge tank during the final flush at the end of grout production. It was apparent that the pump inlet flush system performed very well. A similar flush system is recommended for the TGE pump. However, the interval between the automatic flushes could probably be increased from 15 minutes to 30 minutes. The decrease in the frequency of the flushes would decrease the amount of flush water pumped to the 
vaults. During a 1.4 million-gallon grout campaign, the pump inlet flush system operating at 30 -min intervals would contribute about 200 gallons of flush water.

\subsubsection{Piping}

To minimize the potential for grout accumulations in the piping, the piping to the vault should be designed to minimize the number of dead spots and sharp corners. Dead spots fill with settled grout solids, and, if not flushed clean, can eventually plug the line. To minimize the number of dead spots and erosion in the pipe, long radius elbows should be used whereever possible.

In this section, the flushing requirements for the pilot-scale piping are presented. Also discussed are the performance of the flushes as well as suggested flushing requirements for the TGF.

\subsubsection{Flushing Requirements}

The pilot-scale piping was flushed using the water from flushing the mixer and the surge tank. The water from flushing the mixer was discharged into the surge tank. When the mixer flush was completed, the collected flush was pumped through the piping at a flow rate of about $11.5 \mathrm{gpm}$ and at a Reynolds number of 35,000 . Turbulent flow, which occurs at Reynolds numbers greater than about 2100 for flush water, is desirable to take advantage of the scrubbing effect. This procedure was repeated after the surge tank was flushed clean.

In the event the grout pump failed and could not be used for flushing the piping, the pump could be valved off at its discharge end. In such a case, water from a high-pressure pump was available to flush the discharge piping via a plug valve located near the pump discharge.

The pilot-scale test plan specified performing a routine flush after 10 hours of grout production, and then 12 grout production hours later. Because of process upsets during the test, the piping was flushed using the described procedure after four hours of grout production and not again until at the end of the run, 20 grout production hours later. In real time, this translates to the first flush being performed after 10 hours and the final flush 25 hours later. 


\subsubsection{Piping Performance}

The amount of water flushed through the piping during each routine flush was equivalent to about 4.0 pipe volumes of water. Twelve hours after termination of grout production, the piping was disassembled and inspected for cleanliness. The first 125 feet of the piping looked very clean. A filmy buildup of grout (about 1/32-in.) had accumulated along the inside walls of the pipe. This buildup is not expected to be a problem because it will be scoured away the next time grout is pumped through the line.

The last 25 feet of pipe did contain accumulated grout. One horizontal section contained a buildup of soft grout that filled half the pipe (Figure 4.18$)$. The fact that the grout in the pipe had not hardened after 12 hours suggests that the grout did not steadily accumulate in the pipe but instead was deposited near the end of the test. Records show that the pump speed was decreased near the end of the final flush as the water level in the surge tank was lowered to prevent running the pump dry. This action may have allowed solids to settle out of a solids-rich slug of flush water.

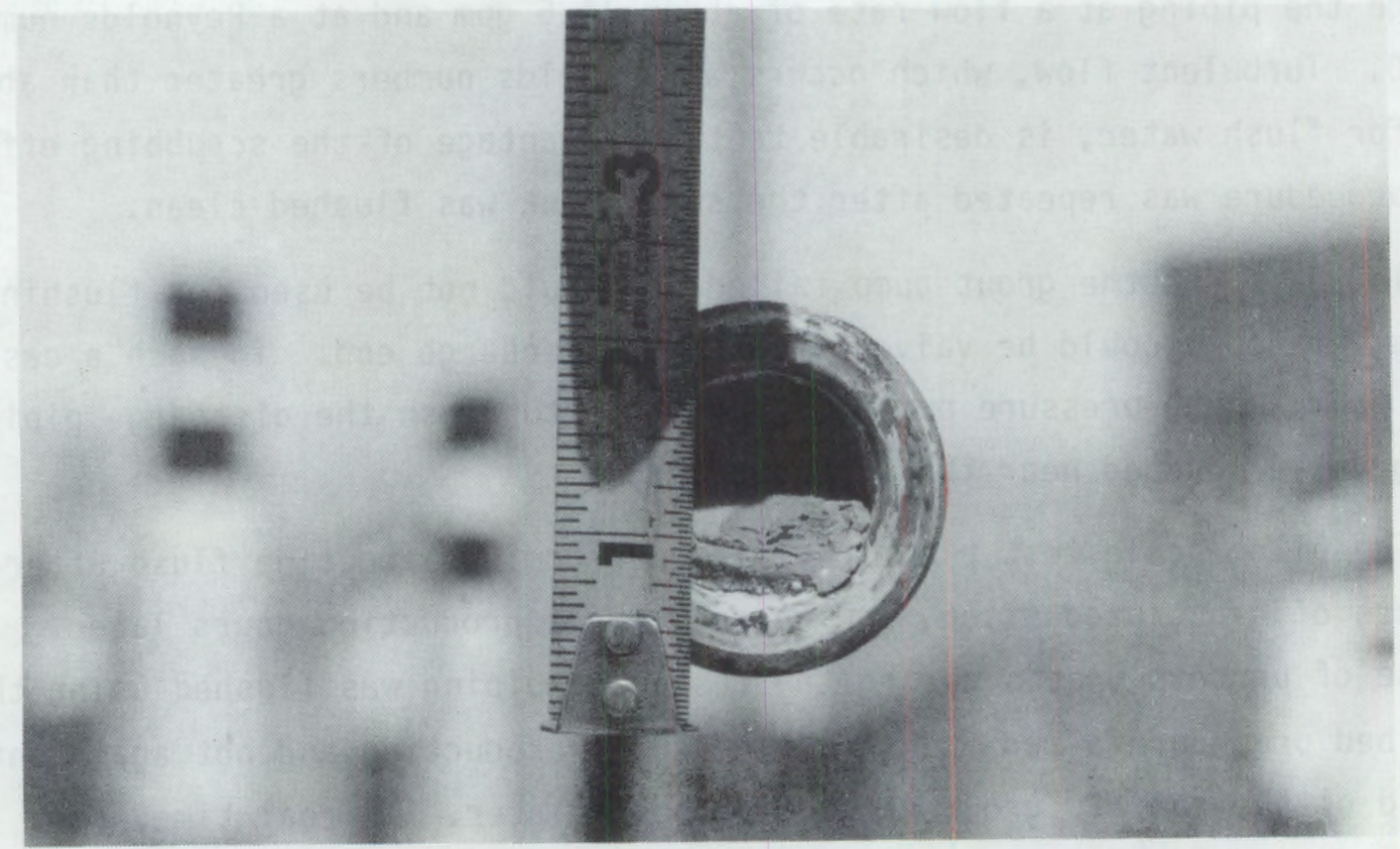

FIGURE 4.18. Grout Buildup in a Section of Pilot-Scale Pipiny 
The final flush water clearly contained a significant amount of solids due to the flushing of solids that had settled in the bottom of the surge tank. The excess buildup of solids in the run of pipe in Figure 4.18 may have been avoided if "clean" water had been flushed through the pipe following the final flush. To minimize the flush water added to the trench, this was not done. Another possible explanation for the solids in the last 25 feet of pipe is that this section of the pipe may have contained grout that was not in turbulent flow at all times. This condition may have resulted from the shear-thickening phenomenon previously discussed.

The TGE surge tank is not expected to accumulate grout solids as occurred in the pilot-scale surge tank. Cleaner flush water would result if no solids accumulated. If an adequate volume of relatively clean water is flushed through the piping at the end of processing, the amount of residual solids in the piping to the vault after flushing should be acceptable.

\subsubsection{Conclusions}

The results from the pilot-scale test suggest that the flushing system for the pilot-scale mixer is inadequate. Consequently, recommendations cannot be made at this time for the flush system for the TGE mixer. The pilot-scale pump inlet flush system is satisfactory for application to the TGE pump although the interval between flushes could be increased to 30 minutes. The piping to the vault should be flushed with relatively clean water at a Reynolds number greater than 10,000. At least three pipe volumes of "clean" water should be used.

\subsection{EQUIPMENT PERFORMANCE}

One of the primary objectives of the pilot-scale test was to evaluate the performance of the pilot-scale grout processing equipment during an extended period of operation. Information on equipment performance can be used in the design of the TGF and in the preparation of TGF operating procedures. 
In this section, the performance of the pilot-scale grout processing equipment used during the pilot-scale test is presented. Recommendations for improvements to the pilot-scale equipment and/or the TGF equipment are also discussed.

\subsubsection{Dry Blend Transfer and Feed System}

The dry blend transfer and feed system includes the supply trailer, the transfer system, the storage bin/baghouse, and the active bin/feeder (see Chapter 2.0 for details of the equipment).

Several problems were experienced with the dry blend transfer and feed equipment during the pilot-scale test. Occasionally, the dry blend would uncontrollably flood through the feeder, causing major process upsets. In addition, the high-level indicator and the vibrator in the storage bin intermittently failed to operate.

\subsubsection{Flooding}

Dry blend flooding caused major process upsets during the pilot-scale test. The first flood of dry blend occurred at the start of the test. Before the test began, the storage and active bin were emptied of dry blend that had been used in previous tests. To start the pilot-scale test, the storage bin was filled with fresh dry blend and then the active bin was filled. During the filling of the active bin, dry blend rushed through the feeder and out both the mixer discharge port and the oversize material port onto the vibrating screen. The fill valve between the storage and active bins was quickly closed, but not before approximately 20 cubic feet of blend had flooded through the system. This flooding incident was due to the flow of aerated and highly fluid dry blend through the feed pipe of the empty feed bin. The auger in the feed pipe did not provide a positive seal to prevent the discharge of fluidized dry blend.

During the test, significant flooding occurred ten times. Flooding would have occurred more often except that the operators learned to decrease the feed rate for a few seconds when thick grout was observed entering the surge tank. Flooding always occurred just after the end of a reload of the active bin. 
Flooding of dry blend during the test was probably due to a vacuum leak around the butterfly valve located at the base of the storage bin. When the contents of the active bin are emptied to a preset level, that valve opens. This allows dry blend to fall from the storage bin to the active bin. It closes when the active bin is full. Soon after the valve closes, the blower is activated to convey dry blend from the trailer. This appears to be the time at which flooding occurred. The vacuum in the storage bin during the convey mode probably created vacuum in the feeder as it leaked around the butterfly valve. This probably resulted in fluidization of the material in the feeder bin, making it prone to flooding.

To compound the problem, the dry blend was transferred from the trailer up 42 feet to the storage bin through a 4-in.-diameter line. When the convey cycle shuts off, dry blend in the transfer line falls to the bottom of the line. This dry blend can temporarily plug the transfer line and cause greater vacuum at the onset of the convey mode, which can increase the potential for leakage through the butterfly valve.

To eliminate the flooding of dry blend, plans have been made to install a "bubble-tight" knife gate valve downstream of the butterfly valve. If, in the future, flooding does occur, an emergency shut-off valve to be installed immediately downstream of the feeder discharge will be closed to stop the flooding. This valve would be interlocked with the feeder such that the feeder auger could not turn if the valve were closed.

The pilot-scale test demonstrated the difficulty of handling and metering dry blend. Although the pilot-scale feed system significantly differs from the proposed TGF feeder, we recommend a thorough evaluation of the proposed TGF feed system for flooding potential, as well as thorough testing of the actual TGF feeder.

\subsubsection{High-Level Indicator}

The level sensor for the storage bin (a paddle-wheel type) is mounted on the side of the bin just below the baghouse. The level sensor is used to prevent overfilling of the storage bin. When dry blend reaches the paddle level, it creates enough torque on the paddle to stop the device from 
turning. When the paddle stops, it sends a signal to the feeder controller to stop conveying dry material. During the test, the paddle wheel would occasionally stick, in which case the control system was given a false "full" signal and would not call for a transfer of dry blend from the trailer.

This problem was discovered when the active feed bin would only partially fill during a reload period. The faulty level sensor caused five short production interruptions, none of which required flushing of the grout-filled equipment. Based on this experience, the paddle wheel sensor cannot be recommended for the TGE application.

Alternative means of level sensing in the TGF dry blend feed system should be considered, e.g., load cells, capacitance methods, and vibrating level sensors. In subsequent tests of the pilot-scale process, plans have been made \pm 0 replace the paddle-wheel level sensor with a vibrating level sensor. These vibrating sensors have been used extensively in dusty environments, specifically in fly ash and cement applications.

\subsubsection{Bin Vibrator}

A vibrator on the storage bin was used to promote the transfer of dry blend from the storage bin into the active bin during a reload period. Occasionally the vibrator seized. Without the vibrator, the transfer of dry blend from the storage bin to the active bin was slow. It is desirable to fill the active bin rapidly to reduce the amount of time the feeder remains in a volumetric mode. Normally the feeder is operated in the gravimetric mode, which provides better control of the mix ratio.

The air to the vibrator was filtered but was not lubricated. To improve future performance, an oiler has been installed in the air supply line to the vibrator. A redundant vibrator will also be installed.

\subsubsection{Vibrating Screen}

A vibratory screen was installed upstream of the pilot-scale mixer to prevent oversized particles from entering and possibly damaging the mixer and the grout pump. During the pilot-scale test, the effluent from the vibrating screen was periodically weighed to determine the efficiency of the DMRHF in screening oversize particles. During 10 hours of grout production, 0.3 wt\% 
(0.5 vol\%) of oversize particles was collected. Such weighing verifies that the DMRHF produces an acceptable dry blend for TGF operations.

\subsubsection{Mixer}

In general, the grout mixer performed very well. The following discussion analyzes the problems that occurred because of the dry blend flooding, the substantial dust generation, and the wear that was observed on a few of the mixer blades.

\subsubsection{Dry Blend Flooding}

At the start of the test, the discharge gate on the mixer was about $25 \%$ open to reduce dust generation from the mixer. When major flooding occurred, very thick grout and lumps of unwetted dry blend were produced. This overly thick grout caused a high torque on the mixer, which resulted in two shear pin failures. The mixer was cleaned out, the shear pin was replaced, and the test was restarted. The mixer shear pin is designed to fail at 20,000 in./1b, before significant damage to the mixer can occur. The TGE mixer will use motor heaters instead of shear pins to prevent damage to the mixer.

As discussed in Section 4.5.1.1, the operators learned to avoid shear pin failure by reducing the dry-blend feed rate when thicker grout was observed and by stopping the mixer if thick grout continued to be produced.

When the mixer was flooded with dry blend, it was necessary to remove the mixer cover and manually remove the dry blend and thick grout. Such actions are not feasible in the TGE mixing module; therefore, reliable performance of the feed system is essential. Remote online viscometry at the TGE surge tank or other instrumentation at the feeder discharge might provide additional assurance that the TGE feed system is operating properly.

\subsubsection{Dust Generation}

Significant generation of dust occurred during the pilot-scale test. This magnitude of dusting had not been observed in previous tests when the vibrating screen directly upstream of the mixer was not in service. In the May, 1986 test, dusting was eliminated by partially closing the discharge gate on the mixer ( $75 \%$ closed). Because of the dry blend flooding during the pilot-scale 
test, a decision to keep the discharge gate fully open was made early into the test. A fully open gate was believed to be more capable of passing the thick grout produced during a flooding incident without plugging.

Dusting in the TGE mixer will be controlled by venting the surge tank to a filter system. Because of the potential for plugging, the use of the discharge gate is not recommended to control dust generation. Therefore, dust generated at the pilot-scale mixer in future tests will be exhausted by fans.

\subsubsection{Equipment Wear}

The screws and paddle blades immediately downstream of the dry-blend inlet port on the mixer showed some wear. A relatively thick coating of grout was observed on the top of the mixer lid where the blades passed. This grout layer is believed to be both the cause and result of wear observed on the screw and paddle blades. The grout layer would gradually increase in thickness as the blades wore away.

The top of the screw blade eroded about 0.05 inch and the top of the paddle blade eroded about 0.2 inch. Figure 4.19 depicts the amount and location of the erosion on the blades. The blades in the pilot-scale mixer are made of 316 stainless steel. More frequent mixer flushes might have reduced the amount of wear observed. To reduce wear, stellite tips on the blades are recommended for the TGE mixer.

\subsubsection{Mixer Efficiency}

The grout mixer is intended to mix the dry blend and liquid waste, producing a very homogeneous slurry with a minimal amount of nondispersed particles. Mixer efficiency tests were performed during every 2 hours of grout production. A known volume of sample from the mixer discharge was poured onto a No. 30 screen. Water was gently run over the grout to wash away the slurry. The remaining particles were placed in a beaker and dried. After one day, the dry solids were weighed. The weight of the solids was divided by the volume of slurry to calculate mixer efficiency. The values of 11 mixer efficiency tests ranged between 0.56 grams of solids per liter of grout to 1.5 grams per liter $(0.74-2.0$ vol\%). The average value was 0.96 grams per liter with a standard deviation of 0.33 . 


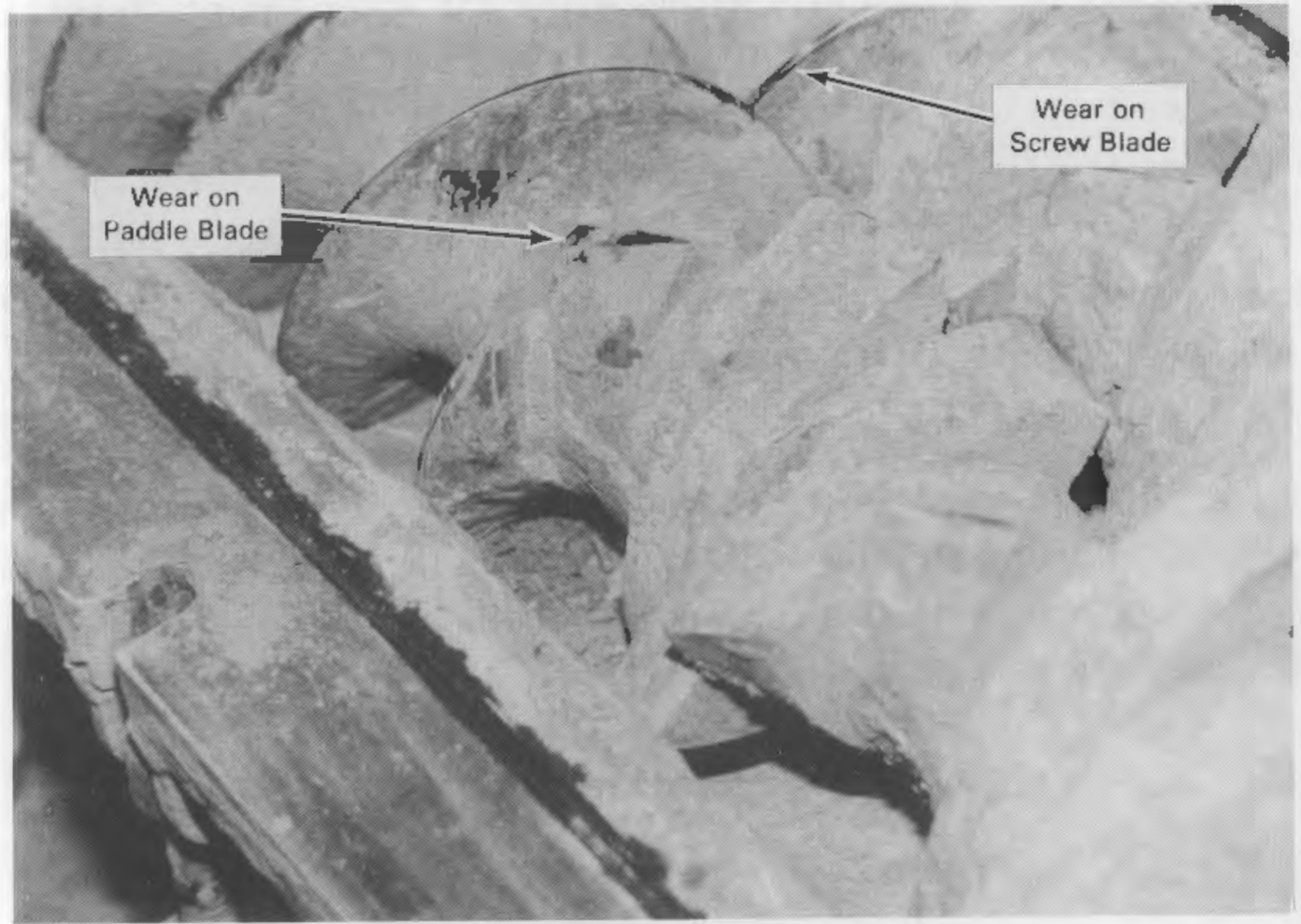

FIGURE 4.19. Wear on the Screw and Paddle Blade

In recent laboratory tests conducted at PNL to measure the effect of unmixed dry particles in grout, insignificant effects were found at dry particle levels up to 4 vol\% $(30 \mathrm{~g} / \mathrm{L})$. It is likely that the amount of unmixed particles in the grout is more a function of the quality of the dry blend than of the effectiveness of the mixer. In any case, dry blend from the DMRHF and the pilot-scale mixer produce grout of acceptable particle content. The same is expected of the TGE mixer.

\subsubsection{Pump}

The progressive cavity pump performed satisfactorily. Prior to the test, a new stator had been installed; the pump with the new stator was calibrated with water before and after the test. This subsection presents the results of the calibrations and a discussion of the stator appearance after the test. 


\subsubsection{Pump Calibrations}

The pump was calibrated with water before and after the pilot-scale test to determine the wear on the stator after 24 hours of grout production. Results of the tests are presented in Figure 4.20. At $350 \mathrm{rpm}$ and at 2 psi pressure head, the flow rate through the pump with the new stator was $15.5 \mathrm{gpm}$; the flow rate after 24 hours of grout production was $16.1 \mathrm{gpm}$. The difference in the flow rates is near the accuracy of the calibration method. Therefore, it is concluded that the stator experienced negligible wear.

Although minimal wear of the stator occurred in the pilot-scale test, results cannot be extrapolated with confidence to the TGE grout pump because pressures during TGE processing will be greater. The absence of a decline in performance over the 24-hr period of grout production is a positive indication that TGE pump life will be acceptable.

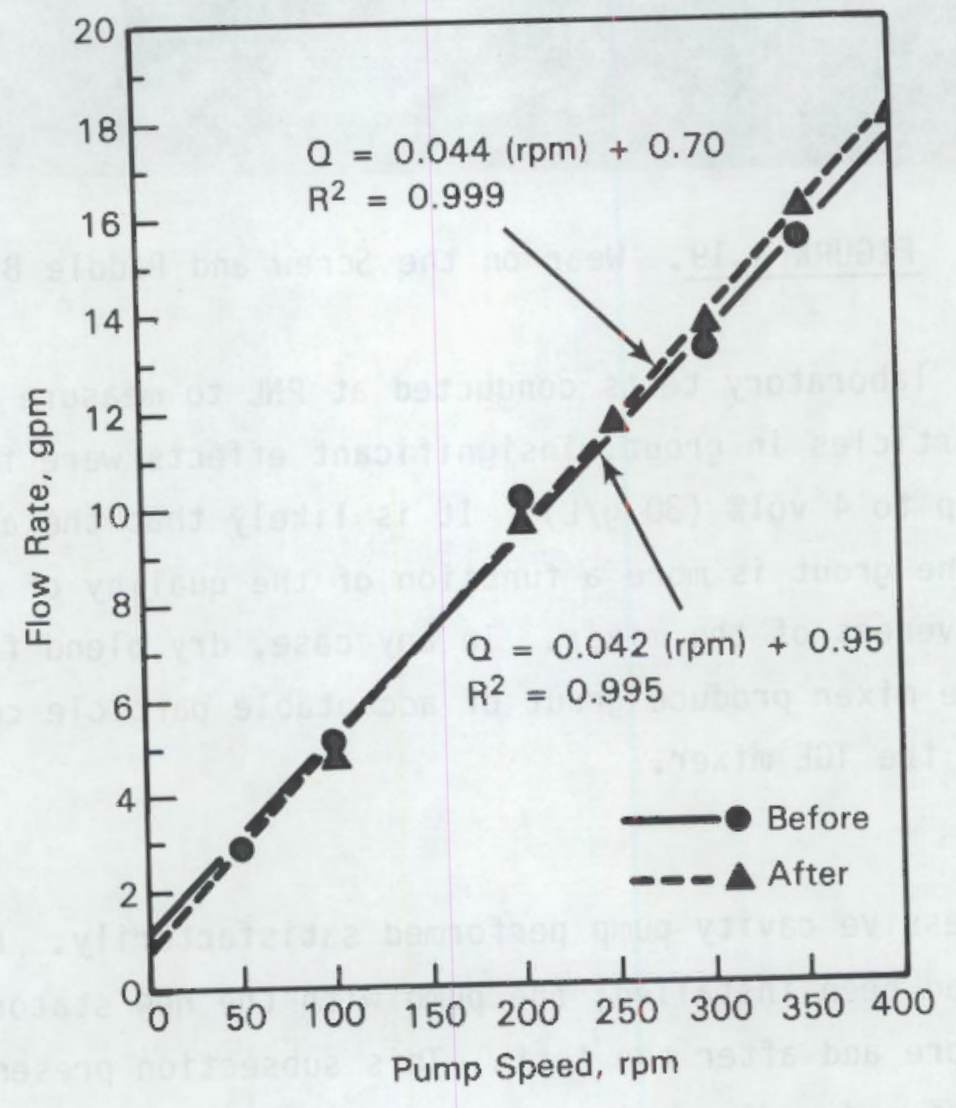

FIGURE 4.20. Pump Calibrations Before and After the Pilot-Scale Test 


\subsubsection{Stator Appearance}

After the pilot-scale test, the pump stator was examined. Several circumferential delaminations, approximately 0.75 inch long and 1 inch deep, were observed in the discharge end of the stator. As of this writing, the stator has not been dissected to determine if delaminations are present inside the stator. Delaminations are not expected to occur in the TGF grout pump if a top-of-the-line stator is used.

\subsubsection{STurry Instrumentation}

Process instrumentation for slurries in the pilot-scale test included the PSW flowmeter, the grout flowmeter, and grout pressure sensor. In earlier tests, a grout level detector in the surge tank was examined. All of the instruments performed satisfactorily except for the level detector in the surge tank. In this section, the performance of the process instruments for slurries is discussed.

\subsubsection{PSW Flowmeter}

The PSW flow rate was indicated by a rotometer and a magnetic flowmeter; the datalogger recorded the reading from the magnetic flowmeter. No problems were encountered with this system. A magnetic flowmeter with remote electronics to indicate the flowrate of radioactive LLW should perform satisfactorily in the TGF.

\subsubsection{Grout Flowmeter}

The grout flow rate was also measured with a magnetic flowmeter. The flowmeter performed satisfactorily, thus a magnetic flowmeter should also be acceptable for measuring grout flow rate in the piping to the vault.

\subsubsection{Level Sensor in Surge Tank}

The level sensor in the surge tank, a capacitance-type point sensor, was located near the bottom of the tank. The purpose of the level sensor is to warn the operator when the level of grout in the surge tank is low.

In prior tests, grout buildup on the sensor prevented the sensor from working properly. As a result, careful visual attention to the level of grout 
in the surge tank was required by the operator at all times. Based on this experience, a capacitance level sensor is not recommended for the TGE surge tank.

\subsubsection{Grout Pressure Sensor}

The grout pressure sensor (a diaphragm type) was located immediately downstream of the pump discharge. The sensor worked satisfactority and is recommended for use in the piping to the vault. The pressure sensor is designed with a smooth, round surface so that flow is not restricted. Also, there are no stagnant areas where grout can build up and possibly plug the sensor.

In choosing a suitable pressure sensor for the TGE, several factors should be considered: 1) the effect of the level of radiation on the life of the material that contacts the grout and any fluid in the sensor, 2) the wear rate of the material that contacts the grout, and 3) possible dead spots where grout could build up and possibly plug the line. The type of sensor used in the pilot-scale test should be acceptable for at least low-dose waste.

\subsubsection{Trench}

A splash pad of 60-mil high-density polyethylene (HDPE) was placed directly below the discharge nozzle on top of the trench liner. To keep it in place, one corner of the pad was anchored with a steel plate. The splash pad was installed to protect the liner from possible abrasion due to splashing grout.

Although it is planned to recover and examine the splash pad when the monolith is exhumed, it is doubtful that conclusions can be extrapolated to a similar splash pad for the disposal vault, where grout will fall 35 feet to the vault floor. Therefore, a conservative design for the vault splash pad is recommended, e.g., a concrete or steel pad.

The trench cover performed as designed. The polyvinyl chloride (PVC) vapor barrier was effective in containing the moisture in the trench. The wood under the cover released some components onto the grout surface as evidenced by discoloration of grout directly under some of the joists. Cured grout properties will not be impacted because grout samples for analysis were kept 
isolated by the PNL core sampler. It is possible that minor contamination of the separated liquid may have occurred, however.

Because the cover for the pilot-scale test bears no resemblance to a vault cover, no appropriate conclusions regarding the cover can be extrapolated to the vault design.

The discharge nozzle was merely an unrestricted opening of the 1-in. delivery pipe. The "nozzle" performed well; no spraying was observed as grout was discharged from the nozzle. Based on this experience, the open-pipe nozzle design appears acceptable for the vault application. 


\subsection{CONCLUSIONS AND RECOMMENDATIONS}

\subsection{CONCLUSIONS}

The objectives of the pilot-scale test performed on July 29 and 30,1986 , were successfully met. Data taken during and after the test were used to assess equipment performance and to evaluate grout behavior inder conditions that closely approximate those expected in a vault. Nearly 600 samples of simulated PSW, dry blend, grout, and separated liquid were collected as specified in the test sampling plan. Several significant conclusions were drawn:

- The adiabatic temperature rise of a similar grout will be at least $37^{\circ} \mathrm{C}$, and probably higher. The temperature rise of grout must be considered to ensure that the maximum grout temperatures do not exceed the evolving criteria.

- The maximum flow angle of PSW grout in a vault is not expected to exceed $3^{\circ}$ for grouts with similar rheological properties. The average flow angle is not expected to exceed $2^{\circ}$.

- Separated liquid that forms on the surface of grout in a vault will probably be totally absorbed by the grout within 40 days after the termination of grout production, provided that the flush water pumped to the vault does not exceed $0.4 \%$ of the grout volume.

- The grout set within 2 days at all surface locations inspected. The faster-than-expected setting rate can be attributed to the accelerating effect of the relatively high temperatures achieved in the monolith. Similar setting rates can be expected in the vaults.

- Data collected during the pilot-scale tests show that the dry blend from the DMRHF has an insignificant amount of oversized particles.

- The pilot-scale grout mixer and pump, which are similar to those planned for the TGE, performed satisfactorily, as did most other components of the pilot-scale process. It is believed that 
relatively minor changes in the process design are required to ensure reliable operations. Consequently, the TGF should also be capable of satisfactory operation.

- The degree of cracking of grout in the trench was minimal, reducing concern about how cracking would affect the performance assessment of this disposal method. (Cracking of a monolith creates additional surface area, which can lead to increased release of contaminants from the monolith.)

\subsection{RECOMMENDATIONS}

The results of the pilot-scale test indicate a need for additional analyses. Suggestions for the TGE design and modifications to the pilotscale equipment are also provided.

\subsubsection{Further Analyses}

- Additional tests should be performed to determine the maximum temperature rise expected in the vaults.

- A study of grout mixing methods in the laboratory should be performed in conjunction with a pilot-scale test to establish a laboratory mixing procedure that yields grout that satisfactorily simulates grout produced with the pilot-scale equipment. This procedure would be used at the TGF with actual waste samples to verify grout processability and other properties prior to grouting specific batches of actual wastes (planned for FY 1987).

- An experiment using a grout pump and piping similar to the TGF equipment should be performed to determine the amount of shear thickening expected in piping to the vault (planned for Fy 1987).

- A critical Reynolds number of 2600 should be used for more realistic calculations of critical flow rates of grout (Section 4.3 .11 ). 


\subsubsection{Transportable Grout Facility}

- Due to the flooding problems and consequences experienced in the pilot scale test, the TGF dry-blend feed system should be thoroughly evaluated for flooding potential. The TGF dry-blend feed system should also be tested under a variety of upset conditions before operation with actual radioactive grouts.

- The bearing housing on the discharge end of the grout mixer should be sealed to prevent bearing damage and/or contamination by grout.

- The TGF piping should be flushed with water at a Reynolds number greater than 10,000. Approximately three pipe volumes of clear water per flush should be used.

- An analysis of the impact of the shear imparted by the proposed TGE surge tank agitator on the grout should be performed.

- Paddle-wheel level sensors are not recommended in dusty environments; other level sensing devices should be considered.

- Stellite tips for the TGE mixer impellors are recommended to reduce wear.

- Capacitance level sensors in the grout surge tank of similar design to those used in the pilot-scale test are not recommended unless successfully demonstrated on pilot-scale equipment.

\subsubsection{Pilot-Scale Equipment}

- A bubble-tight knife gate valve will be installed downstream of the butterfly valve at the discharge of the storage bin to provide a better seal. (A poor seal was the suspected cause of dry blend flooding.)

- An emergency shut-off valve will be installed directly downstream of the feeder discharge. This valve will stop dry blend flooding should it occur.

- The paddle wheel high-level sensor in the storage bin will be replaced with vibrating high- and low-level sensors. 
- A lubricator in the air supply line to the storage bin vibrator will be installed to improve vibrator reliability.

- Further development of the mixer flush system should be conducted.

- The bearing housing at the discharge of the mixer will be sealed to prevent grout from entering. 


\subsection{REFERENCES}

American Nuclear Society (ANS). 1984. Measurement of the Leachibility of Solidified Low-Level Radioactive Waste. ANS 16.1, American Nuclear Society, Champaign, Illinois.

American Society for Testing and Materials (ASTM). 1985. 1985 Annual Book of ASTM Standards. American Society for Testing and MateriaTs. Philadzlohia, Pennsylvania.

Dole, L. R. 1985. "Overview of the Applications of Cement-Based Immobilization Technologies Developed at U.S. DOE Facilities," In Proceedings of Waste Management ' 85 Conference, March 1985, Tucson, Arizona.

Fow, C. L., D. McCarthy and G. T. Thornton. 1986. Rheological Evaluation of Simulated Neutralized Current Acid Waste. PNL-5820, Pacific Northwest Laboratory, Richland, Washington.

Lea, F. M. 1971. The Chemistry of Cement and Concrete. Chemical Publishing Co., Inc., New York.

Lokken, R. 0., P. F. C. Martin, W. M. Bowen, H. Harty, and R. L. Treat. 1986. Variability in Properties of Hanford Facilities Waste Grout. PNL-6030, Pacific Northwest Laboratory, Richland, washington.

Mendel, J. E., editor. 1985. Test Methods Submitted for Nuclear Waste Materials Handbook. PNL-3990 Rev, 6, Pacific Northwest Laboratory, Richland, Washington.

Metzner, A. B., and J. C. Reed. 1955. "Flow of Non-Newtonian FluidsCorrelation of the Laminar, Transition, and Turbulent Flow Regions." A. I. Che. J., $1,4,434$.

Smith, D. K. 1976. Cementing. American Institute of Mining, Metaliurgica?, and Petroleum Engineers. Dallas, Texas.

State of Washington Department of Ecology (WDOE). 1984. "Chemical Testing Methods for Complying with the Dangerous Waste Regulation, "Chapter 173-303, Washington Administrative Code, State of Washington, 01ympia, Washington.

U.S. Environmental Protection Agency (U.S. EPA). 1982. "Test Methods for the Evaluation of Solid Waste." Physical/Chemical Properties. SW-846. GP0

Stock No. 055-002-8100-2. Washington, 0.C.

U.S. Environmental Protection Agency (U.S. EPA). 1986. Proposed Rule: Hazardous Waste Management System: Land Disposal Restrictions," Code of Federal Regulations, Volume 40 , parts $200,261,267,264,265,26 \overline{8}, \overline{270}$, and 271. Federal Register 51:9 (January 14, 1986), U.S. Environmental Protection Agency, Washington, D.C. 

No. of

Copies

OFFSITE

30 DOE Technical Information Center

3 DoE Office of Defense Waste \& Transportation Management GTN Washington, DC 20545

ATTN: T. C. Chee, DP-123 G. H. Daly, DP-124 J. E. Lytle, DP-12

2 DUE Office of Remedial Action and Waste Technology GTN Washinyton, DC 20545

ATTN: J. A. Coleman, NE-25

T. W. Mcintosh, NE-25

A. T. Clark

Division of Fuel Material Safety

Nuclear Regulatory Commission

Washington, DC 20555

V. Stello

Office of the Executive Director for Operations

Mail Station 6209

Nuclear Regulatory Commission Washington, DC 20555

G. L. Sjoblom

Environmental Protection Agency

Office of Radiation Programs

401 M Street, S.W.

Washington, DC 20460

J. M. McGough

DOE Albuquerque Operations uffice

P.0. Box 5400

Albuquerque, NM 87185
No. of
Copies

E. Maestas

DOE West Valley Operations Office

P.0. Box 191

West Valley, NY 14171

2 DOE Idaho Dperations Office

550 Second Street

Idaho Fails, ID 83401

ATTN: J. P. Hamric

S. T. Hinschberger

F. T. Fong

DOE San Francisco operations

1333 Broadway

Oakland, CA 94612

M. R. Jugan

DOE Oak Ridge Operations Office

P.0. Box E

Oak Ridye, TN 37830

W. J. Brumley

DOE Savannah River Operations office

P. 0. Box A

Aiken, SC 29801

M. J. Steindler

Argonne National Laboratory

9700 South Cass Avenue

Argonne, IL 50439

C. S. Abrams

Argonne National Laboratory

P.0. Box 2528

Idaho Falls, In 83401

3 Battelle Memorial Institute

Project Management Division

$505 \mathrm{King}$ Avenue

Columbus, OH 43201

ATTN: W. A. Carbeiner

W. S. Madia

Tecnnical Library 
No. of

Copies

L. D. Ramspott

Lawrence Livermore National Laboratory

University of California

P.0. Box 808

Livermore, CA 94550

D. T. Uakley, MS 671

Los Alamos Scientific Laboratory

P.0. Box 1663

Los Alamos, NM 87544

2 Oak Ridge National Laboratory

P.0. Box $Y$

Oak Ridge, TN 37830

ATTN: E. W. MCDaniel

T. L. Sams

4 Sandia Laboratories

P.0. Box 5800)

Albuquerque, NM 87185

ATTN: D. R. Anderson

R. W. Lynch

W. Weart

Technical Library

J. R. Berreth

Westinyhouse Idaho Nuclear

Co., Inc.

P.0. Box 4000

Idaho Falls, ID 83401

4 E. I. du Pont de Nemours

\& Company, Inc.

Savannah River Laboratory

Aiken, SC 29801

ATTN: R. L. Hooker

C. A. Langton

H. F. Sturm, Jr.

E. Wilhite

E. A. Jennrich

EG\&G Idaho

P.0. Box 1625

Idaho Falls, IO 83415
No. of

Copies

R. Shaw

Electric Power Research

Inst i tute

3412 Hillview Avenue

P.0. Box 10412

Palo Alto, CA 94304

3 West Valley Nuclear Services Company

P.0. Box 191

West Valley, NY 14171

ATTN: J. C. Cwynar

S. J. Marchetti

J. M. Pope

J. L. White

Energy Research \& Development Authority

Empire State Plaza

Albany, NY 127.23

ONSITE

5 DOE Richland Operations Office

G. J. Bracken

R. E. Gerton

R. D. Izatt

J. D. White

E. M. Bowers

29 Rockwell Hanford Operations

J. M. Allison

T. B. Bergman

D. 0. Bowers

L. C. Brown

M. L. Carrigan

B. H. Gilbert

R. H. Guymon

J. D. Herb

S. M. Peterman

R. D. Prosser

J. F. Rjddelle

A. R. Tedeschi

J. E. VanBeek

L. D. Vanselow

T. B. Venziano 
No. of

Copies

G. F. Williamson

D. D. Wodrich

R. D. Wojtasek

D. E. Wood

J. J. Zimmer

1 Westinghouse Hanford Company

R. E. Lerch

37 Pacific Northwest Laboratory

W. W. Ballard, ur.

W. F. Bonner

T. T. Claudson

D. G. Coles

W. T. Farris

C. L. Fow

M. S. Hanson

D. G. Huizenga

C. R. Hymas

D. A. Lamar

R. U. Lokken

P. F. C. Martin

D. Mccarthy

J. L. †AElroy

A. H. McMakin

G. B. Meliinger

b. H. Mitchell (10)

R. J. Serne

G. H. Sewart

L. E. Thompson

R. L. Treat

Publishing Coordination (2)

Technical Report Files (5) 
$+$

$\vdots$ 